\title{
Constitutional Amendments and the Consolidation of the Rule of Law in Democratizing Francophone West Africa: Case Study of Benin, Burkina Faso, and Senegal
}

\author{
Bagnini Kohoun
}

Follow this and additional works at: https://researchrepository.wvu.edu/etd

\section{Recommended Citation}

Kohoun, Bagnini, "Constitutional Amendments and the Consolidation of the Rule of Law in Democratizing Francophone West Africa: Case Study of Benin, Burkina Faso, and Senegal" (2014). Graduate Theses, Dissertations, and Problem Reports. 6000.

https://researchrepository.wvu.edu/etd/6000

This Dissertation is protected by copyright and/or related rights. It has been brought to you by the The Research Repository @WVU with permission from the rights-holder(s). You are free to use this Dissertation in any way that is permitted by the copyright and related rights legislation that applies to your use. For other uses you must obtain permission from the rights-holder(s) directly, unless additional rights are indicated by a Creative Commons license in the record and/ or on the work itself. This Dissertation has been accepted for inclusion in WVU Graduate Theses, Dissertations, and Problem Reports collection by an authorized administrator of The Research Repository @ WVU.

For more information, please contact researchrepository@mail.wvu.edu. 
Constitutional Amendments and the Consolidation of the Rule of Law in Democratizing Francophone West Africa: Case Study of Benin, Burkina Faso, and Senegal.

\author{
Bagnini Kohoun \\ Dissertation submitted to the \\ Eberly College of Arts and Sciences at \\ West Virginia University \\ in partial fulfillment of the requirements \\ for the degree of \\ Doctor of Philosophy \\ in \\ Political Science \\ John Kilwein, Ph.D., Chair \\ Karleen West, Ph.D. \\ Philip A. Michelbach, Ph.D. \\ Janice S. Spleth, Ph.D. \\ Neil B. Berch, Ph.D. \\ Department of Political Science \\ Morgantown, West Virginia \\ 2014
}

Keywords: Constitution-making, Non-consolidating Constitutional Amendments, democracy, the rule of law, Francophone West Africa, Judicial Independence

Copyright 2014 Bagnini Kohoun 


\begin{abstract}
Constitutional Amendments and the Consolidation of the Rule of Law in Democratizing Francophone West Africa: Case Study of Benin, Burkina Faso, and Senegal.

Bagnini Kohoun

Constitutional stability is usually perceived as an invaluable asset in democratic regimes. Constitutional amendments become suspicious when they occur too often, particularly in countries newly engaged in the democratic process. This dissertation argues that recent constitutional amendments in democratizing Francophone West African countries are not necessarily made to advance democracy or the rule of law. Instead, they are designed to reinforce the political agenda of incumbent power-holders. Using a case study of three Francophone African countries (Benin, Burkina Faso, and Senegal), I try to understand why there are so many constitutional amendments in so short a period of time in these fragile democratic countries. Is this phenomenon of frequent constitutional amendment due to the nature of these countries' constitutions that are made too easy to amend? Is it rather due to the weakness of the opposition parties and civil society, or can the phenomenon be explained by the absence of judicial independence, due to an overshadowing of other branches of the government by the executive power?
\end{abstract}


Dedication

To my parents: Nonyèza Kohoun and Moussahan Fofana 
Acknowledgements

First, I would like to thank my dissertation committee for all of your time and contributions to this project. Dr. John Kilwein, Dr. Karleen West, Dr. Philip A. Michelbach, Dr. Janice S. Spleth, Dr. Neil B. Berch.

Thank you, Dr. Kilwein for believing in this project from the beginning. Thank you for your invaluable guidance through the development of this work, and for everything that you have done to help me keep my graduate assistantship until I am done writing this dissertation.

I want to especially express my gratitude to Dr. West for all of the guidance and expertise that you have provided throughout this whole process. I could not have done it without you.

To Dr. Spleth, I would like to say that this note of thanks does not do justice to the amount of gratitude I feel towards you for everything you have done for me. You read this entire dissertation multiples times and provided me with invaluable comments to make my "Franglish" understandable to others. You kept your office's doors always open to me whenever I needed help.

Thank you Dr. Michelbach for your willingness to serve on my committee and for providing me with the first article that served as a jump starter for me when I was stuck. Thank you for your willingness to participate from oversees to my dissertation defense.

Thank you, Dr. Berch for your willingness to serve on my committee and for the guidance and advice you have provided.

Thank you Dr. Loada G. Augustin for your willingness to participate in my dissertation project as an adviser and for all the great contributions you have provided.

My Deepest thank to Ms. Jennifer McIntosh and the President's Office for Social Justice (The Division of Diversity, Equity, and Inclusion) for the financial support to this project. Jennifer, my "American mother", I mean my "Jamerican mother" as you would prefer, you were known to us (Minority Doctoral Students) not as the Executive director of the President's Office for Social Justice, but as our mother who was always there to provide us with all kinds of supports. I will always be grateful to you. I could not have completed this dissertation without your invaluable support.

Thank you to my friend Jacob Sanwidi for your personal contribution to the success of this dissertation.

Thank you to Yaning Mao, my "Chinese-African friend", for your personal support to this project.

Thank you to my Burkinabe family in Morgantown (the Sanwidis, Rouambas, and the Tougmas) for your moral support.

Finally, I want to thank my Doctoral cohort colleagues and Friends - Saffa Lamine, Kombe Kapatamoyo, Timothy Addai Balag'kutu Adivilah, Ellen Belchior Rodrigues. Thank you for your camaraderie. 


\section{Table of Contents}

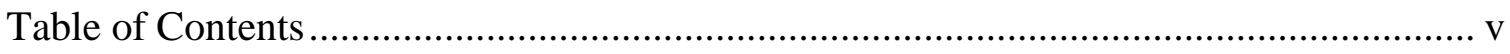

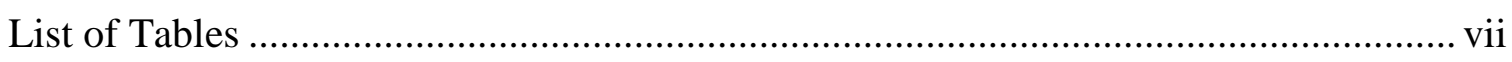

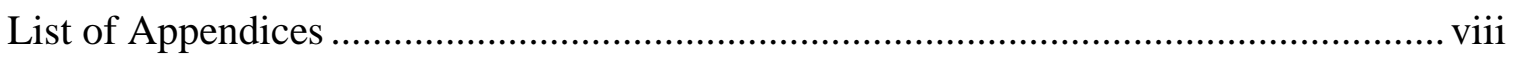

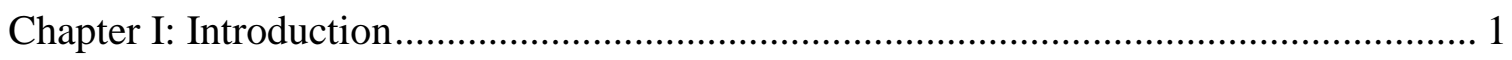

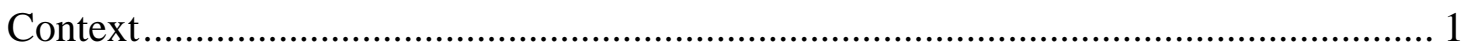

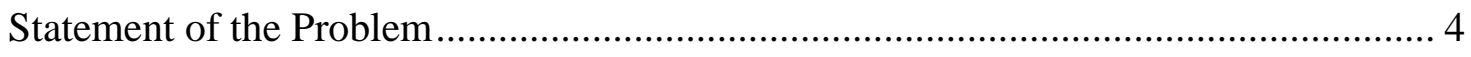

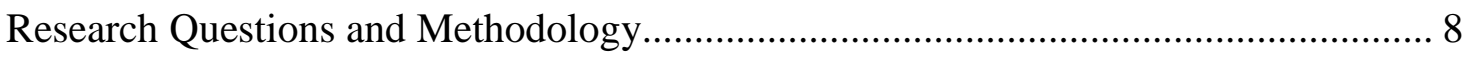

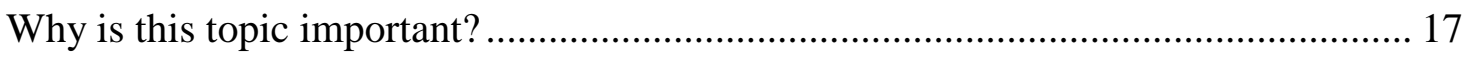

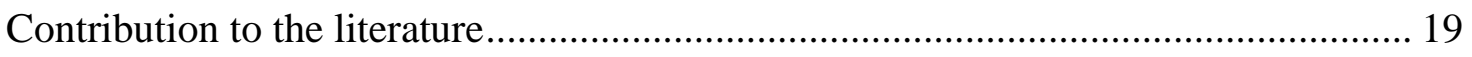

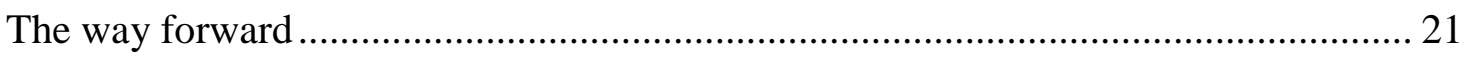

Chapter II: Literature on the constitutional amendment process ................................. 25

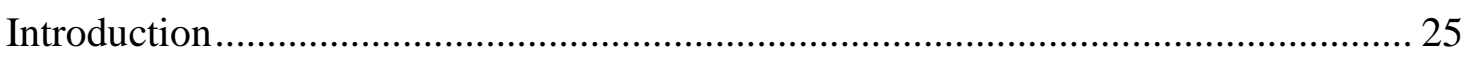

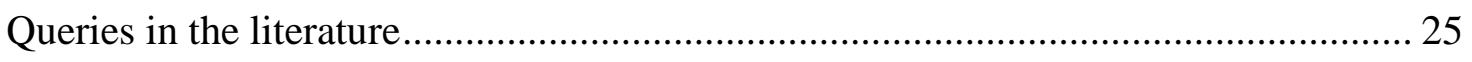

The ways constitutional amendments happen...................................................... 30

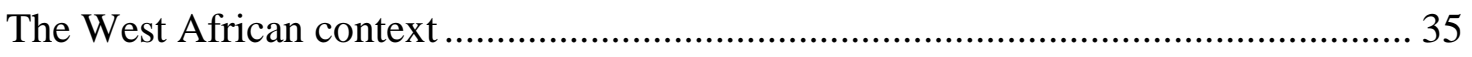

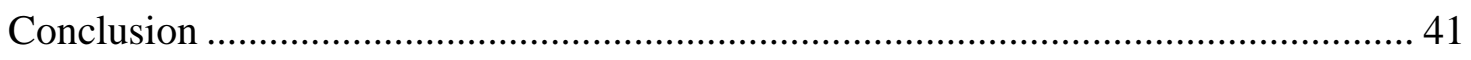

Chapter III: Non-consolidating constitutional amendments ....................................... 43

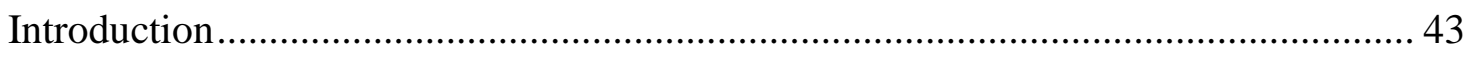

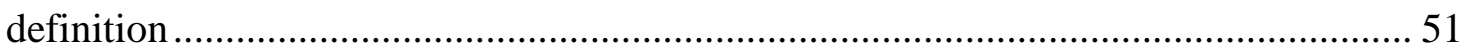

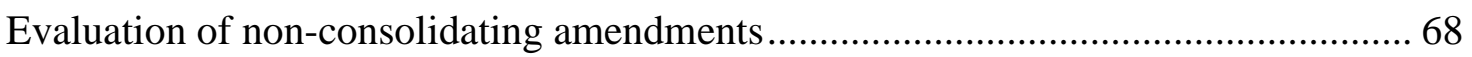

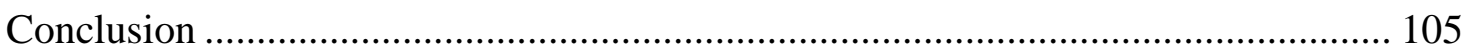

Chapter IV: Openness of constitutional adoption process .......................................... 108

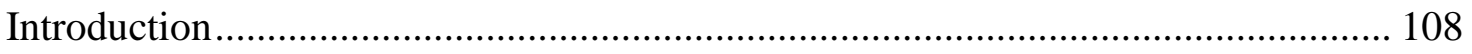

Diversity of participants in constitutional drafting ........................................... 110

Information and transparency of the process ..................................................... 123

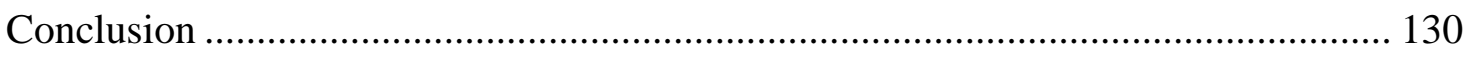

Chapter V: Mechanism of constitutional amendment ............................................. 137

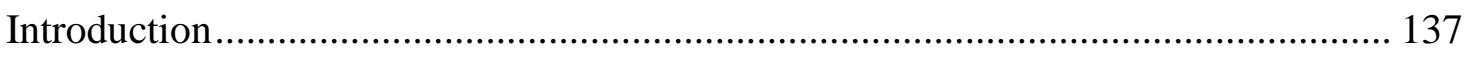

Rigidity of constitutional amendment process.................................................. 138

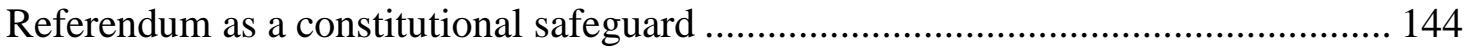

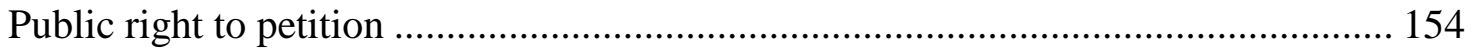

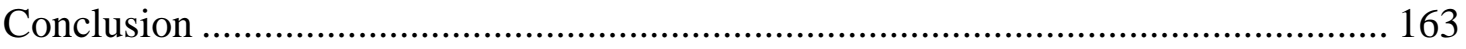

Chapter VI: Independence of the Constitutional Court ............................................. 165 


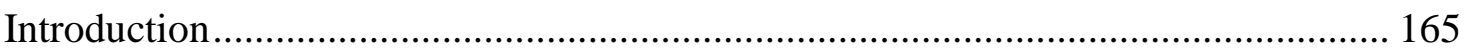

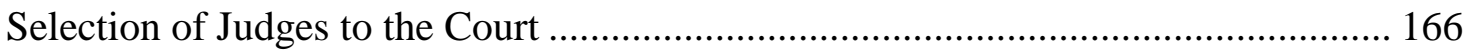

Tenure of Constitutional Judges ........................................................................... 179

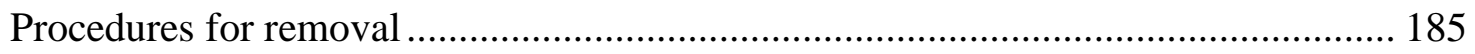

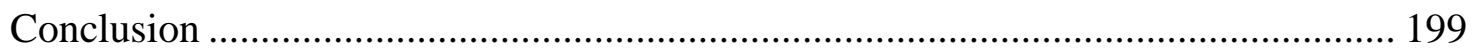

Chapter VII: The implications of non-consolidating amendments in........................... 204

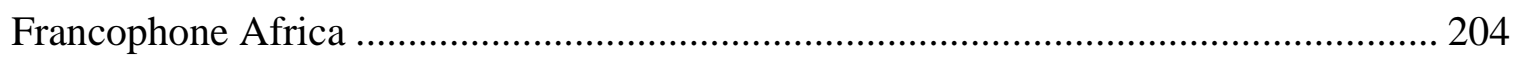

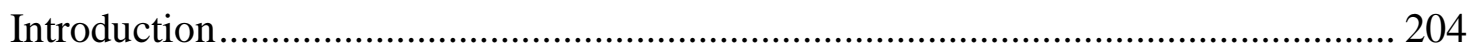

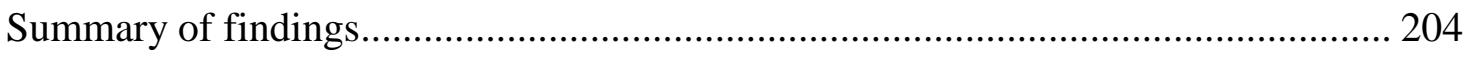

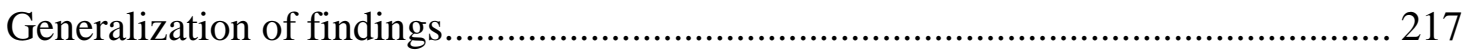

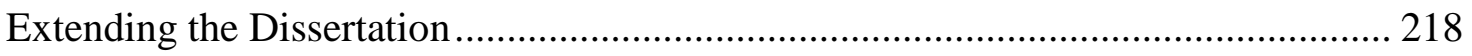

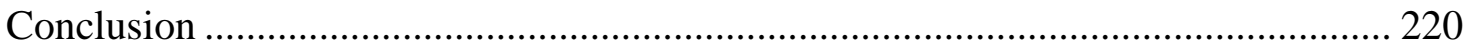

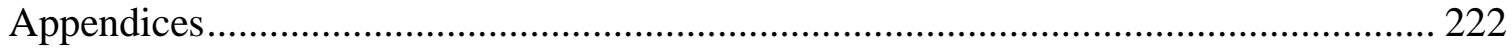

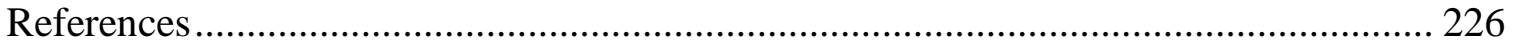




\section{List of Tables}

Table 1: Change of heads of state in Benin since Independence in 1960 .....................

Table 2: Change of heads of state in Burkina Faso since independence in $1960 \ldots \ldots \ldots \ldots . . . .3$

Table 3: Change of heads of state in Senegal since independence in 1960 ...................4

Table 4: identifying a non-consolidating constitutional amendment .......................51

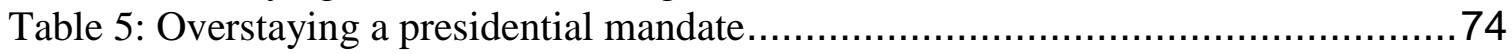

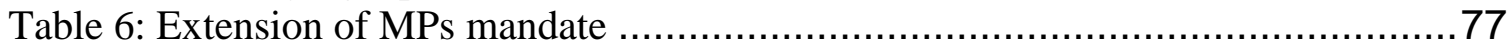

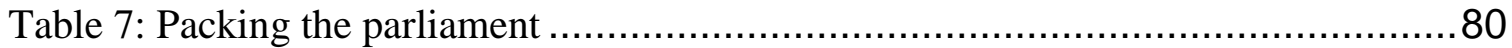

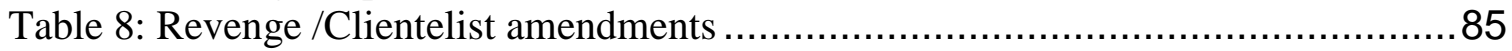

Table 9: Amendments for revenge against the President of the National Assembly.......89

Table 10: Amendments for overstaying a constitutional mandate .............................92

Table 11: Extending the Presidential Mandate ...................................................96

Table 12: Creation of a Vice-Presidency .................................................... 99

Table 13: Summary of non-consolidating aspects of amendments ........................ 104

Table 14: Number and percentage of amendments per country since the adoption of the

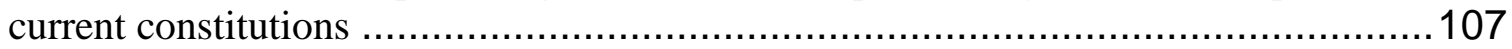

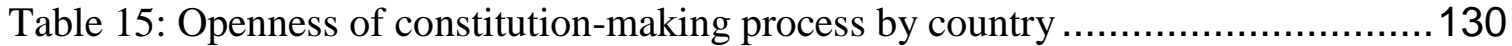

Table 16: comparison of constitutional amendment strategy ...............................158

Table 17: Steps for constitutional amendment .......................................... 162

Table 18: summary of Judges nomination process ....................................... 171 


\section{List of Appendices}

Appendix 1: Votes on constitutional amendments in Burkina Faso

222

Appendix 2: Burkina Faso Constitutional Council opinions and decisions from 1991-

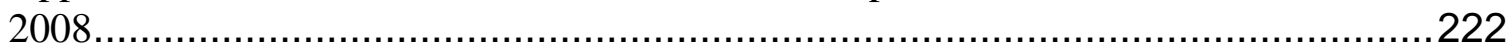

Appendix 3 : First Legislature of Burkina Faso (1992-1997) .................................222

Appendix 4: Second Legislature of Burkina Faso (1997-2002) ..............................223

Appendix 5: Third Legislature of Burkina Faso (2002-2007).................................223

Appendix 6: Fourth Legislature of Burkina Faso (2007-2012) ..............................223

Appendix 7: Fifth Legislature of Burkina Faso ..................................................224

Appendix 8: First legislature of Senegal (2001-2005) .....................................224

Appendix 9: Second Legislature of Senegal (2007-2012).................................225 


\section{Chapter I: Introduction}

\section{Context}

Due to the frequency of military coups d'état since their independence in the 1960s, democratic process was not viewed as the primary mean for access to power in most African countries (Posner \& Young, 2007). With nine different presidents and seven constitutions in its first ten years of independence, the Beninese experience is a good illustration of the instability in Francophone West Africa before 1990 (Fondation Konrad Adenauer, 2009) (see tables 1, 2 and 3 below). In the 1990s, under the pressure of the international community and after what is now known as the historic "Discours de la Baule" in 1990, Francophone African countries entered a period of democratization and adopted new constitutions with the goal of stability and peace for their people through the rule of law.

The La Baule Conference is important for Francophone African countries. After their independence, most of Francophone African countries maintained close relationships with their former colonizer. The newly independent countries needed the international recognition that they could acquire by being close allies with France, a developed and important political power on the world stage. More than any other colonial power, France retained significant influence over Francophone Africa and has in the past helped make or unmake African governments. The context of France's influence over its former colonies is what makes the $1990 \mathrm{La}$ Baule conference such an important moment for African nations and their leaders. The main message that came out of the La Baule conference between France's President François Mitterrand and African leaders was very simple: African autocrats needed to abandon dictatorship and other types of military 
regimes and permanently embrace democracy. It is in the interest of African people to experience regimes that can provide stability and peace through the rule of law.

President Mitterrand's speech came at a crucial moment in world political history: the fall of the Berlin wall in 1989 that served as a premonitory sign for the breakdown of the Soviet Union and the surge of democratization in the developing world. Mitterrand's speech was meant to convince African dictators that the world had changed and that Western powers would no longer offer support to regimes that do not comply with democratic rules. In other words, Mitterrand used the shifting international context to make the point that Francophone Africa needed new constitutions and new democratic regimes to enter the new world of post-Cold War.

After the La Baule conference, West African countries entered the era of democratic regimes and adopted new constitutions. On December 2, 1990, Benin adopted a new constitution following a sovereign conference that emphasized popular participation. In Burkina Faso, the framers received instructions from the party in power on what should be included in the new constitution. The people were presented with the final draft of the constitution for amendment. On June 2, 1991, the Burkina Faso constitution was adopted through a referendum. In Senegal, a committee of five experts was chosen by President Wade to draft the Constitution. The Senegalese people did not take part in the early stage of the process. The opposition parties were presented with the final draft of the constitution for amendment. On January 7, 2001 the final document was adopted through a referendum.

Table 1: Change of heads of state in Benin since Independence in 1960 


\begin{tabular}{|c|c|c|c|}
\hline $\begin{array}{l}\text { Name of the } \\
\text { President }\end{array}$ & Period of mandate & $\begin{array}{l}\text { Length of } \\
\text { mandate }\end{array}$ & $\begin{array}{l}\text { Reason for the end } \\
\text { of mandate }\end{array}$ \\
\hline Hubert MAGA & Dec. 1960- Oct. 1963 & $\begin{array}{l}2 \text { years } 10 \\
\text { months }\end{array}$ & Putsch \\
\hline Christophe SOGLO & Oct. 1963-Jan. 1964 & 4 months & $\begin{array}{l}\text { Lost the } 1964 \\
\text { elections }\end{array}$ \\
\hline M. S. M. APITHY & Jan. 1964. Dec. 1965 & 1 year & Resigned \\
\hline $\begin{array}{l}\text { Congacou } \\
\text { TAHIROU }\end{array}$ & $\begin{array}{l}\text { Dec 1, 1965-Dec 22, } \\
1965\end{array}$ & 22 days & Putsch \\
\hline Christophe SOGLO & Dec. 1965-Dec. 1967 & 2 years & Putsch \\
\hline $\begin{array}{l}\text { Maurice } \\
\text { KOUANDETTE }\end{array}$ & $\begin{array}{l}\text { Dec 18, 1967-Dec. 21, } \\
1967\end{array}$ & 4 days & Deposed \\
\hline Alphonse ALLEY & Dec 1967-July 1968 & 8 months & Deposed \\
\hline Emile Derlin Zinzou & July 1968-Dec 1969 & $\begin{array}{l}1 \text { year six } \\
\text { months }\end{array}$ & Putsch \\
\hline $\begin{array}{l}\text { Paul Emile De } \\
\text { SOUZA }\end{array}$ & Dec. 1969-May 1970 & Six months & Deposed \\
\hline $\begin{array}{l}\text { Presidential council } \\
\text { made of H. MAGA, } \\
\text { J.T. } \\
\text { AHOMADEGBE } \\
\text { and M.S.M. } \\
\text { APITHY }\end{array}$ & May 1970-Oct. 1972 & $\begin{array}{l}2 \text { years and six } \\
\text { months }\end{array}$ & Putsch \\
\hline Mathieu KEREKOU & Oct. 1972-April 1991 & $\begin{array}{l}18 \text { years and } 3 \\
\text { months }\end{array}$ & $\begin{array}{l}\text { Lost the } 1991 \\
\text { elecions }\end{array}$ \\
\hline Nicéphore Soglo & April 1991-April 1996 & 5 years & End of mandate \\
\hline Mathieu KEREKOU & April 1996-April 2001 & 5 years & End of mandate \\
\hline Mathieu KEREKOU & April 2001-April 2006 & 5 years & End of mandate \\
\hline Boni YAYI & \multicolumn{3}{|l|}{ Since April 2006} \\
\hline
\end{tabular}

Table 2: Change of heads of state in Burkina Faso since independence in 1960

\begin{tabular}{|l|l|l|l|}
\hline $\begin{array}{l}\text { Name of the } \\
\text { President }\end{array}$ & $\begin{array}{l}\text { Beginning of } \\
\text { Mandate }\end{array}$ & End of mandate & $\begin{array}{l}\text { Reason for the } \\
\text { end of mandate }\end{array}$ \\
\hline $\begin{array}{l}\text { Maurice } \\
\text { YAMEOGO }\end{array}$ & Dec 11 1959 & Jan 4, 1966 & Popular unrest \\
\hline $\begin{array}{l}\text { Aboubacar S. } \\
\text { LAMIZANA }\end{array}$ & Jan 4, 1966 & Nov 25, 1980 & Coup d'état \\
\hline Saye ZERBO & Nov 25, 1980 & Nov. 7, 1982 & Coup d'état \\
\hline $\begin{array}{l}\text { Jean-Baptiste } \\
\text { OUEDRAOGO }\end{array}$ & Nov. 7, 1982 & August 4, 1983 & Coup d'état \\
\hline $\begin{array}{l}\text { Thomas } \\
\text { SANKARA }\end{array}$ & August 4, 1983 & Oct.15, 1987 & Coup d'état \\
\hline Blaise Compaoré & Since Oct. 15, 1987 & \\
\hline
\end{tabular}


Table 3: Change of heads of state in Senegal since independence in 1960

\begin{tabular}{|l|l|l|l|}
\hline $\begin{array}{l}\text { Name of the } \\
\text { president }\end{array}$ & $\begin{array}{l}\text { Beginning of } \\
\text { mandate }\end{array}$ & End of mandate & $\begin{array}{l}\text { Reason for the end } \\
\text { of mandate }\end{array}$ \\
\hline $\begin{array}{l}\text { Léopold Sédar } \\
\text { Senghor }\end{array}$ & Sep 6, 1960 & Dec.31, 1980 & Resigned \\
\hline Abdou DIOUF & Jan. 1, 1981 & April 1, 2000 & Lost elections \\
\hline Abdoulaye WADE & April 1, 2000 & April 2, 2012 & Lost elections \\
\hline Macky SALL & Since April 2, 2012 & \\
\hline
\end{tabular}

\section{Statement of the Problem}

Twenty years after the new democratic beginnings, many countries passed constitutional amendments that seem to weaken the consolidation of the rule of law in West Africa (Ebeku, 2006; Owona, 1985; Kanté, 1996; Hesseling, 1996). These types of constitutional amendments, called non-consolidating amendments according to the Open Society in West Africa (OSIWA), are what my study focuses on. Non-consolidating amendments, or "Constitutionalisme rédhibitoire" (Owona, 1985), refers to constitutional amendments that do not aim at reinforcing democracy or the rule of law. Instead, they are designed to consolidate the political domination of individuals or a group of individuals through crippling manipulations of democratic rules.

Three examples allow me to develop a better understanding of the concept of nonconsolidating constitutional amendments. On June 2, 1991, the people of Burkina Faso voted by $93 \%$ for a new constitution. Article 37 of that constitution stated, that the President of Burkina Faso was elected for seven years, and that he could be reelected once. In 1997, the article was "undone." It had been amended through legislative process 
and the new version states that the president is elected for five years and that he can be reelected. As we can see, besides the change from seven years to five, what was taken off the initial article is the portion about the limitation of the presidential mandate. In other words, the president can be reelected indefinitely.

One might argue that there is nothing wrong about amending constitutions. After all, constitutions are made to be amended at the right time according to a people's aspirations. Moreover, no constitution is perfect and there should always be room for amendments. However, the problem with Burkina Faso's 1997 Article 37 amendment is neither about the legality of the process nor about the will to make the constitution a better document. The problem has to do with the nature of the amendment. Looking at the particular context of this amendment, one can understand that while the amendment had the approval of all the National Assembly members of the ruling party (CDP), which held more than 80 percent of the 111 members, it lacked legitimacy because the amendment made President Compaoré indefinitely eligible. Changeover of power is part of constitutional democratic principles that prevent one individual from staying in power forever. ${ }^{1}$ Due to African leaders' obsessions with presidency for life, drafters of the 1990s African constitutions designed constitutional provisions to force presidents out of power at a certain period of time. This was done, not only to allow alternation in power, but also to prevent unconventional seizure of power through coups-d'état, for instance. The rationale is that in countries with a weak democratic culture, when a frustrated opposition feels it has no way for ever getting to power, due to the ruling party's unfair manipulations of the democratic game, it might resort to any other means to achieve its

\footnotetext{
${ }^{1}$ This argument will be addressed and clarified in chapter 3 dedicated to non-consolidating constitutional amendments
} 
goal. The eventual consequences are rebellions and instability in Africa. By amending the constitution to allow a sitting president to stay in office, the ruling party has disregarded a constitutional commitment. Actually, it has changed the rules while the democratic game was still ongoing, since President Compaoré was at the end of his second mandate and was set to leave office according to the initial Article 37 of the 1991 Burkina Faso's Constitution.

One important issue that is worth noting is the amendment process. The amendment in the particular case of Article 37 of the Burkina Faso Constitution has been done through legislative process. The literature on constitutions distinguishes three prominent methods of constitutional amendments other than a complete replacement of a Constitution. These three methods are: formal amendment, legislative revision, and judicial interpretation (Lutz, 1994). According to Lutz, the three methods reflect declining degrees of commitment to popular sovereignty.

The point that I am making is that by choosing to amend Burkina Faso's Constitution through legislative process, the government chose to diminish the legitimacy and the degree of commitment to the popular sovereignty of the people of Burkina Faso in order to achieve a particular goal of keeping one person (the president) and his ruling party in power. This particular way of using the constitution to advantage one person or a group of persons is what Fall (2008) calls "instrumentalization" of the constitution with the ultimate goal of preserving power or advantages. Constitutions are also used to block opposition leaders from accessing power. A good illustration of this phenomenon is the case of Alassane Dramane Ouattara, the sitting president of Côte d'Ivoire.

Before 1994, foreigners in Côte d'Ivoire were given the right to vote in city 
elections. ${ }^{2}$ Then an electoral code was introduced to end that privilege. In 2000, Article 35 of the Ivoirian Constitution was introduced to require not only that all presidential candidates be Ivoirian by birth, but that their parents also be Ivoirian (Fall, 2008). Once again, there is nothing wrong with amending a constitution. The problem has to do with the context in which such an amendment happens. In 1990, the former Ivoirian president Houphouet Boigny was visibly ill, and Ivoirians started thinking about who would replace the founding father. Alassane Ouattara, due to his background (an economist who obtained his $\mathrm{Ph} . \mathrm{D}$ in the USA, worked as an associate director for the International Monetary Fund and also served as Prime Minister of Côte d'Ivoire), was viewed as a serious challenger to Henri Konan Bédié, the President of the Ivoirian National Assembly. According to the Ivoirian Constitution as then written, Bédié was to replace President Houphouet Boigny in case of his death and only for the rest of his mandate until a new presidential election could be organized. To prevent the potential danger of losing elections to Alassane Ouattara if he were allowed to be candidate, Bédié introduced an amendment to the constitution requiring that both candidates for the presidential election and their parents be Ivoirians. ${ }^{3}$ At that particular period, there was a debate about the nationality of Ouattara's parents. Some Ivoirians argued that Ouattara's parents were not Ivoirians, but Burkinabé. Ouattara was denied participation as a candidate in the 2000 presidential election by the Constitutional Chamber of the Ivoirian Supreme Court on the grounds that his parents' nationality was doubtful. As described

\footnotetext{
${ }^{2}$ I am referring to Article 25 of October 1985 electoral code that was modified on October 10, 1990.

${ }^{3}$ Before the year 2000, this particular requirement was stated in Article 49 of the Ivorian electoral code voted on December 13, 1994, just a year after the death of President Houphouet Boigny (December 7 , 1993). Precisely because of the timing for the vote of this law, it was criticized by then opposition leader of the Ivorian Popular Front (FPI) Laurent Gbagbo as being unnecessarily xenophobic. The provision was later constitutionalized in 2000 with the passage of Article 35 (Fall, 2008, p. 55).
} 
above, it seems that this particular amendment was aimed at disqualifying Mr. Ouattara from the presidential elections.

In 1992, Prime Minister Koffi Koffigoh of Togo was viewed as a serious challenger by those in power and was prevented from taking part, as a candidate, in the presidential election due to an amendment to the Togolese Constitution that raised the minimum age for presidential candidates to 45 . Koffigoh was 44 years old in 1992. One could argue that the intentions of the amendment were to prevent Koffigoh from competing for power (Fall, 2008, p.59). Otherwise, how can one explain that as Prime Minister of his country, Koffigoh was considered not mature enough for the functions of president, since the raising of the minimum age was based on the assumptions that citizens under age 45 were not mature enough or at least not ready to preside over the destiny of the Togolese people. Many more examples of this kind can be given to show how political leaders in Francophone Africa manipulate constitutions either to directly advance their interests, or to prevent others from getting to power. These are the particular types of amendments called non-consolidating amendments that my study addresses.

\section{Research Questions and Methodology}

Clearly stated, the objective of my study is to explore and understand the emergence of non-consolidating constitutional amendments in Francophone West Africa. Non-consolidating constitutional amendments are amendments that are not intended to reinforce democracy or the rule of law. Instead, non-consolidating amendments are designed to reinforce the political power of an individual or a group through targeted constitutional changes engineered to manipulate electoral and other 
political laws in favor of incumbent power-holders. To determine whether an amendment in question is non-consolidating or not, I analyze the official grounds ${ }^{4}$ for the amendment then I contrast it with conventional principles and practices of constitutional democracy. These conventional principles and practices will be defined in Chapter 3 .

For an amendment to be classified as non-consolidating it must be designed to clearly benefit an individual political actor or group holding power at the time of the amendment's adoption. Amendments that satisfy this criteria usually fail to fit common sense democratic practices known in well-established democracies such as the US and other major Western democracies. Clearly stated, I am looking at constitutional modifications that either prevent incumbent powers from having to face the electorate, e.g., term extensions, or that change the rules of the electoral process to advantage the incumbent powers vis-à-vis their opposition.

Non-consolidating constitutional amendment is the dependent variable that needs to be explained. Actually, this particular political phenomenon raises a major question that begs for answers. Why are Francophone West African leaders inclined to modify constitutions for their own interest? Three research questions help me respond to this question.

1- The Openness of the constitutional adoption process

2- The Mechanism of Constitutional Amendment

3- The Independence of the Constitutional Court By examining my three research questions across countries, I come to the conclusion that the openness of the constitutional adoption process is the most significant factor in

\footnotetext{
${ }^{4}$ The grounds or motivations for an amendment are usually contained in an official document known as "l’exposé des motifs."
} 
explaining the occurrence of non-consolidating constitutional amendments. I suggest that my findings, though with some limitations, can be generalized as they hold truth for other Francophone African countries. For my data sources, I used different sources including, but not limited to: books, dissertations, journals, magazines, newspaper articles, speeches, court cases, the constitutions of the three study case countries and also constitutions of other countries not mentioned, reports of NGOs, and useful websites.

\section{Openness of the Constitutional Adoption Process}

I assume that a more open constitutional adoption process would lead to fewer non-consolidating amendments. In other words, the more transparent and inclusive a constitutional process is, the more thorough and democratic its results would be and the less likely it would be necessary to modify or replace it (Lutz, 1994; Adams, 1980; Morgan, 1988). I argue that the openness of constitutional amendment process as a variable has great explanatory power for the occurrence of non-consolidating constitutional amendments. Actually, the process of constitutional adoption is the foundation of the constitution itself. If a constitution has a strong foundation, it is unlikely to be seriously amended as it would be supported and defended by the people who ratified it (Loada, Fall, \& Badet, 2008). This is what happened in Benin as will be shown in chapter 3.The logic of this reasoning is that in countries where the adoption process is not transparent and inclusive enough, there is no strong and contradictory debate to produce a better quality of the constitutional document. In such conditions, the probability of non-consolidating constitutional amendments occurring is higher, not only because of the quality of the constitution itself, but also because of the indifference people might show toward constitutional issues, leaving the government the freedom to 
engage in any kind of amendments. The question becomes how do I measure the openness of the constitutional adoption process?

I use two indicators to measure the concept of openness: the diversity of the participants and the availability of information during the constitutional adoption period. I define the diversity of participants based not ${ }^{5}$ on how many ethnic groups, religious groups or unions take part to the constitutional adoption processes, but on the concept of consensus. I am interested in knowing whether the adoption process was consensual. I consider to be consensual a constitutional adoption process in which the sitting government reached out to political parties, Unions, religious leaders, civil society organizations, the diaspora...all potential stakeholders and have had them participate in the process from the beginning to the referendum vote of the constitutional draft. To know whether a process was consensual or not, I look at the adoption process in each country. A constitutional document that was drafted entirely by government officials, or the party in power, and submitted to a referendum although it would have been approved, would be classified as non-consensual (Haysom, 2007; Ghai, 2007; Bhattarai \& Subedi, 2007). The commission that participated in the framing of the constitution needs to be as representative as possible of the people in each country. If, for instance, the government and the party in power have a higher number of representatives compared to the opposition parties, the adoption process would be considered unfair and non-consensual.

\footnotetext{
${ }^{5}$ In my three case study countries with 60 or more ethnic groups (Benin and Burkina Faso), around 20 in Senegal, ethnic based political parties are forbidden by constitutional provisions (Article 13 in Burkina Faso, Article 4 in Senegal and Article 5 of the charter for the political parties in Benin). Unlike in Latin America (see Jones, 2008), ethnic political parties are viewed as dangerous for democratizing African countries because of potential clashes that they might create in immature and weak constitutional democratic countries
} 
The indicator about the transparency or the availability of information during the adoption process is an important one. For the population to give their consent to a constitutional document, they need to understand it. Once they understand and vote for it, they would accept and defend it as their own (Haysom, 2007). I measure the availability of information by enumerating and comparing across countries all initiatives taken by the leaders during the transition period to make information available to the public. For an important moment in the life of a country such as the adoption of the constitution, it is common for governments to create a public awareness campaign on constitutional matters (Haysom, 2007; Ghai, 2007). I measure the availability of information to the public by looking at the official transitional documents for any such effort to inform the public on constitutional matters. I assume that the public is not informed once it becomes clear that the transitional government has not had any public awareness campaign plan.

\section{Mechanism of Constitutional Amendment}

The more difficult a constitutional amendment process is, the fewer nonconsolidating amendments a constitution would experience. I argue that the constitutional design each country chooses can allow, slow down, or prevent the emergence of nonconsolidating amendments. I look at three indicators for answers on which one of my three countries' constitutional design is the best fit against the occurrence of nonconsolidating amendments. The three indicators are the following: the rigidity of the constitution; the existence or not of referendum as a constitutional device for direct democracy, and the opportunity or lack of opportunity for public petition as a constitutional device for direct democracy. 
I define the rigidity of the amendment process as the mechanism included in the original constitutional text with the explicit intention of making it harder to amend. ${ }^{6}$ To measure this variable, I consider the steps required for any single amendment with the assumption that the existence of more steps in the adoption process is synonymous with greater rigidity that would limit the number of non-consolidating constitutional amendments or prevent them from happening. This particular idea might look peculiar and even suspicious to a Western analyst of constitutional amendments. It could look even more suspicious to an American scholar. As Lutz (1994) argues, the best constitution is not necessarily the most rigid one. According to Lutz, the U.S. federal constitution is hard to amend, but this does not make it the best constitution in the world. Even though I partially agree with this analysis, I argue, based on the literature on African constitutionalism, that it makes sense to advocate for a rigid constitutional amendment process in the African context where constitutions are easily amended to satisfy particular and egoistic ambitions (Kanté 1996; Hesseling, 1996; Okoth-Ogendo 1996; Hyden 2006; Lindberg 2009; Maltz 2007; Posner and Young, 2007; van de Walle, 2009). The reasoning is that because of the fragile nature of democracy in these countries, constitutional amendments often lead to political instability when constitutions are modified to help incumbent power holders stay in office indefinitely. One needs to keep in mind that in most Francophone democratizing countries, electoral laws and redistricting rules or changes in the number of parliament members are usually not entrenched or made part of constitutions. In addition, incumbent power holders have control over the timing of elections. With all these discretionary powers in their hands, all

\footnotetext{
${ }^{6}$ I will define more extensively the concept of rigid constitution in chapter V.
} 
ingredients seem to be in place for incumbent power holders to have an open-ended free ride to unlimited power, unless the constitution is safeguarded against politically motivated amendments. It is in such a context of an uneven playing field that my suggestion of making constitutional amendments harder makes sense. On this issue, Pascal Lissouba, a former president of the republic of Congo is well-known for his infamous claim that in Africa, one does not organize elections in order to end up being the loser (Kokoroko, 2009).

I suggest that a requirement of a referendum for all constitutional amendments could slow down or prevent the occurrence of non-consolidating amendments. Nonconsolidating amendments often lead to instability or civil wars in certain countries. An illustration of this particular idea is the 2002 civil war in Côte d'Ivoire. Alassane Ouattara, the current president of the country, was prevented from taking part in the 2000 presidential elections by the Ivorian Constitutional Court on the grounds that his parents were not Ivoirians. Although there is no evidence to show that the 2002 war was the immediate result of such political behavior, analysts of Ivoirian politics agree that the dismissal of Ouattara has played an important role in the political turmoil after the death of President Houphouet Boigny (Fall 2011, p.75). Since a referendum is financially costly and may be politically damaging, leaders might think twice before engaging in the process of constitutional amendment if they are required to go through referenda. As constitutional amendment literature suggests, the use of a referendum carries the great advantage of legitimacy (Adams 1980: Morgan 1988). We can measure the use of referendum by looking at each country's initial constitution. 
I argue that the right of the public to petition is an interesting indicator that can play a role in controlling the unwavering will of certain leaders to manipulate the constitution. This constitutional tool gives the ability to the people to put together signatures in order to get the National Assembly to act or to prevent it from action on particular issues. My assumption is that if there is a provision in the constitution that institutes this particular tool as a right for the people, it can be useful in slowing down the zeal of some politicians who want to use the constitution to advance their personal political agenda. The mechanism of constitutional amendment will be further addressed and explained in chapter 5 .

\section{The Independence of the Constitutional Court}

In this chapter, I argue that more independence for the constitutional court would lead to fewer non-consolidating constitutional amendments: however, this can only be achieved when there is fairness in the way judges are appointed. Three indicators are examined in this section in order to clarify what I mean by fairness: judges' appointments, their tenure, and the way they leave office. I measure the fairness of their appointment process by reading the rules about appointments that are included in the initial constitutions of my case study countries. My point is that a constitutional setting in which all members of the constitutional court are appointed by the executive power or by the party in power does not promote judicial independence. One might note that I am focusing my analysis on the constitutional court instead of the judicial system as a whole. The reason is that the Francophone countries included in my study are from the civil law tradition and they do not have one Supreme Court such as in the US. The constitutional court is the institution that solely deals with the constitution and electoral matters. 
Another variable I considered to be a good indicator of the court's independence is judges' terms in office. This variable is important for many reasons. A judge who is nominated for one year might not have the same will or determination to work as one that is chosen for life. Job security is an important factor in developing countries where unemployment is known to be a great issue. I measure the term in office indicator by comparing the rules in the countries included in my study to the conventions existing in old democracies such as in the US.

The indicator concerning the removal of judges is closely related to the one about the term of office even though both processes differ in many ways. I argue that when judges fear for their jobs, they might be inclined to decide in favor of the politicians who hold the power to remove them. I am interested in knowing how easy it is to remove judges from office according to the rules in the countries I study. Constitutional documents and other judicial official documents provide me with information in regards to practices on the issue. I analyze those practices based on constitutional democratic principles (addressed in chapter 3) that are used in established democracies and I decide whether practices in a given country advance judicial independence and the rule of law. This approach might be viewed as unfair since I am analyzing African constitutionalism from a Western perspective. I argue that formal constitutional democracy ${ }^{7}$ is a Western concept and that it is not necessarily wrong to evaluate practices of imported democracy in Africa through Western criteria.

\footnotetext{
${ }^{7}$ By formal constitutional democracy, I mean a system of government in which the power of government is defined and limited based on the fundamental law (constitution) adopted by the people. Constitutional democracy requires the principles of checks and balances and the separation of powers (Akiba, 2004). The notion of the rule of law embodied in constitutional democracy requires that all citizens, including government officials, be subjected equally to the same rules and laws (Marryman \& Pérez-Perdomo, 2007).
} 


\section{Why is this topic important?}

There are three main reasons that make my topic particularly interesting: France's dominance over its former colonies and the La Baule conference of 1990, the distinctiveness of the sovereign conference phenomenon in Francophone Africa, and "the fact that Francophone Africa has been slighted - not to say ignored - in Anglo-American settings"(Clark, 1997 p. 2). First of all, it makes sense to mention that the wave of democratization I refer to in my study did not affect Francophone Africa only. It also affected the English-speaking part of the continent. Actually, my topic addresses a crucial political reality that many African countries (Francophone and Anglophone) now face and that has received few scholars' attention certainly due to the novelty of the phenomenon. My interest, however, in the Francophone part of the continent is due in part to the way the wind of democratization blew in this particular part of Sub-Saharan Africa. $^{8}$

The new constitutionalism and the whole movement of democratization in Francophone Africa have the particularity of being instigated by the 1990 La Baule Conference, which is not the case in Anglophone Africa. Actually, France, more than any other colonial power, has retained close relations with its former colonies and in contrast with the United Kingdom, it is known for making and unmaking African governments (Reynjens, 1991). According to this author, Francophone Africa, compared to Anglophone Africa, has suffered more from bad management and gross human right

\footnotetext{
${ }^{8}$ Although there have also been national conferences in Anglophone Africa (Ethiopia, Somalia, Namibia, South Africa), they haven't had the same importance as in Francophone Africa where Benin with its sovereign conference was seen as a model to follow (Robinson, 1994).
} 
violations from incompetent and corrupt authoritarian regimes. When the opportunity came for democratization, the populations in this part of Africa and also the international community showed some impatience with the status quo. This is the reason why the wave of democratization in Francophone Africa was more spectacular. Of the eighteen Francophone states included in Reynjens's study, fourteen (78 percent) were under a military regime when the wind of democratization started to blow, compared to five (36 percent) countries from the fourteen English-speaking African countries with military regimes for the same period of time. Military regimes in Africa are known for their lack of respect for human rights and their undemocratic governance. Comparing Francophone and Anglophone Africa in terms of their legal inheritance, Joireman (2001) suggests that the English-speaking African countries inherited a better legal system than the Francophone ones. Common law system, according to him, does a better job at providing citizens with the rule of law than does the civil law system. A similar argument is made by Zakaria (1997).

Although, there are striking differences and resemblances between Anglophone and Francophone African countries that deserve to be studied, I find it more interesting to focus my work on Francophone Africa. Besides the French colonial legacy, one important phenomenon that makes Francophone African a good case for my analysis is the phenomenon of national conferences. This new political phenomenon observed in most Francophone countries did not exist to the same degree in Anglophone Africa. National conferences were unique to Francophone countries' new constitutionalism, compared to Anglophone African countries, where democratization happens not through a group movement, but rather through some very diverse forms (Robinson, 1994). 
Among the three countries included in my case study, Benin is the leading example of the success of national conferences in Africa. Moreover, Benin is the only state of the three that has not made any amendments to its 1990 Constitution. The other two countries have different constitutional experiences. In Burkina Faso, there was a presidential election in November 2010. President Compaoré was able to take part in that particular election as a candidate due to an amendment made to the country's Constitution (Article 37). Blaise Compaoré, Burkina Faso's sitting president, has been in power since 1987. In Senegal, a constitutional debate ended up with the Constitutional Council interpreting the law to allow President Wade a third term in office. My topic is an interesting one as it addresses a phenomenon that is part of an ongoing debate in Francophone Africa. This very fact might also be a handicap to the study, since events may change quickly. Another problem that I face in this study is that even though there is some literature about constitutionalism in Africa, there is little work done on the particular topic of non-consolidating constitutional amendments.

\section{Contribution to the literature}

The contribution of my study and its distinctiveness reside in the following facts: while other studies in the literature are concerned with constitutionalism or constitutionmaking in Africa, my study not only includes that part of the argument, but addresses a new phenomenon: the "undoing" process of constitutions (what I refer to as nonconsolidating amendments) in a particular part of Africa that is distinctive by its civil law tradition.

Why study Benin, Burkina Faso, and Senegal in particular? Although historically there is not much difference between these countries and other Francophone West 
African countries, they have the advantage of representing a kind of microcosm of the political reality when it comes to constitutionalism engineering in West Africa (Loada, Fall, \& Badet, 2008). Actually, Benin can be viewed as an outlier in the sense that even though there have been some attempts, its 1990 constitution has never been amended. Moreover, it has successfully implemented a sovereign conference that led to the drafting of its Constitution. Why is Benin then part of my study countries since it has not experienced any constitutional amendment? Let's remember that the ultimate goal of my work is to understand why there are so many constitutional amendments (in so short time) in the early stage of Francophone West African constitutional democratic experience. By choosing to do a comparative study, I needed a case study sample that represents the broad experience of constitutionalism in the region. My challenge was to find a country where there has been no amendments, another country with a moderate experience of amendments, and a third one with more frequency of amendments.

Choosing only countries with constitutional amendment experience would have the disadvantage of excluding counties with no amendments, although those countries are viewed as having the best democratic experience because of their constitutional stability. As a matter of fact, the phenomenon of frequent constitutional amendments in emerging democracies is viewed by many scholars, not only as an indicator of dangerous political instability, but also as a sign of absence of democratic consolidation (Fall, 2008, 2009, 2011; Loada, Fall, Badet, 2008; Badet, 2009; Kanté, 1996; C.G.D, 2008). Burkina Faso is in the middle when looking at the number of times its constitution has been amended in comparison with other West African countries, six times, since 1991. Senegal is another extreme, because of the frequency (every seven months on average) with which its 
constitution has been amended since 2001, according to the Open Society in West Africa. These three countries, due to their previously mentioned specificities, represent the various degrees to which constitutional amendments are being considered and dealt with in Francophone West Africa.

\section{The way forward}

In the remainder of my work, I outline a broader understanding of how constitutional amendment usually happens in a regular context, which allows me to make a clear distinction between regular constitutional amendments and the not so regular type of amendments, the non-consolidating constitutional amendments that my study is about. In chapter 2, I begin with a comprehensive overview of the literature on constitutional amendments focusing on the four ways constitutional amendment usually happens. This chapter allows me to examine the most important questions raised in the literature on constitutions such as: what is the best constitutional design? Should constitutional amendments be made rigid or flexible? How rigid? How flexible? Why should constitutions be amended? These major queries in the literature on constitutional matters help me set the stage to introduce constitutionalism in West Africa in a way that makes it easier to notice the strange nature of what I call non-consolidating amendments in Francophone Africa. Non-consolidating amendments are changes to constitutions that are often done with no popular consent. They involve a roll back of provisions considered fundamental democratic principles (C.G.D, 2008). Chapter 3 offers a precise definition of these amendments and provides some clues on how to identify them. In chapter 3, after defining the concept of non-consolidating amendments, I enumerate all non-consolidating 
amendments made in each of the countries in my case study. I then apply my definition to each amendment to show why the amendment is not consolidating democracy or the rule of law. I conclude the chapter by suggesting that non-consolidating amendments could be avoided in the Francophone West African if certain conditions are met.

One of these conditions is addressed in chapter 4. In this two-section chapter I argue that an open constitutional amendment is more likely to produce a comprehensive and more consensual constitutional document. Such a thorough and consensual document is less likely to be revised for political purposes, my assumption being that it will be protected and defended by the parties involved based on the consensual context in which it was created (see chapter 4). The first section of this chapter examines the diversity of the participants in the drafting of the constitutional document, and the second one is concerned with the availability of information during the constitutional adoption period. The point is that the entire process leading to the adoption of a constitution matters for the quality of the final document that is produced. In other words, the openness of the constitutional adoption process has a great explanatory power when it comes to understanding the occurrence of non-consolidating constitutional amendments in Francophone West Africa; however, the constitutional adoption process is not the only factor that can be used to explain the entire phenomenon of non-consolidation amendments. One also needs to look deeply inside constitutional documents to see whether or not these documents themselves contain provisions that make them easier to abuse. As a matter of fact, most modern constitutions contain procedures for their own amendment. I argue that the design of these mechanisms of amendment can help 
understand how easy or hard it is for a constitutional amendment to be made. This is precisely the issue that my next chapter addresses.

In other words, the question in chapter 5 is whether there are provisions in the initial constitutional documents that make it easier to modify them. I examine the safeguards that each country's framers have engineered to address leaders' egoistic tendency to commit what Ouedraogo (2011) calls "constitutional frauds," i.e., nonconsolidating constitutional amendments. Actually, three points will be addressed here: the rigidity of the constitutional amendment process, the referendum as an amendment feature, and the public right to petition. As one can see, this chapter suggests that making constitutions harder to amend is a good idea in the particular West African context. Common sense, though, might suggest that constitutions should not be too hard to revise, as constitutions are made for people, and people have different needs from generation to generation. Moreover, in the context of Francophone Africa with a civil law tradition where judges are not as activist as their peers in the common law system, fundamental changes to the law might only happen through constitutional amendments, instead of through the judiciary. Why make constitutions hard to amend then? Chapter 5 responds to this particular question.

In chapter 6, I discuss the independence of the Judiciary, and particularly, the independence of the constitutional courts of the three countries included in my study, the argument being that an independent constitutional court would prevent illegitimate changes to the constitution. To assess the independence of the courts, I comparatively analyze in my case study countries: the appointment of judges to the court; their term in office, and the way they are removed from office. To measure the independence of the 
courts, I also take a look at litigations involving government officials and cases about elections to see how constitutional courts deal with them.

Chapter 7 is the concluding chapter in which I discuss all my findings. I comparatively discuss the three factors that I used to explain non-consolidating constitutional amendments (my independents variables): openness of the amendment process; mechanism of amendment; and the independence of the judiciary. I show how these variables individually affect the phenomenon of non-consolidating constitutional amendment. I conclude that the single most important factor in preventing nonconsolidating amendments is the openness of the constitutional adoption process. I suggest that my findings about the phenomenon of non-consolidating amendment can be generalized beyond my three study countries. They can be applied to any democratizing country with similar characteristics specified in chapter 3 . 


\section{Chapter II: Literature on the constitutional amendment process}

\section{Introduction}

Constitutional stability is commonly perceived as an indicator of the state of democracy in a given country. In other words, frequent constitutional amendments are viewed as suspicious in the sense that they raised some doubts about the commitment of a country to democratic principles (Lutz, 1994; Sturn, 1970). The conventional wisdom suggests that as the frequency of constitutional revisions increases, the likelihood of the executive branch of government getting more powers at the expense of civil rights increases (Roberts, 2009). ${ }^{9}$ Based on these assumptions, some scholars (Buchanan and Tullock, 1962; Riker, 1982) believe that new democracies should adopt rigid constitutions to secure freedom and rights for citizens against potential tyranny from the executive power or the majority. The point is that there are potential risks of tyranny whenever constitutions are being revised. The question then becomes why do countries not make unchangeable constitutions once and for all?

\section{Queries in the literature}

While safeguards could sometimes preserve constitutions against unnecessary alterations, amendments are still inevitable. Sometimes, they are even desirable:

We are not to expect perfection in this world; but mankind, in modern times, have apparently made some progress in the science of government. Should that which is now offered to the People of America, be found on

\footnotetext{
${ }^{9}$ The author only mentions the idea, but he does not support it. He argues in contrast with this idea, that in post-communist Europe, amendments tend to reduce the power of executives and provide for more human rights.
} 
experiment less perfect than it can be made, a Constitutional door is open for its amelioration. George Washington cited in Vile (1992, p.49)

According to Vile, the first president of the free United States of America and the Founding Fathers of the United States knew about Hebrew history from the Bible and classical Greek and Roman history, and they certainly learned from them while designing Article V of the US Constitution. Both sources, according to the author, demonstrate that unchangeable laws might have unintended consequences. Constitutions should not be too flexible neither should they be too rigid. This brings us to a major debate about constitutional amendments. What is the best constitutional design and how should constitutions be revised?

According to Lutz (1994), any people who are serious about constitutionalism will amend their constitution when needed instead of using unconventional or extra constitutional means. As the constitutional literature shows, many scholars believe that something is fundamentally wrong when constitutions are too often altered (Sturm 1970). A moderate amendment rate is a sign that the people living under a particular constitution are taking constitutionalism seriously (Lutz 1994). Actually, the amendment rate is the most important factor considered by many scholars (Loada, Fall \& Badet, 2008).

A successful constitutional system would seem to be defined by a constitution of considerable age that has a total number of amendments which, when divided by the constitution's age in years, represents a moderate amendment rate - one that is to be expected in the face of inevitable change. A less-than-successful constitutional system will have a high rate of constitutional replacement (Lutz 1994, p.367)

The question then becomes, what should be perceived as a moderate rate of amendments? Roberts (2009) and Lutz (1994) try to address the issue through some hypotheses. Even though both authors worked based on the same hypotheses (the former 
repeatedly citing the latter), they end up with different views on how important an amendment rate is for a constitution. While Lutz focus on amendment rate to determine the seriousness of a country's attachment to constitutionalism, Roberts (2009) is more concerned about the results of constitutional amendments. His study focuses on postcommunist Europe and concludes that amendments made to constitutions after the breakdown of the Soviet Union do not increase executive power. They rather help entrench human rights. Without clearly saying it, Roberts (2009) seems more concerned with amendments' results, instead of their rate. Other authors such as Holmes and Sunstein (1995) argue that it makes more sense to have a very flexible amendment process, suggesting then that the amendment rate should not raise any red flag when it comes to a country's commitment to constitutionalism. After all, a flexible constitutional amendment process helps a transitional country deal with the many changes (economic and political) that necessarily occur when a country moves from a non-democratic system to constitutional democracy.

One thing that scholars seem to agree on is that the longer a constitution is the higher its amendment rate will be. May (1987) and Lutz (1994) argue that one of the reasons state constitutions are frequently amended in contrast with the U.S. national Constitution is that they include more provisions with many details that make them targets for amendments. In other words, the shorter a constitution is, the lower its amendment rate will be. Reanalyzing Lutz's data, Ferejohn (1997) argues that, legislative procedures, not referenda, drive constitutional amendment rates higher. This idea is similar to the point made by Roberts (2009) when he argues that constitutions with elements that resemble ordinary legislation tend to be altered like ordinary legislation 
(frequently). Because long constitutions tend to possess such features (elements that resemble ordinary legislation), it is not surprising that they are usually more frequently amended than shorter ones.

Legislative procedures drive the constitutional amendment rate higher, and amendments done through legislative means usually require legislative supermajorities. In others words, for a government to use legislative procedures for amendments, it needs a supermajority in the parliament. In countries with weak opposition parties, it is easier for a government to obtain a supermajority in the parliament (Robert, 2006). A government with a supermajority in democratizing countries is likely to engage in frequent constitutional amendments (Loada, Fall, \& Badet, 2008). This idea confirms my assumption in chapter 3 that without a strong opposition party in the parliament, the ruling party is likely to have a free ride to politically motivated constitutional amendments. I show in my case study that besides Benin, where no government has yet been able to obtain a supermajority in the parliament, the ruling party constantly has a supermajority that ends up with more amendments to the constitutions.

Another assumption that seems to draw consensus among constitutional scholars is that more restrictive amendment rules lead to fewer amendments. However, as Lutz warns, this assumption has not been formally tested. According to him, the assumption may not be easy to test unless one is able to develop an index for measuring the degree of difficulty associated with an amendment process. Roberts (2009) acknowledges this idea, but he adds that one important factor that should not be left out is the manner in which a constitution is adopted, what I refer to in chapter 4 as the openness of the constitutional adoption process. The author cites Bunce and Csanadi (1993) who make the point about 
postcommunist Europe that constitutions adopted in haste are more vulnerable to amendments because of correctable flaws and also because of the failure to include all important actors in the drafting process.

Whatever differences might oppose scholars on constitutional amendment procedures, one main idea seems to unite them: constitutional amendments are indispensable. There are many reasons that make constitutional amendments necessary. The expansion of state functions, technology development, rapid urbanization or population growth, economic changes, the need for fair treatment of minority groups (for instance women's emancipation in West Africa) are among some of the factors that require a new legal environment. In some countries, namely countries with common law tradition, many of these changes can be dealt with using judicial interpretation. In the civil law tradition where the stare decisis doctrine is "not accepted," one cannot expect the judiciary to fill in for any lack of constitutional amendments, for the simple reason that in the civil law tradition, judges look more like "operators of a machine designed and built by legislators. The judicial function is a mechanical one" (Merryman \& PerezPerdomo, 2007, p.36). The point is that constitutional amendments are indispensable particularly in Francophone West Africa with the civil law tradition, where judicial activism seems more restricted. Consequently, for a viable constitutional democracy, there needs to be a fair and good constitutional amendment mechanism. We are then back to a major question in the constitutional amendment literature: What is the best constitutional design? The next section reviews the literature that addresses this question by examining different methods used for constitutional amendments. In this section, I also review the different features that can be used to make amendments more difficult 
with the objective of preserving constitutions against unwanted or non-consolidating amendments.

\section{The ways constitutional amendments happen}

Constitutional amendments and particularly the effects of amendments are an under-investigated area of research with few empirical works (Congleton \& Rasch, 2006). The authors cite Lutz's (1994) pioneering investigations on constitutional amendment procedures, constitutional length, and the amendment rate. In fact, a constitution's length, the difficulties of its amendment process, and the rate of amendment give us a sense of what principles could guide a constitutional design. $\mathrm{He}$ distinguishes four ways through which constitutional amendments happen: periodic replacement of the entire constitutional document; formal amendment process; legislative revision, and judicial interpretation. According to him, the last three prominent methods of constitutional modification reflect declining degrees of commitment to popular sovereignty. In other words, the level of commitment to popular sovereignty is a key factor for defining the nature of a political system. The modern written constitutions, first developed in America, were primarily grounded in the doctrine of popular sovereignty (Adams 1980; Morgan 1988).

American politicians used the language of popular sovereignty even before Locke's Second Treatise was published to stress the concept of consent that gives power and popular sovereignty to a constitution (Lutz 1980; 1988). Popular sovereignty, as colonial America perceived it, required that a constitution be written by a popular selected convention and ratified in a process that elicited popular consent, which can 
ideally be reached through a referendum. The point to be made is that early Americans understood the difference between a regular law-making process and constitutional matters which require a distinctive and highly deliberative process. Such a process is usually longer and more difficult than the one used for normal legislation. Because fallibility is part of human nature, colonial America believed that more seriousness should be put into constitutional drafting even though there is still room for change once experience shows the need to do so.

In this line of reasoning, Sturm (1970) distinguishes between major and minor constitutional alterations. He calls major modifications of constitutions "revisions" and minor ones "amendments." Actually, there is no consensus in the literature about the use of these terminologies. Lutz (1994) uses "amendment" to refer to the formal process of constitutional modification, and he uses "alteration" to describe a process that uses the legislature or the judiciary. It is important to distinguish between formal constitutional amendments and those used as "window dressing" (Lutz 1994), because as mentioned above, the method chosen for a constitutional revision always reflects the degree of commitment to popular sovereignty. An amendment made through the legislature (particularly when a parliament is dominated by one party) with no involvement of the population through a referendum carries less legitimacy than one done through a full participation of the people.

Although there seems to be a consensus in the literature about the necessity to distinguish constitutional matters from ordinary legislation (Lutz 1994; Lijphart 1999; Anckar and Karvonen 2002; Lorenz 2005), the question that remains unsolved is whether constitutional amendments should be made rigid or flexible, how rigid and how flexible? 
Several authors suggest different techniques. For instance, Hylland (1994) cited in (Congleton \& Rasch, 2006) proposes four techniques: Delays, confirmation by a second decision, qualified majorities, and participation of actors other than the National Assembly. Lane (1996, p.114) suggests six mechanisms: referendum, confirmation by a second decision, delay, qualified majorities, confirmation by subnational government, and no change. Lijphart (1999, p. 219) lists four methods of amendments: ordinary majorities, between two-thirds and ordinary majorities, two-thirds majorities or equivalents and supermajorities greater than two-thirds. Elster (2000, p.101) suggests: adoption by a majority in parliament, absolute entrenchment, requirement of a higher quorum than for ordinary legislation, delays, state ratification, and ratification through referendum. Lutz (1994) presents four general amendment strategies: legislative supremacy, intervening election (double vote), legislative complexity (referendum threat) and required referendum. I have chosen to pay closer attention to the strategies suggested by Lutz because his pioneering empirical investigation work in this field of constitutional amendment has been acknowledged by many scholars, including Congleton \& Rasch (2006): Ferejohn (1997); Roberts (2006), Giovannoni, (2003).

After focusing on American states and national constitutions, Lutz (1994) uses 32 national constitutions to point out the particular specificities attached to each of the four amendment strategies he proposes. The feature used in the legislative supremacy strategy is to make one legislative vote sufficient to amend the constitution. According to the author, it does not matter what the size of the required majority is for the vote; this strategy when used, most of the time, leads to higher amendments rate to the constitution. Moreover, legislative supremacy strategy reflects a minimal commitment to popular 
sovereignty. It also reflects a minimal commitment to deliberative process. That is to say this strategy does not privilege consensus as much as other strategies such as the legislative complexity or the referendum strategy do. Since one legislative vote is sufficient to amend the constitution, a government may only need to have enough seats in the parliament to introduce any kind of amendment that is likely to be adopted by the National Assembly, due to the simplicity of the mechanism. Non-consolidating amendments may easily pass through this type of strategy that is not radically different from a procedure used to pass ordinary laws.

The intervening election or double vote technique requires that the national legislature adopt an amendment by votes in two sessions with an intervening election. In other words, the first legislature that votes on the amendment may not be the exact same legislature to vote for the second time on the same amendment. Here there is a notion of delay made necessary because of the second vote, something that gives more chances to the legislature to have a second look at an amendment before it is formally adopted. In this procedure, there is a clear distinction made between constitutional matters and ordinary or normal legislation through the double vote and an intervening election. Another advantage of this strategy is that with the intervening election, citizens are given a chance to influence the process by using their votes to put into office those whom they trust to take care of a proposed amendment. According to Lutz, the introduction of difficulties into the amendment process in this strategy translates in a lower amendment rate.

Legislative complexity adopted by countries such as France, Italy, Spain, and Sweden is usually characterized by the use of multiple paths for the amendment process. 
A particular characteristic of this strategy is the use of a referendum threat. A president can use this feature to bypass the legislature and obtain a referendum on a given issue. Usually a referendum can be called by the executive, or by a relatively small number of parliament members (this number varies depending on the country considered). A referendum can also be called on the initiative from a small percentage of the electorate. Because of the complexity of the referendum and how it can be called, this strategy is viewed as more deliberative. Moreover, the strategy as presented also emphasizes the difference between a normal legislature process and constitutional matters, which shows the degree of importance given to the constitution as the fundamental law in the land. Legislative complexity produces a lower constitutional amendment rate compared to the other two strategies presented above (Lutz 1994).

The author argues that his last and fourth suggested strategy, called the referendum strategy introduces the most direct form of popular sovereignty. It not only emphasizes more strongly the deliberative process of constitution adoption, but it also sets a clear distinction between constitutional matters and ordinary legislation. Countries that adopt this strategy (Australia, Denmark, Japan, Switzerland, Venezuela, Ireland, and the U.S.) require referendum as the final step of the amendment adoption process.

A quick summary of constitutional literature shows how scholars have been struggling to theorize a viable constitutional design, from Buchanan and Tulloch (1965) to Lutz (1994). Different authors use different terminology to address the same question. For instance, Weingast (2004, 2005), Robinson (2004) and Fearon (2000) refer to the issue of the best constitutional design using the concept of self-enforcing democracy. Gibbons and Rutten (1996) prefer to talk about self-enforcing constitutions. The question 
though is how this western literature applies to the particular African context that I am concerned with. In other words, how does the constitutional literature I just reviewed help me study the constitutionalism of developing West African countries that seems to take place in a different context? Based on culture and also the developing stage of the countries studied, it is worth mentioning the difference of context between constitutionalism in the West and that in West Africa; however, as van de Walle (2009) suggests, differences should not be used as an excuse to avoid comparisons. Seen in a certain way, constitutionalism matters in West Africa may not be as different from constitutionalism in the West as it seems. First of all, Francophone African constitutions are notorious for their similarities with France's 1958 Constitution (Assistance, 1998). My case study countries, like France, practice legislative complexity, as a constitutional amendment strategy.

When theorizing about new democracies, scholars are often concerned about democratic consolidation (Diamon 1999, p.66). Linz \& Stephen (1996, p.5) argue that consolidation only occurs when democracy is the "only game in town." I argue that there is a gap in the constitutional literature regarding the phenomenon of non-consolidating constitutional amendments. Essentially, non-consolidating constitutional behavior is a particular characteristic of constitutionalism in West Africa that needs to be examined.

\section{The West African context}

Constitutions that brought most West African countries into statehood (in the 1960s) generally established multiparty systems modeled after their respective former colonizers (Abutudu 2009). Post-colonial Sub-Saharan African governments had 
constitutions that provided for the separation of powers, an independent judiciary, and the protection of human rights. However, constitutional practices in the newly independent countries did not last long. They succumbed to military takeover and single party systems (Akiba 2004), two post-colonial phenomena created by political practices in Sub-Saharan Africa. In many countries, military coups and counter-coups have become the mode of political succession in power. When the military gets into power, the very first action is usually the suspension of the constitution; consequently the separation of powers or the independence of the judiciary have little or no real meaning.

According to Akiba (2004), the widespread adoption of single party rule was the most important phenomenon that ended up killing constitutionalism and the rule of law in Africa. The single party system is characterized by the official or unofficial proscription of all opposition parties. Power is concentrated in the hands of the ruling party. Proponents of the single party system argued in the 1960s that the Western constitutional model of government with its multiparty system was bound to fail in Africa because "Western constitutionalism represented a foreign idea that had no place in African history, tradition and practice; that individual rights and the separation of powers were incomprehensible to the African masses," according to President Julius Nyerere cited in (Akiba, 2004). ${ }^{10}$ This view, which was widely accepted by early African elites, helped develop a form of governance that heavily relied on presidential supremacy. The view

\footnotetext{
${ }^{10}$ The quotation belongs to President Julius Nyerere of Tanzania and can be found in: Ujamaa - the Basis of African Socialism: 1977, Oxford University Press. This view has been discredited in wider intellectual circles. Contemporary wisdom in many African countries suggests that individual rights and the separation of powers should be subject to generally accepted rules and not to arbitrary government decisions Ojwang (1990), Ekeh (2004) strongly disagrees with the idea that constitutionalism is incompatible with Africa values. He shows that in most pre-colonial African countries the sovereignty belonged to the people. Things only changed with the impact of Europeans imperialism and the Arab influence in Sub-Sahara Africa.
} 
was based on the assumption that weak new African countries needed strong leaders. The executive was then set, from the beginning of most African states, to be the dominant branch of the government with a very limited check of power (Prempeh, 2010). Another argument used by proponents of this system was based on the assumption that rapid economic growth in Africa requires some form of authoritarian control.

This argument not only reinforced the postcolonial African nationalistic view suggesting that a strong nation needs a strong government, but it also has had some support from the former colonizer, namely France, which cared much more about stability than democracy in West Africa. While national conferences were taken place in Africa, Jacques Chirac, then Prime Minister still insisted that multiparty system might not be right for Africa (Clark, 1997. p 2). A similar idea is developed by Akiba (2004) about the International Monetary Fund and the World Bank, institutions that he believes are often too quick to scarify civil and political rights in the pursuit of economic development. Authors such as Akindele (2003) points out that economic liberalization was the main agenda of the Breton Woods agencies even though at the end, their push for good governance and political accountability through what is known as "conditionality" helped deliver more transparency and democracy. The problem today is not any more whether West African countries have entered the era of democratization. The pressing issue is rather how to consolidate the new democratic institutions in countries where a new phenomenon has emerged: the non-consolidating constitutional amendment phenomenon that consists in African presidents using their often overwhelming majority in the parliament to modify constitutions for personal interests.

This poses a stability issue in these developing countries where the practice of 
personal rule largely trumps the practice of the rule of law as it exists in consolidated democracies such as the US.

When I say politics ... it is not a question of the art of governing the State for the public welfare in the general framework of the laws and regulations. It is a question of politician politics; the struggles of clans not even ideological tendencies - to place well oneself, one's relatives, and one's clients in the cursus honorum, that is the race for preferments (Jackson and Rosberg 1984, p .421)

This quotation from former Senegalese President Léopold Sedar Senghor effectively summarizes what is meant by personal rule or the paradigm of the big-man.

According to Jackson and Rosberg (1984), there is no indication that the political behavior of personal rule is about to decline in Africa any time soon. Others share opposite views (Posner and Young, 2007; Sklar, Onwudiwe \& Kew, 2006). These authors suggest that the formal rules of the political game in Africa are beginning to matter in a way they previously have not. They reject the long held assumptions among political science scholars that Africa is a continent where formal institutional rules are largely irrelevant. To make their point, Sklar, Onwudiwe \& Kew (2006) use the case of former Nigerian president Obasanjo, whose party attempted in vain to amend the Nigerian Constitution in order to maintain him in power.

Actually, formal institutional rules matter, since leaders even when they intend to go against democratic ideals (for example when they choose to overstay their mandate in power) usually feel the need to go by the rules in order to amend the constitution in ways that make it favorable to them (Posner and Young, 2007). Empirical data collected by these authors from 46 sub-Saharan countries and including 227 leaders on how leaders exit power show that from the 1990s to the year 2005 the trend has changed and more African leaders leave power following natural death, voluntary resignation, or losing an 
election instead of through a coup d'état or through assassination. This optimistic assessment about the practice of the rule of law in Africa, however, may not reflect reality of the state of democracy in Francophone West Africa. As a matter of fact, by using legal means to modify constitutions for personal interest African politicians necessarily weakens the rule of law and creates the same kind of unhealthy political environment that characterized the era of personal rule (before the 1990s).

According to Owona (1985), the use of democratically unhealthy maneuvers to circumvent constitutions that are supposed to entail the free will of a sovereign people is a practice he calls (in French) constitutionalisme rédhibitoire, which refers to nonconsolidating constitutionalism. Maltz (2007) suggests that presidential term limits be clearly stated in any African constitution to make the costs of modifying this particular provision domestically and internationally very high for any president who dares to touch it. For him, presidential term limits are now being perceived as a key feature of democratic governments and should be watched and protected against malicious and dangerous interference by selfish and egoistic politicians. The truth is that African leaders use their countries' constitutions for their personal interest because they do not have any deep commitment to constitutional and democratic values imported from the former colonizers (Okoth-Ogendo, 1996).

According to this author, the failure of constitutionalism in Africa is due to what he called four fallacies. Africa's colonizers assumed that colonialism was a preparatory phase in the evolution of constitutional government. The British and the French thought their mission in Africa was to "civilize" indigenous Africans by introducing basic arts of government so that when it came time to take over, Africans would be able to replicate 
what they had learned. Many African scholars share this view, however, what needs to be emphasized is that the art of governing that was taught to indigenous people had nothing to do with true democracy or true constitutionalism (Converse et al., 1992).

What the British and the French were doing in London and Paris in terms of democratic practices was qualitatively different from what they were teaching in Abidjan, Ouagadougou, Cotonou, or Dakar. "Nowhere in Africa could the system of government under colonialism be classified as constitutional or democratic in the Westminster or Montesquieulian sense" (Okoth-Ogendo, 1996, p.50). Actually, colonialism was an autocratic, despotic, and repressive government. Consequently, when African leaders took over, they continued exactly the autocratic form of government that the colonizers had taught them. To be fair, it makes sense to acknowledge that the colonizers are not necessarily responsible for the authoritarian behavior of the founding fathers or leaders of African countries. Of course, colonization was not democratic and the practices that the colonial administration taught to the would-be African founding fathers were all, but democratic. However, as Loada and Ibriga (2007) argue, the African leaders' authoritarian behavior has some roots in pre-colonial African culture which considered power as sacred since leaders obtained their power from divinity. Such a conception of power creates the tendency toward authoritarian behavior from leaders who cannot stand any criticism.

Moreover, because of colonial history, constitutions were viewed as a colonial heritage that ignored African specificities and this is the main reason for the failure of constitutionalism in Africa (Kanté, 1996). Leaders perceived constitutions as instruments for the conservation of political power. To suggest that western liberal democracy is 
incompatible with African values, however, is an argument that many African leaders do not support, because such reasoning undervalues African culture (Conac, 1993).

For Abutudu (2009), constitutionalism in Africa after independence faced two major issues: the military takeover and the slide toward single party rule. The new wave of democratization and constitutionalism that started in 1980 also faces a serious challenge: the prominence of the presidential type of regime in many African countries. This particular type of regime, where the executive branch holds too much power, has almost reduced the legislative branch to an appendage of the executive. Consequently, the oversight function of the legislature is not taken seriously since the parliament members seem to be there only to approve whatever the executive suggests (Fayemi, 2001). Abutudu proposes a debate on ethics and power in politics in order for Africa to enjoy a real culture of constitutionalism, the type of constitutionalism that includes the principles of the rule of law in the sense of Lon Fuller's "internal morality of law" (Fuller, 1969).

\section{Conclusion}

As one can see, African constitutionalism has been addressed in various ways. Some authors have studied the adaptability problems of imported constitutions (Kanté, 1996; Hesseling, 1996; Okoth-Ogendo, 1996). Other authors studied constitutional politics and elections in Africa (Hyden, 2006; Lindberg 2009; Maltz, 2007; Posner and Young, 2007; Van de Walle, 2009). There is still a gap in the literature when it comes to the new phenomenon of non-consolidating constitutional amendments that my dissertation addresses. The phenomenon consists of incumbent political leaders to engineering targeted constitutional changes in their favor with the ultimate goal of staying in power .i.e., they undo constitutions to overstay their mandate or to protect 
particular interests. This practice less known for outside observers creates an uneven political playing field that usually guarantees reelections for incumbents, because incumbent power holders often have disproportional access to state resources, media, and legal system, that they abuse (Levitsky \& Way, 2010). "The advantages of incumbency in Africa are so great that elections - even free and fair elections - are not enough to put meaningful limits on presidential power” (Posner \& Young, 2007, p. 65). Greene (2007) addresses the same issue of incumbent advantages in terms of a single-party dominance. The author shows that dominant parties often turn public resources into patronage goods. This practice allows them to bias elections in their favor. As a matter of fact, it allows them to "virtually win elections before election day without resorting to electoral fraud or bone-crushing repression" (Greene, 2007). Although $81 \%$ of Africans desire free and fair elections that would remove incumbents (Diamond, 2010, p. 53), incumbent presidents lost only fourteen times out of a hundred reelection bids in 46 Sub-Saharan African countries between 1990 and 2005 (Posner \& Young, 2007). 


\section{Chapter III: Non-consolidating constitutional amendments Introduction}

In the 1990s, a democratic reawakening in Africa was informed by the adoption of new constitutions to mark a rupture with the past series of military coups d'état that the continent had previously experienced. After over twenty years of democratic governance, however, certain states particularly in Francophone West Africa have started rolling back some of the basic democratic principles included in their initial constitutions. This phenomenon has created an unfriendly environment for the rule of law. Constitutions that were adopted through referendums are being modified through National Assemblies.

Clearly, there is nothing wrong with amending a constitution from time to time in order to adapt it to the evolving needs of the people (Fall, 2011; Garané, 1997; Vile, 1992). The problem has to do with the ways constitutional amendments are being done and the nature of the amendments themselves. Changes to a constitution that are done without consensus and that involve a rollback of provisions considered fundamental democratic principles are necessarily suspicious and probably troublesome. Amendments done under such conditions are the ones I call non-consolidating amendments.

In this chapter, I first define the term non-consolidating constitutional amendment. Next, I enumerate all constitutional amendments made in each of my case study countries. I then apply my definition to each amendment and decide whether it is consolidating or non-consolidating of democracy. I conclude that there has been no politically motivated constitutional amendment in Benin since the adoption of its Constitution in 1990. Burkina Faso has experienced three non-consolidating amendments 
out of a total of six amendments since 1991. Of fifteen amendments done in Senegal from 2001 to 2012, ten are non-consolidating constitutional amendments.

One needs to keep in mind that my case study countries are newly democratized nations. To be fair or more realistic, let's say that they are democratizing countries as these former authoritarian countries are making their first steps into constitutional democracy. In other words, I am studying countries with a young and fragile democratic culture. It is in this context of young democratic experience that the concept of nonconsolidating constitutional amendment is used to refer to particular types of changes to constitutions that do not advance democratic principles. I argue that a constitutional amendment can either advance democracy or slow the process of democratization down. Those amendments that help advance democracy and the rule of law are referred to as consolidating, others are deemed non-consolidating.

"An important issue in the conceptual debate on consolidation is: How do we recognize it? Certainly no single indicator will do. And it is easier to recognize the phenomenon in its absence: the signs of fragility, instability, and non-consolidation" (Diamond L., Plattner, Chu, \& Tien, 1997, p. xxi). According to Linz \& Stepan (1997, p. 15), consolidated democracy refers to "a political regime in which democracy as a complex system of institutions, rules, and patterned incentives and disincentives has become, in a phrase, 'the only game in town.' Consolidation requires self-binding procedures of governance that can only be altered by exceptional majorities.

However, a democracy in which a single leader enjoys or thinks he or she enjoys 'democratic' legitimacy that allows him or her to ignore, dismiss or alter other institutions - the legislature, the courts, the constitutional limits of power - does not fit our conception of rule of law in a democratic regime. (Linz \& Stepan, 1997, p. 19). 
This particular argument is consistent with my suggestion that the amendment of Article 37 of Burkina Faso's constitution is a non-consolidating amendment as it dismisses the constitutional presidential term limit of a particular leader in the middle of the democratic game. Constitutional democracy is about binding rules that should not be changed while the game is in process.

The consolidation of constitutional democracy is not just about free and fair elections. Free and fair elections can take place with no democratic consolidation because of the uneven democratic playing field and the non-consolidating political behavior of leaders (Levitsky \& Way, 2010; Sartori, 1976; Diamond 1999). This is why many authors challenge Huntington's double turnover theory of democratic consolidation (C.G.D, 2008). For Beetham (1994), when talking about democratic consolidation it is necessary to go beyond procedural definitions of democracy based on fair, honest, and periodic elections to more normative ideas. The point that the author makes is that even with free and fair elections a long-lived democracy may not be consolidated because of a lack of sincerity in the democratic game (this is what I refer to in my work as non-consolidating behavior). Free, fair, inclusive, and competitive elections constitute basic principles of democracy: however, political and social freedoms (not only during elections, but also between elections) need to be taken into account when deciding about the fairness of competitive elections (O'Donnell, 1994, p. 41). According to the author, many analysts skip this important indicator of electoral fairness because they do not see elections as institutions, and more importantly they only focus on legality. Actually, nonconsolidating behavior is not only about politicians breaking formal rules, it is also about informal rules. 
For example, Przeworski argues that democratic consolidation occurs 'when no one can imagine acting outside the democratic institutions.' But this does not preclude the possibility that the games played 'inside' the democratic institutions are different from the ones dictated by their formal rules. (O'Donnell, 1994, p. 47)

For example, it is not because a president has the required majority to modify a constitution to stay in power that doing so means consolidating democracy. By doing so, a president does not violate democratic rules; however, he or she does violate the spirit of the rules by changing the rules while the game is still ongoing. This is what I refer to as a non-consolidating constitutional amendment. Bratton (2010) addresses the phenomenon using the term informal institution. Clientelism (the expression of political loyalty to providers of patronage) is an informal institution. Although a constitution might limit the presidential term in office, a president through clientelism can easily secure an amendment and claim that he or she did nothing wrong since the formal rules were followed to get the constitution modified. The thing that usually goes unnoticed by outside observers is the informal rule or clientelism that allows a president to secure support even for unpopular political behavior. In African presidential regimes,

Regardless of constitutional arrangement ... power is intensely personalized around the figure of the president ... He is literally above the law, controls in many cases a large proportion of state finance without accountability.... (van de Walle, 2003, p. 310).

Democracy refers to regimes that hold elections in which the opposition has some chance of winning and taking office (Przeworski, Alvarez, Cheibub, \& Limongi, 1997). Democratic consolidation, however, goes beyond pure legality. It requires that robust democratic culture be part of people's daily lives. This means that even through a difficult crisis political leaders with strong support from the public will still adhere to democratic procedures (Dahl, 1997). As the literature review shows, scholars suggested 
many definitions of democratic consolidation. They, however, seem to agree that there is more to the concept of consolidation than just elections, whether fair or not (Dahl, 1997; O’Donnell 1994; Przeworski, Alvarez, Cheibub, \& Limongi, 1997; van de Walle, 2003; Braton, 2010; Beetham, 1994; Lewitsky \& Way, 2010).

Constitutional democracy is a system of government in which the power of government is defined and limited based on the fundamental law (a constitution) adopted by the people. Constitutional democracy requires the principles of checks and balances and the separation of powers (Akiba, 2004). The notion of the rule of law embodied in constitutional democracy requires that all citizens, including government officials, be subjected equally to the same rules and laws (Marryman \& Perez-Perdomo, 2007). To put this broad concept of constitutional democracy in the African context, let's say that the basic principle of constitutional democracy is about the predictability of a state's action. Capriciousness or unpredictability is the mark of tyranny or dictatorship (Zoethout, Pietermaat-Kros, \& Akkermans, 1996). The main goal of constitutionalism is to set up fundamental rules that assure predictability of a government's action. When constitutions are frequently modified, the predictability of a government's action is jeopardized, and the return to tyranny is imminent. This is why constitutional amendment raises concerns in democratizing countries, particularly in those where there is a tendency to reverse course on major issues that are viewed as signs of progress toward consolidation of democracy (Fall, 2011). Presidential term limit is one example among others (CGD, 2008). To deal with this issue Article 23 ( $5^{\text {th }}$ clause $)$ of the African Charter for Democracy, Elections, and Governance clearly states that any constitutional amendment 
that jeopardizes the principle of alternation in power is unconstitutional and should be punished by the African Union.

According to Stéphane Bolle, cited in Fall (2011), in democratizing countries that experience authoritarian regimes, a constitutional amendment is always dangerous when it touches issues such as presidential term limits (the length or the number of mandates); eligibility to the highest office of the country (the issue of nationality); immunity for former presidents against judicial action; and the creation of a Senate to assure domination of the party in power. The amendment of presidential term limits is dangerous for the consolidation of democracy mainly because it raises legitimate questions about the opportunity for change. "The advantages of incumbents in Africa are so great that elections - even free and fair elections - are not enough to put meaningful limits on presidential power" (Posner \& Young, 2007, p. 131)”. In countries where incumbents always win every single election even when international observers attest to the fairness of elections, a desperate opposition that believes it has no chance of ever getting to power is poised to used illegal means such as coups-d'état to achieve change. Although $81 \%$ of Africans desire free and fair elections that would remove incumbents (Diamond, 2010, p. 53), incumbent presidents lost only fourteen times out of a hundred reelection bids in 46 Sub-Saharan African countries between 1990 and 2005 (Posner \& Young, 2007). To address this issue, African drafters of the 1990s constitutions created presidential term limits. By the end of 2005, thirty-three African constitutions contained provisions on presidential term limits (Prempeh, 2010).

Due to African leaders' obsessions with presidency for life, drafters of new constitutions tried to curb presidents' powers by making it mandatory for them to leave 
office at a certain period defined by the constitution. By forcing incumbent power holders to leave office at a certain point, opposition leaders have some gleam of hope for accessing the highest electoral office. More importantly, by providing hope for the opposition, presidential term limits also provide hope for the survival of democracy in former authoritarian countries where democratic rules have not always been the means for getting into power. Due to the history of presidential power abuses I just described, one can understand why alternation through presidential term limit is considered a key provision in the 1990s African constitutions. I am not however, suggesting that changeover of power automatically produces democracy, nor do I suggest that alternation is synonymous with democratic consolidation. Instead, I argue that alternation or changeover of power is one fundamental aspect in the process of democratic consolidation, particularly in countries where presidents are known for abusing their term in office.

The issue of nationality is a dangerous one for reasons similar to those involving presidential term limits. Questionable laws of nationality are often used to prevent serious contenders from taking part in elections. In the introduction to my work, I have already mentioned the case of current Ivorian president Alassane Dramane Ouattara who was prevented from taking part in the 2000 presidential election after Article 35 of the Ivorian Constitution was passed. War broke out in the country that culminated in the then sitting president Gbagbo being brought before the International Criminal Court (ICC) where he is still awaiting trial. The creation of a Senate follows the same logic of conservation of power by incumbents. Incumbent power holders usually turn to the creation of Senates when they do not have the required majority to amend the constitution to allow the 
president to stay in power. This is the case in Burkina Faso where the president is set to leave office in 2015 and needs to amend the constitution to stay. The real problematic issue with the creation of Senates is that presidents get to nominate a considerable numbers of Senators who then become their clients and help them pass favorable laws through congresses ${ }^{11}$

This survey of non-consolidating amendments is not complete as there are other types of amendments that are difficult to classify. Actually, they can best be described as amendments for revenge. Here is an example: Karim Wade, the son of former Senegalese President Abdoulaye Wade, was given the task of organizing the Islamic summit to be held in 2008 in the capital city of Senegal. After the event, Macky Sall, the President of the National Assembly, asked Karim Wade to present an accounting of the money spent for the summit. President Wade was enraged that the parliament would dare to ask his son to appear before the National Assembly (Scales-Trent, 2011, p. 92), so he used a constitutional amendment to remove the President of the National Assembly. Article 62 of the initial Senegalese constitution of 2001 stated that the President of the National Assembly is elected for the full length of the legislature (5 years). The constitutional law 2008-67 of October 21, 2008 was introduced to modify the first clause of Article 62. The amendment consisted in taking that particular clause out of the constitution into the internal rules of the Assembly. The internal rules of the National Assembly state that the president of the National Assembly is elected for one year only. One of the reasons for moving the provision of Article 62 into the internal rules of the Assembly is that the National Assembly's rules deal with the kind of internal parliamentarian business that

\footnotetext{
${ }^{11}$ More details on issues considered dangerous for democracy or its consolidation are given in the analysis of each amendment below.
} 
attracts less attention from the media than the constitutional amendment process. These internal rules are easier to manipulate. Moreover, the National Assembly internal rules include a provision that allows its members to vote their president out if needed. At the time, President Wade's party held a comfortable majority at the National Assembly (131 out of 150 seats). Macky Sall was ousted. This is the particular context in which I am defining the concept of non-consolidating constitutional amendments.

\section{Definition}

Non-consolidating constitutional amendments are amendments that are not intended to reinforce democracy or the rule of law. Instead, non-consolidating amendments are designed to reinforce the political power of an individual or a group of individuals through targeted constitutional changes engineered to manipulate electoral and other political laws in favor of incumbent power-holders. To determine whether an amendment in question is non-consolidating or not, I consider five indicators: the general context of governance in a given country; the specific context in which an amendment is made; the motivations for the amendment; the consolidating principle that the amendment can be tested against; and the non-consolidation aspect of the amendment. This is shown in table 4 that serves as a sample table for my non-consolidation test to identify amendments.

Table 4: identifying a non-consolidating constitutional amendment

\section{The Amendment}

General characteristic of countries with non-consolidating amendments

* Uneven playing field: incumbent power holders control the state resources, the media, and the legal system (Levitsky \& Way, 2010). 
Executive hegemony with a dominante political party (Diamond \& Plattner, 2010; Fall, 2008).

* Incumbent party holds the majority of seats in the parliament (C.G.D, 2008).

\section{Specific context of the amendment}

\begin{tabular}{|l|l|l|}
$\begin{array}{l}\text { Motivation for the } \\
\text { amendment } \\
\text { (the rationale for a } \\
\text { constitutional amendment) }\end{array}$ & $\begin{array}{l}\text { Principle in Violation } \\
\text { (the principle that is } \\
\text { being violated when a } \\
\text { non-consolidating } \\
\text { amendment is made) }\end{array}$ & $\begin{array}{l}\text { Non-consolidating aspect } \\
\text { (the particular aspect that } \\
\text { makes an amendment } \\
\text { questionable or unfit in } \\
\text { term of constitutional } \\
\text { democracy) }\end{array}$ \\
\hline
\end{tabular}

General context of governance: Because non-consolidating constitutional amendments are prevalent in countries with certain characteristics of governance, the first step in identifying a non-consolidating amendment is to look at the state (the health) of democracy in a given country. This is important because a similar amendment that is considered non-consolidating in a democratizing country may not be considered so if done in a consolidated democratic country. For example, if the US were to amend its $22^{\text {nd }}$ amendment to remove the presidential term limit, such an amendment would not a priori be a non-consolidating amendment for many reasons. Democracy in the US does not present the symptoms of non-consolidation such as instability, fragility, clientelism, absence of commitment to constitutionalism.

For an amendment to be classified as non-consolidating, it must be designed to benefit an individual political actor or group holding power at the time of the amendment adoption. Amendments that satisfy this criterion usually fail to fit common sense democratic practices known in well-established democracies. ${ }^{12}$ Non-consolidation is

\footnotetext{
12 What I refer to as common sense democratic practices include principles such as the respect for constitutionally established institutions and the principle of checks and balances, as well as the commitment of politicians to defend and respect their country's constitution-all things that constitute the core values of constitutional democracy.
} 
recognizable at the declining commitment on the part of major actors to the rules of the constitutional democratic game (Diamond, 1999; Mattes \& Thiel, 1999). According to Gunther, Diamandouros, and Puhle (cited in O'Donnell, 1994), there are five indicators of democratic consolidation: alternation in power between former rivals; a continued strong support for democracy during times of extreme economic hardship; regime stability in the face of some radical structuring of party system; successful defeat of strategically placed rebels; the complete absence of antisystem party or social movement. Democracy in a given country cannot be defined as consolidated when the country experiences signs of instability or fragility or when leaders use informal rules such as clientelism in their daily practices of governance (O’Donnell, 2010; Linz \& Stepan, 2010; van de Walle, 2003).

One of the major symptoms of non-consolidation is what Levitsky \& Way (2010) call the uneven playing field. According to these authors, democratic competition is undermined less by electoral fraud or brutal repression of opposition than by unequal access to state institutions, the media, and state resources.

"We define an uneven playing field as one in which incumbent abuse of state generates such disparities in access to resources, media, or state institutions that opposition parties' ability to organize and compete for national office is seriously impaired. These disparities rarely emerge naturally; rather, they are usually rooted in illicit or autocratic behavior, including partisan appropriation of state resources, systematic packing of state institutions and state-run media and politicized distribution of state resources, concessions and licenses" (Levitsky \& Way, 2010, p. 58).

One might argue that incumbent advantages exist everywhere, even in advanced democracies where pork-barrel spending is a common practice. Yet, there is a big difference between a regular incumbent advantages and what Greene (2007) calls "hyperincumbent advantage.” 
In a developed country with many media outlets, incumbent control of stateowned media may not have the same dramatic and negative effects on democratic quality compared to a similar situation in a developing country like Burkina Faso where only state-owned radio can reach remote areas to spread government propaganda. In poor countries, incumbents can use state-owned $4 \mathrm{X} 4$ vehicles to access remote areas that remain inaccessible to impoverished opposition leaders. Moreover, incumbent power holders may use state policy to punish businesses that finance the opposition. In Ghana, entrepreneurs who supported opposition parties in 1992 were denied government contracts (Oquaye, 1998, cited in Livitsky \& Way, 2010). In many democratizing countries such as Burkina Faso and Senegal, incumbents control the judiciary ${ }^{13}$ and the electoral authorities. This ensures that major electoral and other legal disputes are resolved in favor of the ruling party. A skewed playing field is not always visible for outside observers of democracy who evaluate the fairness of elections based on a time frame that does not include the period between elections. Unfair competition between elections determines the results of futures elections. An outsider observer of elections in a democratizing country will certainly label as a violation of civil liberties a government's closing of an opposition-owned media or the arrest of an opposition leader, but he or she may not understand the multiple informal techniques used by incumbents to starved oppositions to submission. For example, Article 4 of the Burkina Faso opposition status law states that members of opposition parties are not allowed to occupy high level state offices. With an underdeveloped private sector, government jobs are important revenue sources in many developing countries. By preventing opposition members from

\footnotetext{
${ }^{13}$ See chapter V on Judicial independence.
} 
occupying prestigious offices, the ruling party is inciting ambitious leaders to switch parties in exchange for well-paid and prestigious jobs. Similar behavior from former Malian President Amadou Toumani Touré led the country to be almost without opposition as major opposition leaders joined the ruling party.

Another major sign of democratic non-consolidation is the presence in a country of a dominant executive power with one dominant political party that usually holds the majority of seats in the parliament. This particular indicator or sign often exists in cases of incomplete transition to democracy from single-party rule.

"Single-party regimes tend to fuse the state and ruling party, creating a highly politicized state in which bureaucrats are also party properties, and resources from state agencies are systematically deployed for partisan use. Transition to multiparty rule - often accomplished via a simple constitutional change or the calling of elections - do not necessarily alter these patterns ... and this helped incumbents to retain power in a multiparty context" (Levitsky \& Way 2010, p.64).

As a matter of fact, a skewed playing field is often a legacy of an incomplete transition to democracy such as in Burkina Faso where President Compaoré, a military leader who came to power through a coup d'état, successfully negotiated transition to democracy and multiparty system in which he and his new party $\mathrm{CDP}^{14}$ retain hegemonic party control over the country. This hegemonic one-party control secures a political environment in which an uneven political playing field is created and nurtured.

Poverty and underdevelopment facilitate the creation and maintenance of an uneven political playing field. In countries with an underdeveloped private sector, opposition parties cannot rely on the private sector to finance their election campaigns. In such conditions, the public sector takes on disproportionate importance because

\footnotetext{
${ }^{14}$ CDP Congrès pour la Démocratie et le Progrès (Congress for Democracy and Progress)
} 
government officials use public buildings, public employees, public vehicles, public media, and any other public resources for the campaign. This helps governments to coopt opposition leaders, activists, and even businessmen who are interested in getting government contracts. All these advantages make incumbency a too great advantage visà-vis the opposition in countries with extreme poverty. Using Mexico as a case study, Greene (2007) shows that many analysts fail to understand the importance of the disproportional resource advantages that incumbents enjoy. The point is that the general context of governance is an important indicator to consider when trying to identify a nonconsolidating constitutional amendment in a given country. Through my brief description of the terrain in which informal rules, corruption, and clientelism flourish, I made the point that non-consolidating amendments mainly occur in fragile, unstable countries with weak democratic culture and therefore a weak commitment to the rule of law or constitutionalism. The second indicator to look at for a sign of non-consolidating constitutional amendments is the specific context of the amendment.

Specific context of the amendment: The best way of using this indicator is to ask the following questions: When, why, where, and how is the amendment being made. As a reminder, non-consolidating amendments are designed to reinforce the political power of an individual or a group of individuals through targeted constitutional changes engineered to manipulate electoral and other political laws in favor of incumbent powerholders. Before asking the other questions one needs to know what is amended. By asking what provision in the constitution is amended, one gets to understand the importance of a given amendment. As mentioned above there are specific issues that are considered vital or essential for the survival and consolidation of democracy in unstable 
and fragile democracies. When constitutional provisions like presidential term limits, amnesty for political leaders, and the creation of a Senate are made, there is a great risk for political turmoil or retreat of democracy. By asking the question when a specific amendment is made one gets to focus on the circumstances and political environment surrounding the specific time frame of an amendment. The specific circumstances help understand the real motivations and practical implications of an amendment even when government officials suggest otherwise. Suppose a president's party just lost the majority in the National Assembly, the president is one year away from the end of his mandate, and he has already suggested that he had no intention in leaving office. The president then introduces a draft of a constitutional amendment that would create a Senate in which he would have the right to nominate more than a third of the Senators. The point that I am making here is that the specific context matters in understanding the real motivations for the amendment. ${ }^{15}$ Knowing why a particular amendment was made allows one to focus on the real and hidden reasons for the amendment. When asking the question why this amendment, one implies why this amendment instead of a different one. This leads to a consideration of all possible reasons that might determine whether the amendment really helps democratic consolidation process or not. Knowing where the draft of the amendment comes from is a valuable information. It helps one get a clear idea about the real implications of an amendment, because politicians are strategic actors and usually act in their own interest (Lida, 1998). If the amendment comes from the legislative branch, it matters to know who the author is. It also matters to know whether the initiator is from the opposition or the ruling party. According to Fall (2011), the executive branch often

\footnotetext{
${ }^{15}$ The specific case of the Burkina Faso constitutional amendment to which I am referring will be addressed at length later on when I discuss each individual amendment.
} 
uses individual MPs to draft unpopular amendments to which they do not wish to attach their name. By asking how the amendment is made, I can discover whether there was a consensus during the adoption of a particular amendment at the National Assembly. In other words, I can know whether the ruling party passed the amendment alone or with some opposition members. This is important in contexts where there are different types of opposition parties, some being called radicals and others, moderates.

Motivation for the amendment: It is important to know the official reasons that led to the suggestion or adoption of a particular amendment. Once the motivations for the amendment and the amendment itself as a new constitutional provision are known, one can objectively evaluate the practical implications of such a constitutional change and decide whether it promotes democracy or an individual interest. The motivation for an amendment is known in Francophone West African National Assemblies as l'exposé des motifs (the rationale for the amendment). It usually consists of a written statement that lays out the rationale for the law to be voted on. L'exposé des motifs is an official document. When reading such a document, a reader needs to objectively evaluate the practical implications of the amendment instead of relying on the reasons given by government officials as the real motivations behind an amendment are not always clearly presented (Fall, 2011, p.98). My task is to compare the official rationale for an amendment to the real and practical implications of the amendment in the light of democratic principles I cited above, such as the commitment to constitutionalism (Akiba, 2004; O’Donnell, 2010; Linz \& Stepan, 2010; Van de Walle, 2003), the need for changeover of power (Huntington, 1991), the respect for formal rules (Prosner \& Young 2007; Braton, 2010) and the commitment to free and fair elections (Przeworski, Alvarez, 
Cheibub, \& Limongi, 1997) instead of the politics of an uneven playing field (Levitsky \& Way, 2010; Sartori, 1976; Diamond 1999; Greene 2007). Here is an illustration of what I mean by objectively evaluating the practical implications of an amendment.

Article 37 of Burkina Faso's initial Constitution states that the president of the country is elected for seven years and he can be reelected once. The constitutional law 002/97/AN of January 27, 1997, was introduced to change this provision. The new Article 37 now states that the president is elected for seven years and that he can be reelected. Only one word (once) was taken out of the old version of Article 37. However, the omission of this single word dramatically changed the meaning of the provision. The objective implication of the new provision is that there is no limits on the president of Burkina Faso seeking reelection. While one can argue that a president is elected by the people who may give him or refuse him their votes, I suggest in my literature review above, using Greene (2007) and Levitsky \& Way (2010), that the great advantages for incumbents in poor and fragile democratic countries together with the informal practices of an uneven political playing field make the reelection of African incumbents almost always certain. Previously indeed, incumbent presidents lost only fourteen times out of a hundred reelection bids in 46 Sub-Saharan African countries between 1990 and 2005 (Posner \& Young, 2007). This is why changes to a constitution that give an open-ended option for reelection of a president is problematic in countries with a long history of authoritarian regimes. President Compaoré came to power through a coup d'état in 1987, and he has been in office since then. Moreover, the initial intent of the constitutional framers was to limit the presidential term in office. This particular provision was included in the constitution with the precise formulation based on a minimal consensus between 
the opposition and the ruling party (C.G.D, 2008). More importantly, by amending the constitution in the middle of the democratic game to allow President Compaoré to stay in power, the ruling party showed no commitment to constitutionalism. Constitutional democracy is about predictability of a state's action. When rules are being modified in the middle of a game, there is obviously a problem of fairness (Zoethout, PietermaatKros, \& Akkermans, 1996). The danger with this amendment is that it might give an incentive to the opposition to use unconventional means to seize power once convinced that democracy does not offer any real path for ever getting into power.

According to President Compaoré's party, the new provision restores fairness and obeys democratic principles that require freedom for citizens to elect whoever they want as Head of State. The new change was then introduced to allow citizens to enjoy their civic and political rights laid out in Article I of the Burkina Faso's Constitution. Article I states "discriminations of any sort, notably those based on race, ethnicity, region, color, sex, tribe, cast, political opinion, financial situation and birth, are prohibited" (Loada, Fall, \& Badet, 2008, p. 20). For the initiators of the amendment, the original Article 37 that limited presidential terms to two was discriminatory against President Compaoré who is a Burkinabe citizen like anyone else. Although the official reason for this amendment does not say that the new provision gives President Compaoré a green light for an unlimited presidency, it is obvious in the light of the explanations given above that the new version of Article 37 does give the president precisely that opportunity. This way of interpreting and understanding the new Article 37 is what I refer to as objectively evaluating the real implications of an amendment. 
Some critics might suggest that there is nothing wrong in modifying the constitution to let a president stay in power as long as the amendment is done legally. Actually, non-consolidating constitutional amendments are not necessarily illegal. What I am suggesting is that they are illegitimate because they are against basic principles of constitutionalism, such as the commitment to the rules of the democratic game (Loada, 2003). I argue that the amendment of Article 37 serves the interest of a single individual. The original Article 37 was voted through a referendum and later modified through legislative means. In democratic constitutionalism, a referendum carries more legitimacy than a vote made by single-party members (International IDEA, 1998, p. 68).

Open-ended questions in the Round 3 AfroBarometer survey suggest that Africans usually define democracy in terms that value alternation of power ("majority rule" or "change in government") instead of using language such as "power sharing" or "working together" (LeVan, 2011, p. 38).

This can be explained by the lack of confidence in African governments due to the overwhelming domination of the executive branch in these presidential and semipresidential regimes.

In those countries with a highly centralized and hegemonic executive branch, ${ }^{16}$ the ruling party usually holds the majority of seats in the parliament. In such conditions, the National Assembly becomes a proxy or a pulpit for the executive branch instead of being an institution with the ultimate mission of controlling government's action (Fall, 2008; Prempeh, 2010). When the executive and the National Assembly are led by the same party, politicians behave as if they were in a one-party regime type in which the parliament exists just to approve drafts of laws sent by the executive (Thomas \&

\footnotetext{
${ }^{16}$ See Scales-Trent (2011) for a better understanding of the overly powerful executive branch in Senegal. The same issue is addressed as autocratic personal rule by Diamond (2010).
} 
Sissokho, 2005). "Conscience voting and open display of independence by a majorityparty legislator are frowned on and harshly punished...such undemocratic and oligarchic party control over legislators invariably inures to the benefit of presidential power" (Prempeh, 2010, pp. 26-27). As a matter of fact this is how the situation looks in Burkina Faso and Senegal where there have been several constitutional amendments.

According to Fall (2012), the electoral system used in Senegal allows the emergence of supermajorities. For legislative elections, Senegal uses a party-list ballot system wherein candidates are first chosen by their national party's committee. There are no political party primaries as in the US. Candidates are chosen by their party then put on the party's list ballot. Voters go to the polls to vote for the party and not necessarily for a particular candidate, because there are no individual lists of candidates. Candidates are introduced in the race by their party. Consequently, Members of Parliament (MP) have to obey ${ }^{17}$ their party whose leader is the president of the country. They rarely vote against an executive constitutional amendment draft for fear of losing their seat. They may not be on the party's list for the next legislative elections if they challenge the president in the parliament. The president, as the party leader, gets to choose who is allowed on the party's list for elections. This practice is seen as favoring irresponsibility on the part of elected officials since MPs are not individually responsible before their constituencies

\footnotetext{
${ }^{17}$ Constitutional democracy provides for two different types of mandates for Members of Parliament (MPs): an imperative mandate that is the result of the popular sovereignty theory and a representative mandate that comes from the national sovereignty theory. MPs with an imperative mandate are delegates with a mandate from their electoral constituencies. This type of mandate does not allow a MP to vote according to his or her personal judgment. He or she must vote according to the preferences of the constituency. With a representative mandate, an MP is not required to vote according to his or her constituency because the MP represents the nation and not a particular constituency. This type of mandate, used in all three of my study countries, has the disadvantage of making MPs unresponsive to their immediate constituencies. Consequently, MPs are more responsive to their party than to their constituencies, which adds to the power of the president who can easily control Members of Parliament through party discipline.
} 
(Good, 2003). The worst fallout from the list ballot system is that it guarantees party discipline and more importantly, it guarantees MPs' loyalty to the president. "Contrary to conventional wisdom, cohesive and highly disciplined political parties do not always strengthen the legislature" (Barkan, 2010, p. 45). Highly disciplined political parties may be very useful and desirable in parliamentarian regimes. This is not necessarily the case in presidential or semi-presidential regimes, because a prime minister who abuses power is more likely than a president to be checked through a vote of no confidence by the opposition or even a loss of support from his fellow party members. Early elections are one option often used to deal with crises in parliamentarianism. These options are not available in presidential regimes or semi-presidential ones (Linz \& Stepan, 1997, p. 20) such as in Burkina Faso or in Senegal where the president is not even responsible before the National Assembly. While a Prime Minister can be removed by a vote of no confidence, a president can only legally be removed by the process of impeachment because he or she is elected for a constitutional prescribed period. While a Prime Minister's decision-making process is guided by the principle of collegiality with other ministers, the president has only advisers and subordinates whose advice he or she can freely ignore when deciding (Lijphart, 1999, p. 118). In case of serious crisis, presidents often fire their prime ministers or the entire government, but rarely leave office. These practices make the executive a hegemonic branch of the government with a president who gets to enjoy a very limited check on his governance (Prempeh, 2010; Fall, 2009; CGD, 2008). 
Unlike Benin, which uses proportional representation with the largest remainderHare formula, ${ }^{18}$ Senegal has a mixed legislative electoral system that uses proportional representation and plurality. Although the use of plurality can be justified by the fact that a government needs some kind of majority to govern, the formula of plurality used in Senegal is one of the least proportional electoral systems Katz (1997) cited in (Creevey, Ngomo, \& Vengroff, 2005). In the 2001 legislative elections, ${ }^{19}$ with only $59.6 \%$ of the votes, the party in power (PDS) won 89 of the 120 seats at the National Assembly. The party that came second in the race (PS) only got 10 seats with $17.2 \%$ of the votes. This is the type of electoral system that Linz \& Stepan (1997, p. 19) suggest is not likely to be conducive to democratic consolidation. The Senegalese parliament is similar to the Burkinabe parliament that also uses the same practice of the list ballot system. The difference is that in Burkina Faso the electoral formula is the proportional representation with the highest average-Hare formula. ${ }^{20}$ This particular formula is considered the least proportional of all proportional representation formulas. It allows an over-representation of the ruling party (Santiso \& Loada, 2003). The point that I am making is that the electoral system chosen in Senegal and Burkina Faso contributes to making the executive

\footnotetext{
${ }^{18}$ The proportional representation with the largest remainder-Hare formula that is used in Benin is favorable to small parties (Zarka, 1996, p. 27). This method consists of allocating the rest of seats to the largest remainders of unused suffrages. This means that even parties that were not able to have the electoral quotient might still get a seat at the National Assembly. As a reminder, the electoral quotient is calculated by dividing the total suffrages of an electoral circumscription by the number of seats available for that particular circumscription (Loada \& Ibriga, Droit constitutionel et institutions politiques, 2007, p. 266). This electoral system was used in the 1991 Beninese legislative election. With this system is it hard for a single party or a coalition of parties to obtain the required majority in the Beninese National Assembly in order to amend the constitution (Loada, Fall, \& Badet, 2008).

${ }^{19}$ In the 2001 legislative elections, 65 seats were allocated based on a plurality system and 55 on proportional representation.

${ }^{20}$ This formula was used before the changes to the electoral code adopted in July 2001. The changes consisted in replacing the highest average-Hare formula by the largest remainder-Hare formula. Two types of electoral districts were introduced. 90 members of parliament are now elected from 13 regional districts instead of 45 districts, and 21 members of parliament are elected on a national list (Santiso \& Loada, 2003).
} 
a too powerful branch that can freely manipulate the constitution for political purposes. Moreover, unlike in the English-speaking African countries, in many countries of the Francophone world electoral codes are not included in the constitution. Consequently, they are manipulated at will by politicians to stay in power. The electoral code in Burkina Faso has been modified seven times from 1991 to 2002 (Loada \& Ibriga, 2007, p. 265). Changes in the electoral code to win elections became such a prominent practice that the ECOWAS ${ }^{21}$ protocol of 2001 on Democracy and Good Governance forbids partner countries from making any significant political changes six months before any national election.

Principle in violation: After evaluating an amendment through the analysis of the general context of governance in the country where the amendment is made, and after studying the specific context in which the amendment was done, and after analyzing the motivation for the amendment, the time has come to review the democratic principles that a non-consolidating amendment would violate with its passage through the legislature. These principles have already been mentioned above in the literature review and also in the section where I examine the motivations for an amendment. They are: the commitment to constitutionalism and respect for the principle of the balance of power, the commitment to free and fair elections, and the respect for formal rules instead of the practices of clientelism and the politics of the skewed political playing field. All these basic democratic principles require respect for civil rights and due process of law, including checks on executive power and the independence of the press. For example, a journalist has been jailed in Côte-d'Ivoire for suggesting that President Bédié's presence

\footnotetext{
${ }^{21}$ ECOWA (Economic Community of West African States)
} 
at a soccer game had brought bad luck to the Ivorian team, a clear case of the lack of freedom of the press. It also shows that the executive controlled the judiciary, and more importantly it shows how overly powerful executive power can be. The point is that consolidation of democracy involves the widespread internalization of democratic culture that would provide support and acceptance of democratic procedures (Dahl, 1997). As a matter of fact, consolidation requires more than the so-called double turnover test promoted by Samuel Huntington. Karl (1996) warns against the specter of a "fallacy of electoralism" that consists of measuring democratic consolidation based on the single criterion of elections. While you cannot have democracy without elections, you can indeed have elections without democracy (Bratton, 1999). The point is that free and fair elections can coexist with systematic abuses of the political rights of the opposition and all other types of non-consolidating political behaviors from the ruling party. For example, incumbents who are intent on retaining their office can engineer electoral rules that would keep serious contenders out of the electoral race. For example, they can either use an age requirement or create a "nationality clause" in the constitution or the electoral code designed to exclude potential opponents (Monga, 1999, p. 51). This was the case for former president Kenneth Kaunda in Zambia and Alassane Ouattara in Côte-d'Ivoire (Gyimah-Boadi, 1999, p. 37). Incumbents can also purposely alter the timing of elections to increase their chances of holding power. If elections that are supposed to be held in two years are suddenly due in one year, this can be a major handicap for an opposition party that lacks crucial financial means and may not be ready on time for competition. All these non-consolidating political practices are prominent in what Zakaria (1997) calls illiberal democracy. 
The Non-consolidating aspect: this refers to the element in the constitutional amendment that makes it a non-consolidating amendment. The determination of the nonconsolidating aspect of a law is the final step in the process of identification of a nonconsolidating constitutional amendment. One can only get to this step after a meticulous analysis of the general context of governance in a given country, the specific context of an amendment that is being examined, the motivation or reasons for the amendment in question, and the democratic principle that is considered to have been violated or disregarded. It is only after this process that one can reasonably and convincingly argue about the non-consolidation or the anti-democratic nature of a constitutional amendment. Non-consolidation is multiform. Broadly defined, non-consolidation includes all the informal rules or techniques engineered by politicians to circumvent formal democratic rules for political gain. This includes any sophisticated political behavior aimed at creating and maintaining an uneven playing field, corruption, clientelism, abuses of state resources by incumbents, the monopoly of public media for propaganda in favor of incumbents, and the use of the law to favor the incumbent's political agenda. The latter aspect of democratic non-consolidation is the focus of my work: the use of the constitution to advance the individual interest of a politician or the interest of the ruling party. This is what I call non-consolidating constitutional amendments. When reading a constitutional amendment, one needs to look for signs of the different non-consolidating aspects I mentioned above using democratic consolidation literature. After describing the process used to detect and identify non-consolidating constitutional amendments, time has come to put my formula to the test. 
The process is as follow: I first describe the amendment in question, then I proceed to individually evaluate the non-consolidating indicators described above. To avoid repeating myself while examining each individual amendment, I will no longer be describing the general context of governance as the context described above applies to all the amendments I discuss below. In other words, the democratic non-consolidating indicators that I will be evaluating in each individual amendment are: the specific context of the amendment, the motivation for the amendment, the consolidating principle that applies to specific amendment, and the non-consolidating aspect that makes me conclude that a particular amendment is a non-consolidating one. There is a summary table that introduces each individual amendment. In other words, the written text below each amendment summary table is the detailed description of all the indicators mentioned above for respective amendments. As a reminder, there are three non-consolidating constitutional amendments for Burkina Faso ten for Senegal and none for Benin.

\section{Evaluation of non-consolidating amendments}

Among my three study countries, Benin is the only country that has not experienced any constitutional amendment. Although there has been no amendment to the Beninese 1990 Constitution, there have been some unsuccessful attempts that need to be exposed. By looking at the failed attempts of amendment in Benin one can have a better understanding of how other countries with the same political environment could avoid unnecessary and dangerous constitutional amendments that often lead to political instability.

The stability of the Beninese Constitution is not due to the sole factor of constitutional rigidity. One needs to look at the conditions of adoption and the popular 
legitimacy of the constitution for clarification. The fact that the Beninese people are willing to fight to protect the constitution has to do with the perceived legitimacy of the fundamental law (Badet, 2009). According to the author, the proof for this claim was given two years before the end of President Kérékou's second term when a small group of Kérékou supporters started a debate about amending the constitution to remove its age limit provision ${ }^{22}$ and the presidential term limit. ${ }^{23}$ In July 2003, a civil society organization called Elan started a vast campaign known as “Touche pas à ma Constitution" (Hands off my Constitution). The campaign consisted in using big posters in Benin's major cities with messages against constitutional amendment. This had a snow ball effect. Media got interested in the issue and a national debate was started. For the movement Hands off my Constitution, a constitutional amendment about the provisions cited above, would necessarily damage the foundation of the consensus reached through the 1990 national conference that would result in a roll back of hard-won democratic principles (Adjovi, 2006). Faced with silence from President Kérékou on his intentions for a third term, thirty-three associations and civil society organizations joined Elan to put pressure on the president. In July 2005, President Kérékou announced that he had no intention in seeking a third term.

I would have considered an amendment allowing President Kérékou to stay in office to be a non-consolidating amendment for similar reasons I invoked earlier to make the case against the amendment of Article 37 in Burkina Faso. Benin as a newly democratized country, fits the prototype of countries whose general context of

\footnotetext{
${ }^{22}$ Article 44 of the Beninese Constitution requires that presidential candidates be between 40 and 70 year old.

${ }^{23}$ Article 42 of the constitution states that in no circumstances a president should serve more than two terms.
} 
governance I described as fragile, unstable with a weak democratic culture. Table number 1 shows the long period in which the country was under an authoritarian regime. It only emerged from that dark period in 1991 and was at its second turnover of power when the attempted amendment happened. In 2005, Benin was still struggling with all the nonconsolidating political diseases such as uneven playing field, corruption, and clientelism (Wantchekon, 2003; Adjovi, 2006). There is a specific context that qualifies this attempted amendment for non-consolidation of democracy. President Kérékou had been in power before from 1972 to 1991 . He had only left power after a sovereign conference forced him out. He returned to power after defeating Nicephore Soglo in 1996. More importantly, President Kérékou was at his last mandate when his supporters suggested an amendment to the constitution to remove the only two provisions (Articles 42 and 44) that could prevent him from running for another term in office. The practical implications of any amendment to remove these two articles would necessarily be the possibility for President Kérékou to run for office again. The non-consolidating aspect for such an attempted of amendment is the lack of commitment to the democratic game as stated in the 1991 Beninese Constitution. The democratic consolidating principle against which such a non-consolidating aspect is tested is obviously the commitment to constitutional democracy. Failing to respect that basic democratic principle necessarily leads to nonconsolidation of democracy. In this particular case, the amendment did not occur because President Kérékou under pressure from the Beninese people, announced in July 2005, that he had no plan to run for office.

The second attempt of constitutional amendment was proposed by two groups of individuals supporting President Kérékou. They suggested that because of the high cost 
of elections it would be a good idea to have presidential, legislative and communal elections held altogether on the same day. This would save money for the nation. The Finance Minister also supported the idea arguing that the state had no money, but when the United Nations Program for Development and the European Union offered their financial support, Kérékou's government declined it. Since the government was citing the lack of financial means to hold elections as planned in the constitution, a nongovernmental organization offered to lend money to the government (Dossa, 2005). The government rejected the offer. Civil society organizations started a voluntary citizens' fund for the Autonomous National Election Commission (CENA). It consisted in asking ordinary citizens to contribute financially to the organization of national elections. Seven millions CFA (around \$14000.00) were collected and given to the electoral commission. Moreover, ordinary citizens offered their own trucks to the electoral commission for the distribution of electoral material, and others offered computers. When all these initiatives were rejected, it became clear to the Beninese people that the government was trying to do away from its constitutional obligations to organize elections separately and in a timely fashion (Adjovi, 2006, p. 193). On June 23, 2006 the National Assembly went ahead and successfully passed an amendment ( 71 votes out of 83 members) to allow themselves to overstay their mandate by one year. The proposed amendment consisted in modifying Article 80 of the constitution so that MPs could stay in office for five years instead of four. By law DCC 06-74 of July 8, 2006 the Beninese Constitutional Court voided the amendment in these terms:

Given the fact that the four year tenure which is a constitutionally established fact is the result of a national consensus arrived at by the Conference of the bone and sinew of the nation in February 1990 and dedicated by the Constitution in its preamble stating again the fundamental opposition of the Benin people ... to 
power confiscation ; that even if the Constitution made provisions for the modalities of its own amendment, the determination of the Beninese people to create a State of law and pluralistic democracy, the safeguard of the legal security and the national cohesion impose that all amendments take into account the ideals that led to the adoption of the December 11, 1990 Constitution, especially the national consensus, a principle of constitutional value. Consequently, articles 1 and 2 of the constitutional law $n^{\circ} 2006-13$ adopted by the National Assembly on June 23, 2006, not respecting the principle of constitutional value, are contrary to the Constitution, and that there is no need to render a decision on other means. (Loada, Fall, \& Badet, 2008, p. 15).

In my description of the reasons that the first amendment attempted in Benin would have been a non-consolidating had it occurred, I cited literature to make the point that the general context of governance in Benin makes it eligible for the occurrence of non-consolidating constitutional amendments. In other word, the governance context in Benin fits my first criterion for the occurrence of non-consolidating amendments. I therefore proceed to examine my second indicator of non-consolidation: the specific context of the amendment. The particular context in this case is that the National Assembly members were at the end of their mandate in 2005. President Kérékou had a year left before the end of his second term. Suggestions were made to have all three elections (presidential, legislatives and local) held the same day in 2008. The practical implication of these suggestions was that President Kérékou and the National Assembly member would overstay their constitutional mandates. President Kérékou was supposed to leave office in 2006 and the National Assembly members had a mandate that expired in 2005. As the Constitutional Court's decision shows, the parliamentarians' mandate is four years long. Postponing elections even for one year supposed changing the constitution to allow more time for MPs in office, a move that required changing the rules while the democratic game was in progress. 
The motivation for the amendment is that having three elections altogether would save money for the country, which makes sense. The problem is that constitutional democracy comes with commitments. For the democratic game to work smoothly, all actors need to commit themselves to pre-established rules of the game (Dahl, 1997). Regularity of elections is part of these pre-established rules (Bratton, 1999). Predictability is a sign of stability and confidence, while capriciousness or unpredictability is the mark of tyranny or dictatorship (Zoethout, Pietermaat-Kros, \& Akkermans, 1996). The consolidating principle in this case is the commitment to the rule of democratic game. Overstaying a mandate is a non-consolidating political behavior. The initiators of the second attempt amendment in Benin cited financial issues as a reason for postponing elections. Yet, when the government was offered financial support, it repeatedly rejected the offer. Such behavior becomes suspicious, because among the multiple informal techniques used by incumbents to stay in power, there is one known as the practices of alteration of elections timing (Bratton, 1999). Opposition parties are often financially vulnerable to changes of elections timing. When elections are shortened, opposition may not gather enough resources in time to compete fairly. When multiple elections are held together the same day, opposition parties might have concerns about losing big if they are not ready or if elections are not transparent. By having multiple elections at different dates it minimize losses, since one might lose today and have a chance to catch up tomorrow in the next elections. By voiding the amendment, the Beninese Constitutional Court sent a message that the Court has no intention of setting a precedent for politically motivated constitutional amendments. Moreover, the Beninese 
people are fond of their constitution and they become nervous about any suggestion of constitutional amendment (Badet, 2009).

Table 5: Overstaying a presidential mandate

Amendment 002/97/ADP of January 1997

Specific context of the amendment

- President Compaoré came to power through military coup d'état since 1987

- President Compaoré was set to leave power at the end of his second term in 2005

\begin{tabular}{|c|l|l|}
\hline $\begin{array}{l}\text { Motivation for the } \\
\text { amendment }\end{array}$ & Principle in violation & Non-consolidating aspect \\
\hline \multicolumn{1}{|c|}{$\begin{array}{l}\text { Initial Article 37 } \\
\text { discriminates against }\end{array}$} & $\begin{array}{l}\text { Commitment to } \\
\text { constitutionalism }\end{array}$ & Unlimited term in office \\
$\begin{array}{l}\text { President Compaoré } \\
\text { Freedom of citizens to } \\
\text { elect whom they want }\end{array}$ & & \\
\hline
\end{tabular}

In Burkina Faso, there have been six constitutional amendments since the adoption of the constitution in June 1991. I consider three of them to be nonconsolidating amendments. The first one is the amendment 002/97/ADP of January 1997. This is the amendment of Article 37 regarding the presidential term limit I mentioned earlier. The amendment allowed members of parliament to remove some spelling errors in the constitutional document (Article $13 \& 59$ ). Some expressions with revolutionary connotations were also removed from the constitution. The part of the 1997 amendment that got more attention from media and that was seen as the real reason for the amendment was related to the presidential term limit (C. G.D, 2008, p. 16). The amendment made the presidential mandate an open-ended one by changing Article 37 of the Constitution to make it read that the president of Burkina Faso is elected for five years and that he can be reelected. "Although it was in conformity with Article 164 
paragraph 3 of the Constitution, [the 1997 amendment] affects an element, which is capital for our young democracy: the principle of political change made obligatory by the Constitutional Law of 1991" emphasis added (Loada, 2010, p. 53). According to Garané (1997), another change in the constitution that makes the 97 amendment undesirable is that it requires that proposals of amendments coming from the National Assembly be submitted to the government for opinion. This, according to the author contradicts the spirit of Article 163 of the initial constitution. One of the missions of the parliament is to act as a check on governmental power. That is why the parliament is given the prerogative to decide on both drafts and proposals of amendments. Having the last word on drafts and proposals of amendments is a restricted domain of competence for the National Assembly. It is not to be shared with the executive for the good reason that doing so undermines the constitutional principle of balance of power. By allowing the executive to give its opinion and eventually decide whether a proposal of amendment should be allowed, the 1997 amendment increases the power of the executive branch that can now influence amendments or laws from the National Assembly.

Since I have already discussed this particular amendment of Burkina Faso Article 37 above in the section where I explained how to identify a non-consolidating amendment, I will only briefly summarize the reasons why the amendment qualifies as a non-consolidating one. The specific context of the amendment is as follows: President Compaoré came to power through a coup-d'état in 1987. Then, he was in office until 1991 when he led the country to the transition to democracy and won elections the same year. In 1997, Article 37 was amended to allow an open-ended presidency in Burkina Faso. The official reason for amending Article 37 was to correct so-called discrimination 
against President Compaoré. The discrimination in question is the presidential two term limits included in the initial Burkina Faso Constitution of 1991. Another motivation for the amendment raised by the ruling party stated that by limiting the presidential terms in office to two, the initial constitution might impose mediocre candidates for the highly important office of head of state in Burkina Faso. The suggestion here is that besides President Compaoré, Burkina Faso lacks qualified candidates for the presidency (Loada, 2003, p.151). Such a motivation does not seem to stand up to any serious examination. After all, President Compaoré is not eternal and, when he is gone, Burkina Faso will still exists, as it has been the case for other presidents before him (Maurice Yameogo, Sangoulé Lamizana, Seye Zerbo, Jean-Baptiste Ouédraogo, and Thomas Sankara). The non-consolidating aspect of this amendment is the unlimited presidency for one individual: President Compaoré. As a matter of fact, President Compaoré won all presidential elections and has now spent twenty-seven years in office. I already mentioned why the initial constitution adopted, like many other constitutions in Africa, carries a provision for presidential term limits: African incumbents rarely loose elections (Young \& Prosner, 2007; Loada, 2003). The consolidating principle that allows me to argue that this particular amendment is non-consolidating of democracy is the principle of commitment to constitutionalism. Democracy is a political game with predictable principles that require commitment from all actors. Changing the rules while the game is in progress is nothing, but cheating the system. ${ }^{24}$

\footnotetext{
${ }^{24}$ On October 30, 2014, the Burkina Faso National Assembly was convened to vote on a constitutional amendment of Article 37 that could have allowed President Compaoré to stay in power for fifteen more years. The drafted amendment stated that the President of Burkina Faso was elected for a five-year term and that he or she could be reelected twice. As stated this amendment would have qualified as a nonconsolidating constitutional amendment according to my study had it become a law. Non-consolidating constitutional amendments are amendments that are not intended to reinforce democracy or the rule of law. Instead, they are designed to reinforce the political power of an individual or a group of individuals through
} 
Table 6: Extension of MPs mandate

Amendment 023-2012/AN of May 18, 2012

Specific context of the amendment

- The legislature was dominated by the ruling party

- The mandate of the legislature was set to expire on June 3, 2012

\begin{tabular}{|c|l|l|}
\hline $\begin{array}{l}\text { Motivation for the } \\
\text { amendment }\end{array}$ & Principle in violation & Non-consolidating aspect \\
\hline $\begin{array}{l}\text { Upgrading of the } \\
\text { elections system }\end{array}$ & $\begin{array}{l}\text { Commitment to } \\
\text { Need to assure regular } \\
\text { functioning of } \\
\text { parliament }\end{array}$ & $\begin{array}{l}\text { Overstaying a } \\
\text { constitutional mandate }\end{array}$ \\
\hline
\end{tabular}

In its decision number 2012-008/CC, the Burkinabe Constitutional Council

voided the constitutional law number 001-2012/AN of March 22, 2012, that was

supposed to modify Article 81 of the constitution to allow the National Assembly

members to overstay their mandate by at least six months and until a new legislature was

sworn in. The fourth legislature was set to expire on June 3, 2012. The initiator of this

voided amendment (President Compaoré) argued as a motivation for the amendment that

because of the upgrading of the electoral system, the National Independent Electoral

Commission (CENI) needed more time to get ready for the elections. The amendment

was then introduced to keep the National Assembly in place to ensure continuity until the

targeted constitutional changes engineered to manipulate the democratic game in favor of incumbent power-holders. After 27 years in office, President Compaoré was being given another chance to stay in power. The proposed amendment angered the Burkinabe people and provoked a popular uprising that brought President Compaoré and his government down. This uprising comes as a confirmation of my claim about the danger of non-consolidating constitutional amendments to the survival of democracy in democratizing countries. As a reminder, the initial Article 37 of the 1991 Burkinabe Constitution stated that the president was elected for seven years and that he could be reelected once. Therefore, President Compaoré was set to leave office in 2005 after his second term. In January 1997, Article 37 was amended and the word "once" was taken off implying that the president could be reelected indefinitely. Due to these terms of the new Article 37 and the reading that the Constitutional Council of Burkina Faso made of it, President Compaoré was able to stay in office for two more terms. In October, 2014 President Compaoré was at his $27^{\text {th }}$ year in office when he was ousted. 
new legislature could take over. The Constitutional Council voided the amendment on the ground that it was addressing a specific issue although constitutional law should be made to address general issues, not specific ones. The amendment was then corrected and reintroduced with a general purpose as suggested by the Constitutional Council. The new law (023-2012/AN of May 18,2012) would allow MPs to overstay their mandate whenever the government and the absolute majority of the National Assembly decide it is necessary.

I argue that this amendment does not consolidate democracy in Burkina Faso. As mentioned earlier, the official motivation for an amendment does not always state the practical implications of the amendment. Allowing MPs to overstay their constitutional mandate in office for whatever reason violates a constitutional obligation. The 1991 Constitution states that the National Assembly members are elected for five years. By taking it on themselves the right to extend their mandate MPs violate the initial contract between themselves and the people who voted for the constitution. If the National Assembly decides to extend its mandate, the new law should not apply to the sitting MPs: otherwise, it could be interpreted as a violation of voters' trust. The issue here is not whether there can be legitimate conditions that call for the government to postpone elections, instead the pertinent issue is a precedent that is being set and that can be used to manipulate the timing of elections for political reasons ${ }^{25}$ (Bratton, 1999). In a country with a well-established democratic tradition, this amendment would not raise any eyebrows, but in a country with new democratic experience, the issue take on greater

\footnotetext{
${ }^{25}$ I explained earlier in discussing the second failed amendment in Benin how elections timing could be used in favor of incumbent power holders
} 
importance. When the Beninese National Assembly used similar reasoning to amend the constitution, the Constitutional Court voided it on the ground that it was not consensual. To put this amendment through the test, we take a look at the specific context of the amendment. The legislature was dominated by the ruling party and the mandate of the legislature elected on May 6, 2007, was set to expire on June 3, 2012. Appendixes 3 to 7 below present the number of seats held by political parties in the Burkinabe National Assembly from the first legislature in 1992 to the fifth in 2012. A quick reading of these appendixes lets us understand that the ruling party has always dominated the National Assembly. This specific context is important because the electoral system of list ballot in Burkina Faso allows the president to control individual MPs who are essentially yesvoters, not only because of the clientelist system (Bayart, 1989; Walle, 2003), but more importantly because voting against an executive draft of an amendment may cost an MP his seat (Prempeh, 2010). This is the case in many African countries. In 2001, the Zambian ruling party expelled 22 legislators for their opposition to President Chiluba's bid for a third term in office. In Malawi, the consequences of an MP voting against his party is grounds for forfeiture of his seat. Article 77 of the 1991 Sierra Leonean Constitution explicitly states that MPs who vote against their party necessarily lose their membership in the party. An MP may be aware that a particular amendment is not consolidating of democracy, but might still vote for it to save his or her seat in the parliament. The consolidating democratic principle that was violated in the case in question here is the same as the one mentioned earlier in the case of presidential term limits: lack of commitment to constitutionally agreed upon principles of the democratic game. The MPs changed the rules while the game was still in progress. Abiding by rules 
is a constitutional constraint and a democratic duty. Overstaying a constitutional mandate is not consolidating of democracy, particularly not in countries with fragile democratic experience. In countries like Burkina Faso where democratic culture is not yet strong, it is not a good idea to set such a precedent as overstaying an electoral mandate. Because in African countries with a long history of authoritarian or military regimes, citizens judge democratic progress based on regular elections and alternation in power (LeVan, 2011; Loada, 2003), for a public long lasting commitment to democracy, people need to see that power use in a democratic regime is qualitatively different from power use in an authoritarian regime. This is important to create and maintain confidence in democracy as the "only game in town" (Linz \& Stepan, 1997).

\section{Table 7: Packing the parliament}

Amendment 033-2012/AN of June 11, 2012

\section{Specific context of the amendment}

- The ruling party lost the absolute majority in the National Assembly

- The President is in his last term in office, but shows no intention of leaving office.

- The amendment to create a Senate comes after a similar institution was suppressed

\begin{tabular}{|c|l|l|}
\hline $\begin{array}{l}\text { Motivation for the } \\
\text { amendment }\end{array}$ & Principle in violation & Non-consolidating aspect \\
\hline $\begin{array}{c}\text { Consolidation of } \\
\text { democracy in Burkina }\end{array}$ & $\begin{array}{l}\text { Commitment to checks } \\
\text { and balances of power }\end{array}$ & Packing the parliament \\
$>$ Better quality of laws & \\
\hline
\end{tabular}

Amendment 033-2012/AN of June 11, 2012 was broad. The initial constitution had 173 articles. The June amendment modified fifty-six and created five new ones. Two articles qualify this amendment for non-consolidation of democracy: Article 78 that introduces the Senate as a new institution and Article 168.1 that offers a complete amnesty to all former presidents of Burkina Faso. The Senate ( 89 members) as the 2012 amendment suggests contains elected members and members appointed (31) by President 
Compaoré. The day the amendment was passed with 88 votes an opposition

parliamentarian group walked out of the National Assembly in protest against the amendment. According to Afro-barometer, ${ }^{26}$ only $23 \%$ of the Burkinabe people support the creation of a Senate. Another element that makes the amendment so unpopular is that even Senators who are not appointed by the president are indirectly elected. One needs to be a local elected official to be allowed to vote or to be a Senatorial candidate. Besides the unpopularity of the creation of the Senate, Article 168.1 of the amendment offers a complete amnesty to all former presidents of Burkina Faso. The rationale for this provision is, according to the initiator, to provide the peace and stability that are necessary for the development of the country. In other words, all human rights violation cases and corruption that happened in the past should be forgiven for the sake of peace and stability. The major problem here is that an amendment of such importance is being made through a parliament that is dominated by the party in power with 73 seats out of 111. The Burkina Faso opposition suggests that President Compaoré had this amendment made to guarantee a safe haven for himself in case he happened to be out of power. ${ }^{27}$ They think that an amnesty in this particular context is hardly anything but the legalization of impunity. The particular context they refer to is as follows: The amendment was passed through a National Assembly dominated by the ruling party; the 2012 legislative elections have changed the configuration of the legislature and the ruling party no longer has the supermajority it enjoyed earlier; President Compaoré is closed to

\footnotetext{
${ }^{26} \mathrm{Afro}$ barometer is an independent research project that measures public attitudes on economic, political, and social matters in sub-Saharan Africa. It was cited in a Burkina Faso online newspaper entitled Le faso.net (May 20, 2013) (http://www.lefaso.net/spip.php?article54272

${ }^{27}$ See declaration of the Burkinabe opposition leader of September 11, 2013. http://www.lefaso.net/spip.php?article55868
} 
the end of his last term in office and will necessarily need more seats in the parliament if he decides to amend the constitution to stay in power as he already did in 1997, and more importantly, President Compaoré has shown no intention of leaving office at the end of his current mandate. Added to this context is the fact that Burkina Faso had already experienced a House of Representatives earlier. The experience was not a good one since the institution was suppressed in 2002 on the grounds that it was inefficient and costly for the country. Critics wonder why Burkina Faso needs a Senate now and why create an institution of such importance using a National Assembly dominated by the ruling party. In the African context, Senates are often created to guarantee the executive control over parliaments. Senegal represents a good illustration of such abusive used of Senates (Fall, 2011).

The official reason for a Senate is that it would help consolidate democracy in Burkina Faso by providing a better representation for the people in public affairs. Due to its function of double checking (together with the National Assembly), the Senate would provide a better quality of laws produced by the parliament. The Senate, unlike the House of Representatives that was suppressed in 2002 , is fully as competent to deliberate and control the government's action as the National Assembly does. These official reasons seem to be compelling arguments. The issue is that the official motivations for the amendment do not mention the practical implications of the creation of the Senate. Out of the 89 Senators, the president will be nominating 31 . Due to the context of corruption and clientelism that seems to be part of the daily political behavior in countries with weak democratic culture, the president's choosing a third of the Senate members raises some concerns about the legitimacy of the institution created in a non-consensual political 
climate. Even if the loyalty of the 31 presidential nominees is not necessarily guaranteed, the general political context dominated by informal practices makes it very likely that the president's nominees would vote alongside the ruling party. Moreover, the remaining Senators to be elected are chosen among local officials. This makes the process unfair, since the ruling party holds the majority of municipalities and would consequently win almost all Senatorial seats. The consolidating principle that is in jeopardy in this case is the principle of balance of power. The practical implications of the executive packing the parliament is a lack of legislative control over the executive branch that is already known to have too much power in semi-presidential and presidential Francophone African regimes (Fall 2011; C.G.D, 2008).

Parliaments often give African executives wide leeway in the exercise of authority: "even the selection of the speaker of parliament, which is everywhere the common prerogative of legislators, is in many instances ceded to presidents in Africa, enabling them to interfere with the day-to-day business of the legislature" (Prempeh, 2010, p. 24). In my three study countries, there is no confirmation process for presidential nominees. Consequently, African presidents are free to use their nomination power to coopt influential legislators. President Chiluba in Zambia appointed nearly half of legislators to ministerial positions. Legislators in fragile democracies are often more concerned with winning executive appointment than playing their constitutional role of controlling government action (Barkan, 2010). Because African countries often depend on foreign aid rather than domestic taxes, the Finance Minister's office through which external donors provide financial support is often more powerful than the legislature that depends on the good graces of the executive for resources. Consequently, lawmakers 
"become even more vulnerable to the lure of executive patronage and capture" (Prempeh, 2010, p. 25). According to this author, as long as the president is willing to use public funds and other resources to care for his supporters, the party's support for the president is all but guaranteed. It is in such a context that the right of a president to nominate a third of his country's Senators looks suspicious and problematic. The non-consolidating element in this amendment is that the president is seeking to pack the parliament for his political ambitions. Supporters of a Senate as described argue that this practice of nominating Senators exists in other countries. ${ }^{28}$ The reality that is lost in such an argument is that countries do not have the same democratic experience. Burkina Faso does not have a democratic experience as strong as the Canadian one, for example. By suggesting in December 2013 that he intends to consult the people on a possible amendment of Article 37, the Burkinabe president is in a certain way confirming what the literature on the creation of African Senates suggests: Senates are often created to help incumbents hold on to power. As a matter of fact, President Compaoré can no longer legally stay in office after 2015 unless Article 37 is amended once again. The ruling party, however, no longer has the required majority to do so. By creating a Senate, the president can achieve his goal of modifying the constitution, since it is very unlikely that he will nominate Senators from the opposition who might vote against him.

\footnotetext{
${ }^{28}$ In a response to a journalist who wanted to know why in Burkina Faso the president is allowed to nominate a third of the Senators, former President of the Burkinabe National Assembly Mélégué Maurice Traoré said that this practice exists in Canada, a country with a strong democratic tradition (http://www.lefaso.net/spip.php?article54272) .
} 
Table 8: Revenge /Clientelist amendments

Amendments: 2003-15 of June 19, 2003; 2007-06 of February 12, 2007; 2008-31 of August 7, 2008; 2008-32 of August 7, 2008

Specific context of the amendment

- Lack of consensus - lack of legitimacy in the creation of institutions for a president's friends in exchange of political support (Hesseling, 2010; Fall, 2011)

- Dissolution of an institution to remove its president (Thiam, 2007, p. 150)

- Creation and dissolution of Senates as revenge on the part of President Wade (Fall, 2011).

\begin{tabular}{|c|c|c|}
\hline $\begin{array}{l}\text { Motivation for the } \\
\text { amendment }\end{array}$ & Principle in violation & Non-consolidating aspect \\
\hline $\begin{array}{l}\text { Facilitate a social } \\
\text { dialogue (CRAES) } \\
>\text { For a better } \\
\text { representation of the } \\
\text { country (Senate) }\end{array}$ & $\begin{array}{l}\text { Checks and balances of } \\
\text { power }\end{array}$ & $\begin{array}{l}\text { Clientelism (CRAES, } \\
\text { CES) } \\
\text { Packing the parliament } \\
\text { (Senate) }\end{array}$ \\
\hline
\end{tabular}

Among my case study countries, Senegal is the one with the newest constitution,

and yet the one with the largest number of constitutional amendments (15). I consider ten of them to be non-consolidating. For procedural purposes, I discuss four amendments classified as non-consolidating for similar reasons together: the amendment number 2003-15 of June 19, 2003 that created the Republic Council for Economic and Social Affairs (CRAES); the amendment number 2007-06 of February 12, 2007, creating the Senate; the amendment number 2008-31 of August 7, 2008 suppressing the CRAES; and the amendment 2008-32 of August 7, 2008, creating the Economic and Social Council. The non-consolidating nature of these institutions resides in part in the historical context in which they were created. In 1998, President Abdou Diouf, by the constitutional law number 98-11 of March 2, 1998, created a Senate against the will of the opposition led by Abdoulaye Wade. The opposition was strongly opposed to the creation of a Senate. Abdoulaye Wade promised the Senegalese people to dismiss the institution once in 
power. Two years later, he became president and kept his promise. The Senate was removed. Wade thus took his revenge, but that is not the whole story.

The specific context of the amendments tell us more about their real political implications (see table 8 above). By removing the Senate, President Wade removed a good part of the opposition party, since the Senate was dominated by MPs from the party of former President Abdou Diouf. The Senate that disappeared in 2001 was recreated in 2007 (amendment number 2007-06 of February 12, 2007). Out of a total of hundred Senators, President Wade nominated 65, and the remaining seats were filled through indirect elections by an electoral college made up of MPs and local officials (Hesseling, 2010; Fall, 2012, p. 33). According to Cabanis and Martin (2005), the creation of Senates in the African context usually obeys the needs for politicians to offer their friends political offices in return for their support for unclean or illegitimate political maneuvers. This was the case for Cameroon in 1996, Côte d'Ivoire in 1998, and Togo in 2003. By nominating more than half of the Senators, President Wade's goal was to consolidate his grip on power. The real implications of the creation of the new institution is that Senators are given constitutional power to participate in the process of constitutional amendment. Needless to say, a sitting president in the African context I described above would not nominate opposition members who might vote against him. In other words, what is at work here is the informal practices of clientelism in which a politician offers goods and services for political support (Walle, 2003).

The creation and suppression of the CRAES happened in circumstances similar to the ones that led to the creation of the Senate under President Abdou Diouf: there was no consensus (Hesseling, 2010). The opposition Socialist Party (PS) was strongly opposed to 
it, but the party in power, the Senegalese Democratic Party (PDS) did not bother to reach out (Fall, 2011). President Wade created the CRAES and later removed and replaced it with a similar institution that has a different name: The Economic and Social Council (CES). The rational used to defend the creation of the CRAES is the same rationale that was put forward to explain the creation of the CES, which is to facilitate a social dialogue. Why remove one institution to create another institution when the only difference between them is just the name? Actually, there was more than the mere change of name according to Fall (2011, p.195). President Wade did not want M'baye Jacques Diop as the president of the CRAES anymore. He suggested that Diop resign, but Mr. Diop refused to do so. The President then chose to eliminate the entire institution to remove the head of the institution, Mr. Diop. The fact is that President Wade had already promised the presidency of the CRAES to Mrs. Aminata Tall, a longtime member of the PDS who became a dissident and whom President Wade wanted back into the party. The sitting president of CRAES, Mr. Diop was originally from the PS, the former party in power. He only joined President Wade and the PDS during the 2000 presidential runoff elections. Legally, President Wade could not remove him as he was supposed to serve as President of the CRAES for five years (Thiam, 2007, p. 150). President Wade then dismissed the entire institution to achieve his goal (Hesseling, 2010). Proceeding that way was much easier for the president, since his party had more than the required majority in the Parliament to amend the Constitution (see appendixes $8 \& 9$ ).

According to Hesseling (2010), the context of the four constitutional amendments, the reasons used to defend their necessity, and their real implications seem to confirm that they are all politically motivated. For instance, the official motivation for creating a 
Senate was that the institution would help consolidate democracy by reinforcing local representation. If this were the real objective of the amendment it seems contradictory that 65 of the Senators are chosen by the president and not by the people that they are supposed to represent. Moreover, the opposition led by Wade under President Diouf rejected a similar amendment in 1999 on the grounds that a senate was unnecessary and too costly for the country. The same opposition also boycotted the Senatorial elections arguing that the rules and settings for the election were too advantageous for the ruling party, although Abdou Diouf the former president only nominated 12 senators. When Abdoulaye Wade became president he took his revenge by dismissing the Senate and recreating his own in which instead of 12 he nominated 65 senators, five times more senators than President Diouf.

Besides the cost and the unnecessary nature of institutions such as the CRAES and the CES in a bicameral institutional environment, the non-consensual context of the creation of these institutions poses a serious problem of legitimacy and a problem of efficiency. To state it clearly, I am not doubting the importance of a Senate as a vital institution in the structure of constitutional democracy. The point is that a Senate and even the CRAES or CES can be useful institutions that can help consolidate democracy: however, the problematic context in which they were created not only undermines their efficiency, but it also makes them non-consolidating institutions (Fall, 2011). The consolidating democratic principle that I argue has been disregarded or violated in the particular context of these amendments is checks and balances of power. By packing the parliament with members of the same ruling party in the context of a strong presidential regime added to a widespread practices of clientelism, what is being denied to the people 
is the principle of checks and balances (Prempeh, 2010; Monga, 1999; Wantchekon, 2003).

Table 9: Amendments for revenge against the President of the National Assembly

Amendment 2007-26 of May 25, 2007 \& Amendment 2008-67 of 21 October 2008

\section{Specific context of the amendment}

- Since 2007, personal relationships between President Wade and the president of the National Assembly, Macky Sall were shaky (Fall, 2011, p. 192)

- The president of the National Assembly asked Karim Wade (the son of President Wade) to present an accounting of money spent for the organization of the Islamic summit that he led. President Wade was enraged (Scales-Trent, 2011, p. 92).

- President Wade was more than eighty year old and there was a probability that he would leave office before the end of his term in 2012

- The President of the National Assembly has been stripped of power to approve and sign constitutional laws (Fall, 2011).

\begin{tabular}{|c|c|c|}
\hline $\begin{array}{l}\text { Motivation for the } \\
\text { amendment }\end{array}$ & Principle in violation & Non-consolidating aspect \\
\hline $\begin{array}{l}\text { The president of the } \\
\text { Senate as the second } \\
\text { highest official is a } \\
\text { logical consequence of } \\
\text { the creation of a } \\
\text { Senate } \\
>\text { Need to treat all } \\
\text { legislators equally }\end{array}$ & $\begin{array}{l}\text { Separation and } \\
\text { balances of power }\end{array}$ & $\begin{array}{l}\text { Use of the } \\
\text { constitution for a } \\
\text { personal revenge } \\
\text { (getting Macky Sall } \\
\text { out for someone } \\
\text { who does not } \\
\text { challenge President } \\
\text { Wade) }\end{array}$ \\
\hline
\end{tabular}

Amendment 2007-26 of May 25, 2007 made the president of the Senate (instead

of the President of the National Assembly) the second highest ranking official in the country. Amendment 2008-67 of October 21, 2008 that I already described in the beginning of the chapter removed the five-year mandate of the president of the National Assembly. Based on unspecified troubled relationships between President Wade and the then president of the National Assembly, Macky Sall, Article 39 of the 2001 Senegalese Constitution that held the president of the National Assembly as the second highest 
official in the country was modified (Fall, 2011). According to the new law, the president of the Senate replaces President Wade in case of a vacancy. President Wade was more than eighty years old and there was a probability that he would leave office before the end of his term in 2012. As a matter of fact, while the President of the National Assembly Macky Sall was being deprived of his constitutional power in favor of the President of the Senate, the internal rules of the National Assembly were also being modified to strip him of his power to approve and sign constitutional laws. When in 2008, Macky Sall as President of the National Assembly asked Karim Wade, the son of President Wade, to present an accounting of money spent for the organization of the Islamic summit that he led, President Wade felt humiliated. He was enraged that the Parliament would dare to ask his son to appear before the National Assembly (Scales-Trent, 2011, p. 92). The immediate consequences were the removal of Macky Sall from the presidency of the National Assembly. Amendment 2008-67 of October 21, 2008, was passed and MPs voted to remove Macky Sall. Senegalese constitutionalists classify this amendment as revenge (Fall 2011). The different aspects of non-consolidating amendments summarized in table 13 say a lot about how constitutions are being used by West African politicians. Actually, in Senegal, there has never been a military coups-d'état; there are only constitutional coup-d'états. In this particular context one can safely say that in Senegal, constitutions do not limit the power of those who govern. Rather, constitutions are legal instruments in the hands of officials for personal use. This is what Kanté (1989) means when he says that Senegal is an example of stability and continuity, but it is also an example of constitutional instability. Based on the official motivations, it can be argued 
that there is no proof of bad intent behind the two amendments mentioned above. Moreover, they were done legally.

As a matter of fact, official motivations usually do not present all the practical implications of an amendment. The official motivation for making the president of the Senate the second highest official in the country only states that the president of the Senate is the second highest government official as a consequence of the creation of the Senate (Fall, 2007, p. 244). Such a statement does not provide sufficient information for anyone who is interested in understanding why instead of the President of the National Assembly (as stated in Article 39 of the initial constitution), the amendment makes the president of the Senate the second highest official. As mentioned above, there have been some internal ruling party disputes between President Wade and Macky Sall the president of the National Assembly. The draft of the amendment and the removal of the president of the National Assembly came right after the dispute and after Macky Sall requested that Karim Wade, the son of President Wade, testify about his use of public funds (Fall, 2011).

One might argue that the connection between the amendment to change the official protocol and the shaky relations between President Wade and Macky Sall is not obvious; however, one needs to remember the context. We are talking about a country where the use of constitutional amendments for personal revenge is known. President Diouf, when faced with a similar situation in 1984, had Habib Thiam, then president of the National Assembly, removed through a constitutional amendment. Once Mr. Thiam was removed from the presidency of the National Assembly, the article was reinstated exactly as it has been initially (Fall, 2011, p. 190). President Senghor used a similar 
manoeuver to remove his adversary and Prime Minister Mamadou Dia in 1962. An important fact that is worth mentioning is that Macky Sall, the former evicted president of the National Assembly, won the 2012 Senegalese presidential election and is the current president of Senegal. Karim Wade, the son of former Senegalese president Abdoulaye Wade is now in prison on charges of embezzlement. This seems to confirm the political nature of the amendments against the former president of the National Assembly who is now taking his revenge.

Actually, the official reasons for the amendments are neither clear, nor convincing. One thing that seems clear and convincing, however, is that President Wade and the ruling party disregarded the constitutional principle of separation and balances of power by removing the president of the National Assembly who was, according to the initial constitution, the second highest ranking official in the country and had a five-year mandate in such position. Non-commitment to constitutionalism and the informal use of the constitution for retaliation are the non-consolidating aspects I argue are behind Amendment 2007-26 of May 25, 2007 and Amendment 2008-67 of October 21, 2008.

Table 10: Amendments for overstaying a constitutional mandate

Amendment 2006-11 of January 20, 2006, \& amendment 2007-21 of February 19, 2007

Specific context of the amendment

- Senegal was less than four months away from legislative election (Fall, 2011.

- Unclear and confusing motivation for the amendments.

\begin{tabular}{|c|l|l|}
\hline $\begin{array}{l}\text { Motivation for the } \\
\text { amendment }\end{array}$ & Principle in violation & Non-consolidating aspect \\
\hline $\begin{array}{l}\text { Flooding and lack of } \\
\text { financial means. }\end{array}$ & $\begin{array}{l}\text { Commitment to } \\
\text { Constitutionalism } \\
\text { Senegalese electoral } \\
\text { code. }\end{array}$ & Overstay of MP mandate \\
\hline
\end{tabular}


Amendment 2006-11 of January 20, 2006, and amendment 2007-21 of February 19,2007 , that modified the previous amendment were both made to allow MPs to overstay their mandate. They were criticized by the opposition for being crafted to change the electoral schedule for political purposes (Fall, 2012). The Senegalese opposition suggested that these two amendments were a way for the ruling party to create uncertainty about the elections in order to win. The ruling party (PDS) and its affiliated parties ended up winning the 2007 legislatives elections 133 seats out of 150 . The point is that the two amendments by postponing elections successfully disturbed the electoral calendar and frustrated the opposition, which claimed to have been cheated in the whole process. As a matter of fact, the rationale for the amendment was not strong enough to convince an objective observer about the need to amend the constitution. According to the President who initiated the 2006 amendment, the amendment was justified by the heavy rain that forced many Senegalese out of their homes and that resulted in a government relocation program. Faced with these unusual circumstances, the government had to reallocate financial resources to deal with the crisis. Consequently, no money was left to hold elections as scheduled (Fall, 2011, p.154). President Wade then suggested that the constitution be modified in order to have both Presidential and legislative elections held altogether. This was the official reason for the January 2006 amendment. The mandate of the MPs elected on April 29, 2001, was set to expire on May 17, 2006. Meanwhile the President's party raised the number of seats in the National Assembly from 120 to 150 . These changes required some redistricting. Unsatisfied with the resulting redistricting, some opposition parties reached out to the Council of State that 
voided the redistricting law (on January 12, 2007) on the grounds that some demographic criteria were not properly taken into account.

President Wade saw an opportunity to take another bite at the constitution. He suggested amendment 2007-21 of February 19, 2007. This time the president proposed that the presidential election and the legislative elections be held on different dates. Unfortunately, the official rationale for the new amendment does not say where the government suddenly got the money to hold separate elections. As a reminder, the government argued earlier that it was postponing the legislative elections to have them held together with the presidential election because it had no money to organize them separately on time. A year later with amendment 2007-21 of February 19, 2007, the government argued it needed to postpone the same legislative elections to hold them separately from the presidential election. The initiators of the amendment argued that the presidential election according to Article 31 of the Constitution had to be held at the scheduled time. The legislative elections, however, could no longer be held at this time because there was not enough time for the declaration of candidature that was supposed to happen sixty days before the elections, according to Article 168 of the electoral code. Therefore, the legislative elections were to be held on June 3, 2007. All these confusing rationales make one feel that the constitution is just being toyed with. Notice that there is no more mention of a lack of funding for the elections as suggested in the initial amendment. The Senegalese executive had five years to get ready for legislative elections.

The rationale presented does not mention any effort on the part of the government to respect the elections timetable that is a constitutional commitment for any democratic 
country (Bratton, 1999). The 2007 law that modified the 2006 amendment states that the presidential election had to be held on time and that the legislative elections could not be held because of the provision of Article 168 of the electoral code. Since amendment 2006-11 of January 20, 2006, had already been passed to keep MPs in office, I argue that Article 168 could have been modified to hold both elections altogether as planned through amendment 2006-11 of January 20, 2006, if the government were serious about holding elections altogether to save money. The point is that Article 168 (that is now cited in the 2007 amendment as the reason for not holding the legislative and presidential elections altogether) is an article from the electoral code. If the government were serious about respecting its earlier amendment, it could have chosen to modify Article 168. An electoral code is hierarchically inferior to a constitution that is the supreme law. Therefore, if the ruling party can amend the constitution, it can also modify the electoral code. Not doing so shows the lack of sincerity that is the common denominator for all non-consolidating behaviors. The Senegalese authorities are using the electoral calendar for political gains. ${ }^{29}$

The particular context that makes Amendment 2006-11 of January 20, 2006, and Amendment 2007-21 of February 19, 2007, suspicious and non-consolidating of democracy is that they occurred a few months before the elections were held. Analysts (Fall, 2011; Bratton, 1999) argue that as elections approach, ruling parties in weak democratic countries engineer all kind of techniques to make sure they have an upper hand over the results. This is the main reason why the 2001 ECOWA (Economic

\footnotetext{
${ }^{29}$ I have already discussed earlier how manipulating the electoral calendar can be used for political gains (Bratton, 1999)
} 
Community of West African States) protocol ${ }^{30}$ suggests that no substantial changes to the electoral law be allowed within six months of elections, unless it is done with a popular consensus. The Amendment 2007-21 of February 19, 2007, was adopted less than four months before the Senegalese legislative elections on May 24, 2007. The amendment was not consensual as shown in previous paragraphs. The motivations for the amendment are confusing and not reliable. The two amendments show a non-commitment to constitutionalism as they legalized an overstaying of legislative mandates. Moreover, the practical implications of -a disturbed electoral calendar is known in the transition to democracy and democratic consolidation literature (cited in the beginning of this chapter) as a non-consolidating behavior of authoritarian regimes meant to secure elections.

Table 11: Extending the Presidential Mandate

\section{Amendment 2008-66 of October 21, 2008}

\section{Specific context of the amendment}

- The amendment of Article 27 was supposed to be done through a referendum

- The National Assembly was overwhelmingly dominated by the ruling party (131 seats out of 150)

\begin{tabular}{|c|l|l|}
\hline $\begin{array}{l}\text { Motivation for the } \\
\text { amendment }\end{array}$ & Consolidating Principle & Non-consolidating aspect \\
\hline $\begin{array}{c}\text { A longer presidential } \\
\text { mandate allows the } \\
\text { president to get his } \\
\text { multiple projects done. }\end{array}$ & $\begin{array}{l}\text { Commitment to } \\
\text { constitutionalism }\end{array}$ & $\begin{array}{l}\text { Unreasonable extension of } \\
\text { presidential mandate (Fall, } \\
2011,2012)\end{array}$ \\
\hline
\end{tabular}

Amendment 2008-66 of October 21, 2008, made the presidential mandate longer, taking it from five to seven years. Most democracies around the world have shorter presidential mandates (in most Anglophone countries, the presidential mandate lasts four years). France, whose model of governance is being adopted in most Francophone

\footnotetext{
${ }^{30}$ Protocol ASP 12/1/2001 signed in Dakar in 2001 (Fall, 2011, p. 197)
} 
countries, has had a five-year presidential term since 2000. The tendency around the world is to have a shorter presidential term in office (Fall, 2011). The presidential mandate always creates passionate debates during constitution-making in democratizing countries because it is considered an important constitutional principle to have a limited presidential term in office due to the hegemony of the executive power (Prempeh, 2010; Monga, 1999; fall, 2007; Walle, 2003). Once this key provision is included in the constitution, modifying it becomes suspicious when it is done through a National Assembly that is dominated by the ruling party. In Senegal, the amendment was easily passed through the parliament although Article 27 of the Constitution stipulated that this particular constitutional provision could not be changed without a referendum (Fall, 2011, p.59). This view is supported by Babacar Guéye and Demba Sy who together with three others drafted the 2001 Senegalese Constitution. President Wade and his experts in constitutional law found their way around the provision and amended the constitution without a referendum.

At the end of his second term, President Wade argued that the 2001 Senegalese constitution that limited the presidency to two terms in office could not apply to him as he held his mandate under the 1963 Constitution. Therefore, he could be a presidential candidate for two more terms after he ended his first two-term presidency under the 1963 Constitution. The Constitutional Council agreed on the grounds that the law is not retroactive. In other words, a law that was made in 2001 could not apply to a president elected in 2000. This decision of the Constitutional Council seems awkward, because Article 104 of the 2001 Constitution clearly states that the President could continue his current mandate to the end. The second clause of the Article says that all other provisions 
are applicable to the sitting president, which means that after a second mandate President Wade could not run for presidential elections again (Fall, 2011). Wade was allowed to run for reelection in 2012. The point is that President Wade was interested in holding on to power as long as he could. This is the logic that prevailed in Amendment 2008-66 of October 21, 2008, that extended the presidential mandate to seven years. In countries known for their strong executive powers and longer presidential mandates unlimited terms in office are undesirable because of the potential abuses of power. With longer presidential mandates presidents become all but kings with the only difference being that ruling by heredity is not allowed (Louis Blanc cited by Fall, 2011).

"We have seen that under the changes to the 2001 Constitution, the President is supreme over all other organs of government, and considers himself "infinitely eligible". Wade has also fueled the high degree of paranoia that surrounds his exercise of power by frequently appointing, then replacing, political appointees... But since Wade was elected president in 2000, in the past ten years alone he has had one hundred twenty-two ministers and six prime ministers, and has reorganized the cabinet seventeen times. The most recent reorganization was in June 2010. How could those appointees not be concerned about their survival in Wade's political world? (Scales-Trent, 2011, p. 95)

The amendment 2008-66 of October 21, 2008, if passed in a well-established democratic country, may not have raised any suspicion or any concern about a potential nonconsolidation of democracy, but in the context I just described, there seems to be good reasons to be alarmed. In ten years, President Wade has made more non-consolidating amendments than his two predecessors. This created a suspicious political environment as almost all amendments are initiated by the executive and they are mainly aimed at consolidating the grip on power of one person: President Wade endlessly increases his power over the legislative and the judiciary (Thomas \& Sissokho, 2005; Fall 2007, 2011, 2012; Scales-Trent, 2011). The motivation for the amendment in question seems very 
poor as an argument to extend a presidential mandate that was already set by the Senegalese fundamental law. Moreover, the amendment was done in a non-consensual political context. The real implication of extending a presidential mandate is that a president may stay longer in power even when he becomes very unpopular. This raises significant risks in democratizing countries where democracy is not necessarily the "only game in town" and can jeopardize peace when an unpopular president is seen as being in power forever. Most African constitutions have shorter mandates (Fall, 2012). By extending the presidential mandate, although the new amendment does not apply to President Wade, the non-consensual political environment of the amendment confirms the lack of commitment to constitutionalism as a democratic principle. The initial constitutional provision limiting the presidential mandate to five years was well accepted as five years seems to be the norms in Francophone West African constitutions (Fall, 2011).

Table 12: Creation of a Vice-Presidency

\section{Amendment 2009-22 of June 15, 2009}

\section{Specific context of the amendment}

- President Senghor used a similar maneuver to impose a new president when he was leaving office.

- President Wade was 85 years old and could leave office any time allowing his unelected vice-president to lead the country.

- President Wade was suspected of creating the office of Vice-President for his son.

\begin{tabular}{|c|l|l|}
\hline $\begin{array}{l}\text { Motivation for the } \\
\text { amendment }\end{array}$ & Principle in violation & Non-consolidating aspect \\
\hline $\begin{array}{l}\text { To better involve } \\
\text { citizens in public } \\
\text { affairs } \\
\text { To reinforce } \\
\text { democracy }\end{array}$ & $\begin{array}{l}\text { Commitment to } \\
\text { constitutionalism }\end{array}$ & $\begin{array}{l}\text { Use of the vice-presidency } \\
\text { to hold on to power after } \\
\text { leaving office }\end{array}$ \\
\hline
\end{tabular}


With the Amendment 2009-22 of June 15, 2009, an office for the Vice-President of Senegal was created. The rationale for the law states that the vice-president will be nominated by the president and will exercise the missions given him by the president. The vice-president can be fired by the president. He or she becomes the second highest government official according to the country's official protocol. The initiator claimed that the creation of this office was justified by the desire to get citizens involved in public affairs and to reinforce democracy in Senegal. But nowhere in the official motivation is there any mention of how the creation of a vice-presidency stimulates citizens' involvement in public affairs. The mission of the vice-president is not determined by the constitution, but rather by the president who decides what the vice-president does. This particular idea looks awkward. In constitutional democracy major institutions are part of the initial constitutional design that creates a republic (Elster, 1993). The vice-presidency is a major institution since the vice-president may at any time become the president of the country. For the creation of an institution as important as the vice-presidency, common sense would be for the ruling party to have a national debate in order to bless the new institution with the basic national consensus necessary for its legitimacy and efficiency.

In political systems that are constitutional, in which constitutions are taken seriously as limiting government and limiting the decision-making process they describe, important modifications in the political system need to be reflected in the constitution. (Lutz, 1994, p. 357)

Instead, President Wade and his party chose a constitutional amendment passed by a National Assembly dominated by his party (131 seats out of 150). For the sake of practicality a political regime with a president and a prime minister, there is no need for a vice-president unless the office is created to solve a political crisis. Looking at the nature of democratic political regimes, a vice-presidency usually exists in countries with 
monocephalic (presidential) regimes, not in countries with bi-cephalic regimes (Fall, 2011). There is already a panoply of institutions that make the role of a vice-president unnecessary in Senegal. Besides the Senate and the National Assembly, there is the CES with the mission of advising the president on important policies decision-making. Moreover, the Constitution has already taken care of the process of succession of the president in case of his unexpectedly leaving office (Article 39). This particular amendment is part of the non-consolidating manoeuvers by former presidents to control power after they are out of office. The proof of such a statement is given in another amendment introduced by the president on June 23, 2011, to remove the second round of the presidential election process and to have the president and the vice-president elected on the same ticket as in the US.

The way the electoral process usually works in Senegal is that presidential candidates are elected through a direct universal suffrage. In case no candidate obtains the absolute majority of the vote, a second round is organized between the two candidates who obtained the highest votes. With the new proposed amendment, the winner would only need more votes than the other candidates, even if that means only $25 \%$ of the total vote. An absolute majority is no longer required. This amendment was introduced only seven months before the presidential election scheduled for February 2012. It was done using what is known as the emergency procedure (which does not include extensive debate by MPs). Why introduce such an important amendment a few months before the presidential election? There is no need to answer this question because President Wade intention to preserve his power seems obvious from the political context at the time. President Wade was aware of his growing unpopularity, and he was trying to find a way 
to secure his stay in office (Fall, 2011, p.207). Informed of the president's maneuver, the Senegalese civil society, led by RADDHO (African Meeting for the Defense of Human Rights) organized public protests under the name $Y$ en a marre (enough is enough). The pressure from this movement became so intense that President Wade had to withdraw the amendment. Fall (2011) calls this mobilization of the Senegalese people against the amendment the birth of Senegalese constitutional patriotism.

The context for the creation of the vice-presidency matters in assessing its consolidating or non-consolidating nature. As summarized in table 12, President Wade was 85 years old and could at any time leave office allowing an unelected vice-president to lead the country. More disturbing to the Senegalese people was the fact that nobody knew who President Wade was going to choose as his vice-president. This fueled the rumors that the president was preparing Karim Wade, his son, to take power. Such suspicions make sense when one considers the setting of the new institution of the vicepresidency. The prospect of the president retiring is not trivial. As a matter of fact, this scenario happened before when President Senghor chose Abdou Diouf to replace him by adding a second clause to Article 35 of the constitution in 1976. Diouf became president without election and ruled the country for twenty years (Kanté, 1989). Senegalese opposition argued that it was a violation of the right of the Senegalese people to choose their leader since the people constitute the source of sovereignty for any constitutional democratic government (Cheramy, 1976).

The motivation for the amendment stating that the vice-presidency would allow a better involvement of the people in public affairs does not seem to make any sense when one looks at the practical implications, which are that a vice-president could be imposed 
upon the people with no elections due to the creation of a non-consensual institution. Such a vice-president could become president without legitimacy. The irony is that President Wade vehemently criticized a similar manoeuver when he was in the opposition (Fall, 2011). The author argues that this is a deliberate disregard of the Senegalese constitution for political purposes on the part of President Wade whose attempted amendment confirmed his determination to hold on to power. Aware of his unpopularity he proposed an amendment that would allow him and his unknown vice-president to be elected with no absolute majority as required by the initial constitutional provision. All he would need would be to come out ahead of other presidential candidates, which according to analysts was still possible due to the enormous advantages of incumbency in democratizing countries with weak democratic culture (Levitsky \& Way, 2010). 
Table 13: Summary of non-consolidating aspects of amendments

\begin{tabular}{|c|c|c|c|c|c|}
\hline Country & $\begin{array}{l}\text { Overstaying a Constitutional } \\
\text { Mandate }\end{array}$ & $\begin{array}{l}\text { Packing the } \\
\text { Parliament }\end{array}$ & $\begin{array}{l}\text { Amendment for } \\
\text { Clientelism }\end{array}$ & $\begin{array}{l}\text { Amendment for } \\
\text { Revenge }\end{array}$ & $\begin{array}{l}\text { Amendment for } \\
\text { securing Power after } \\
\text { End of Term }\end{array}$ \\
\hline $\begin{array}{l}\text { Burkina } \\
\text { Faso }\end{array}$ & $\begin{array}{l}\text { Amendment 002/97/ADP of } \\
\text { January } 1997 \text { (Extension of } \\
\text { presidential mandate) } \\
\text { Amendment 023-2012/AN } \\
\text { of May 18, 2012 (Extension } \\
\text { of MPs mandate) }\end{array}$ & $\begin{array}{l}\text { Amendment } \\
\text { 033-2012/AN } \\
\text { of June 11, } \\
2012 \\
\text { (Creation of a } \\
\text { Senate) }\end{array}$ & & & \\
\hline Senegal & $\begin{array}{l}\text { Amendment 2006-11 of } \\
\text { January 20, } 2006 \text { (Extension } \\
\text { of MPs mandate) } \\
\text { - } \text { Amendment 2007-21 of } \\
\text { February 19, 2007 } \\
\text { (Extension of MPs mandate) }\end{array}$ & $\begin{array}{l}\text { Amendment } \\
2007-06 \text { of } \\
\text { February 12, } \\
2007 \\
\text { (Creation of a } \\
\text { Senate) }\end{array}$ & $\begin{array}{l}\text { Amendment } \\
2003-15 \text { of } \\
\text { June 19, } \\
2003 \\
\text { (Creation of } \\
\text { the CRAES) } \\
\text { Amendment } \\
2008-32 \text { of } \\
\text { August } 7, \\
\text { 2008 } \\
\text { (Creation of } \\
\text { the CES) }\end{array}$ & $\begin{array}{l}\text { Amendment } \\
\text { 2008-31 of } \\
\text { August 7, 2008 } \\
\text { (Removal of the } \\
\text { president of the } \\
\text { CRAES) } \\
\text { - Amendment } \\
2007-26 \text { of May } \\
25,2007 \\
\text { (Removal of the } \\
\text { National } \\
\text { Assembly } \\
\text { President as } \\
\text { Number 2) } \\
\text { Amendment } \\
\text { 2008-67 of } \\
\text { October, 21 2008, } \\
\text { Shortening of } \\
\text { Macky Sall's } \\
\text { Mandate }\end{array}$ & $\begin{array}{l}\text { - Amendment 2008- } \\
66 \text { of October 21, } \\
2008 \text { (Extension of } \\
\text { presidential } \\
\text { mandate) } \\
\text { Amendment 2009- } \\
22 \text { of June } 15, \\
2009 \text { (Creation of } \\
\text { a vice-presidency) }\end{array}$ \\
\hline
\end{tabular}




\section{Conclusion}

In this chapter, I presented all the constitutional amendments made in my case study countries since the adoption of their respective constitutions. Benin experienced no amendment, while Burkina Faso had six and Senegal fifteen. Details are given in table 14 below. I identified thirteen out of a total of twenty-one amendments to be nonconsolidating amendments. I did so by relying on five indicators of democratic consolidation: the general context of governance in a given country; the specific context in which an amendment is made; the motivations for the amendment; the consolidating principle that the amendment can be tested against; and the non-consolidation aspect of the amendment. The general context of governance is an important indicator in my work, because non-consolidating constitutional amendments are prevalent in countries with specific characteristics that violate principles of governance considered necessary for democratic competition. That is why a similar amendment deemed non-consolidating in a democratizing country may not be considered so in a country with a well-established democratic tradition. The specific context of a given amendment sheds light on the real and practical implications of the law. Such practical implications are not always presented in the official motivation for the amendment. The motivation for an amendment is the official defense for a given law. By comparing the official argument for an amendment to the applicable constitutional principle, one is better positioned to say whether or not a given law is made to advance democracy. After analyzing an amendment in the light of the four indicators cited above, it becomes easy to point to the particular aspect in a law that is problematic in term of constitutional democratic practices. 
As a matter of fact, these problematic amendments, which I call nonconsolidating amendments, are not intended to reinforce democracy or the rule of law. Non-consolidating amendments are mainly designed to reinforce the political power of an individual or a group of individuals through targeted constitutional changes engineered to manipulate electoral and other political laws in favor of incumbent power-holders. The challenge in this chapter was to identify non-consolidating amendments and show why they were non-consolidating of democracy.

I first presented the unusual African political context in which non-consolidating constitutional amendments are made, a context where the executive branch dominates the other branches of the government. Moreover, the party that holds the presidency is almost always the same party that controls the parliament. The president's party usually has more than the required majority to amend the constitution. I discussed an electoral system that not only makes it easier for a single party to be over represented in the parliament, but also gives the president control over which candidate makes it to the legislative list ballots. This particular practice makes MPs vulnerable vis-à-vis the president and often pushes them to give the president a blank check for amending the constitution in exchange for their seat in the parliament. This is what Good (2003) explains in his analysis of South African elections:

The use of the party list system of proportional representation without constituencies or provision for by-elections, placed great preferment in the hands of the executive... Singularly and collectively, the ruling elite of Southern Africa have shown that their chief concerns are with self-interest and retention of power and constitutionalism counts for little. (p. 4). 
As I have shown, such practices vary among the three countries chosen for this study, allowing us to view them in comparative perspective as they reflect various levels of commitment to democratic principles.

Table 14: Number and percentage of amendments per country since the adoption of the current constitutions

\begin{tabular}{|l|c|c|c|c|}
\cline { 2 - 5 } \multicolumn{1}{c|}{} & $\begin{array}{l}\text { Year of } \\
\text { constitution } \\
\text { adoption }\end{array}$ & $\begin{array}{l}\text { Non- } \\
\text { consolidating } \\
\text { amendments }\end{array}$ & $\begin{array}{l}\text { Total number } \\
\text { of amendments }\end{array}$ & $\begin{array}{l}\text { Percentage of non- } \\
\text { consolidating amendments }\end{array}$ \\
\hline Benin & 1990 & 0 & 0 & $0 \%$ \\
\hline $\begin{array}{l}\text { Burkina } \\
\text { Faso }\end{array}$ & 1991 & 3 & 6 & $50 \%$ \\
\hline Senegal & 2001 & 10 & 15 & $67 \%$ \\
\hline
\end{tabular}




\section{Chapter IV: Openness of constitutional adoption process}

\section{Introduction}

Constituent assemblies or constitutional conventions, constitutional conferences, national conferences, representative legislative committees, constitutional commissions, transitional legislative models, and peace negotiations are some of the concepts used in the literature to talk about constitutional drafting and amendment processes (Fafard \& Reid 1991; Widner, 2005). As a matter of fact, the process that brings a constitution to life is vital and often dictates the nature of the constitutional document that is produced (Haysom 2007; Elster 1993, 1995; Santiso 1998; Banks 2008; Battharai \& Subedi 2007). The focus of this chapter is the process of constitution-making. I argue that an open constitutional adoption process (a transparent and inclusive process) will lead to a better substantial constitutional document; a document that is more consensual and that will therefore be owned and accepted by the parties involved (Akiba, 2004). My assumption is that a constitutional adoption process that is not inclusive and transparent would be viewed as illegitimate and troublesome for a country. In such conditions, a country is more likely to experience non-consolidating constitutional amendments mainly because of the lack of consensus during the adoption process and also because of the indifference citizens may show toward constitutional issues. This may give the government a free pass to engage in undue amendments, since the people who are excluded from the process would not feel any duty to defend or protect a constitution they did not own in the first 
place. I use two indicators to make my point about the openness of the constitutional adoption process. First, I discuss the importance of having an inclusive and diversified sample of participants in the constitution drafting process. Second, I show how sharing information about the adoption process makes a difference when it comes to transparency and the quality of the constitutional document produced at the end of the process. I show how important the sovereign conference was in the constitutional adoption process in Benin and how the lack of independence of the constitutional drafting body from the sitting regime had a negative impact on the outcomes of the processes in Burkina Faso and Senegal. I explain that in these two countries there was no national consensus on the constitutional document itself, not only because the internal process wasn't consensual, but also because the process lacked openness from the beginning. A constitutional drafting body that is controlled or numerically dominated by the sitting party, although its internal decision-making process may happen to be consensual, does not produce a national consensus. Basing my position on a concept of national consensus obtained through a free and inclusive popular participation, I argue that the availability of information to the public is not obvious in Burkina Faso and Senegal as the people were excluded from the beginning and did not take part in the process until the referendum that is the final step of the process. I conclude that the Beninese Constitution because of it inclusiveness and relative transparency is substantially better than the constitution of other two countries (table 15 below shows that only the Beninese constitution-making process satisfies my two criteria of transparency and inclusiveness). 


\section{Diversity of participants in constitutional drafting}

Before making the point regarding inclusiveness and diversity of participants in the constitution-making process, it makes sense to say a word about what a constitution is. What is so important about constitutions that makes their adoption such a particular event? Shortly defined, a constitution is the birth certificate of a country Verdussen cited in (Badet, 2009). It is a set of fundamental principles under which a state, an association or an organization is governed. Emphasis should be put on the words "fundamental principles" as constitutions are particular documents that usually require a particular process for their amendment, though this is not always the case. In New Zealand for instance, ordinary legislative process suffices to amend the constitution. Constitutions can be written or unwritten. The creation or adoption of new written constitutions usually happens under particular conditions such as a social or economic crisis, a revolution, a regime collapse, a fear of regime collapse, a defeat in war, a reconstruction after war, the creation of a new state, or the liberation from a former colonial power. This is what Elster (1995) calls waves of constitution-making. Regardless of the circumstances that lead to the creation of a new constitution, the main objective of a constitution is to provide the rule of law; a system of government in which everyone, including government officials, is subject to the principle of legality (Merryman, 1985).

It can be observed that my focus in this discussion is on liberal democratic constitutionalism, as there are totalitarian regimes that also use constitutions to govern their people (Bonime-Blanc, 1987). For the purpose of my study, I define constitution with an emphasis on the necessity of limiting state power by means of law, the reasoning for adopting constitutions being that no government should ever be given unlimited 
power over its people. In a simple sentence, constitution means limited government. A constitutional government is therefore, a government that exercises power according to the limitations defined in the constitution (Akiba, 2004, p. 5). Any other use of government power is a use of "power without right" (Paine, 1956, p. 302). As one can see, the people are at the center of any liberal constitution that is created to curb governments' potential abuse of power in order to protect the people's right. Moreover, by delineating the commonly held core values and "aspiration of the people of a given society, constitutions provide the citizenry with a sense of ownership and authorship, a sense that we the people includes me" (Hanna, 2011, p. 19). This expression, "we the people," is included in most modern constitutions to give a sense of unity and inclusiveness to the people in a given country.

As mentioned above, I am dealing with liberal constitution-making that intervenes in democratic regimes. Liberal democracies are characterized by a core principle of majoritarian decision-making (Lijphart, 1999). Should that majoritarian rule of decision making prevail in the constitution-making process? In other words, should a majority's will be imposed on others in the process of constitution-making? Here is an important and interesting question raised in the literature. In deeply divided societies and for the sake of peace, a consensual approach would necessarily be more effective in protecting minorities' rights than a winner-takes-all scenario (Hanna, 2011). Since constitutions are known to be successful when they are widely accepted as legitimate, the author suggests that constitution-making should be based on broad popular support from both majority and minority groups in a given country. Similar argument is made to account for the failure of the Nepalese 1990 Constitution (Lawoti, 2007, p. 34). The author suggests that 
majoritarian rule has hindered the consolidation of democracy and created instability in Nepal because the majoritarian decision-making process concentrated power within a region and social group in the country.

Another important query raised in the literature on constitution-making has to do with citizens' participation in the process. The emphasis that is put on the people through the famous expression "We the People" that figures in the first pages of most moderns constitutions suggests that citizens' participation in the constitution-making process is necessary. Because constitutions are made for the people in the first place, any constitution-drafting done without the people's participation is necessarily illegitimate and potentially troublesome for a country (Haysom, 2007; Ghai, 2007). Moreover, a constitution is a supreme legal document from which all legislations and regulations derive their legitimacy and power. Such an important document should be made to ensure justice and good governance for the sake of peace in the country. This is why all stakeholders at all levels must be involved in the process of constitution-making (Bhattarai \& Subedi, 2007). Actually, the new tendency is toward creating political frameworks that captures the ownership of all citizens in the constitution-making process (Akiba, 2004). This way of doing things establishes a fairer distribution of political power. Also, because voluntarily agreed outcomes are more stable and more lasting than imposed ones, promoting a wider stake-holding through the inclusion of minorities and ordinary men and women would help create the sense of ownership necessary to legitimate and protect the constitution (Haysom, 2007, p. 105).

I have been emphasizing how important it is that minorities and ordinary men and women participate in constitution-making. However, this has not always been a priority 
mainly because the entity (whether a constituent assembly constitutional convention, constitutional conference, national conference etc.) that drafts the constitution is usually set by an external creator. It can be either Congress, such as in the case of the 1787 U.S. Constitution, the King as in the case of the France's 1789 Constitution or by a president as it happens nowadays in many countries. These external creators that Elster (1995) calls upstream actors often try to control the constitution-making process so that the outcomes would be favorable to them. According to the author, the Continental Congress instructed the Federal Convention to suggest changes to the Articles of Confederation, whereas in France, some delegates came to the convention with instructions to vote for an absolute veto for the king. In both cases, the drafters ignored instructions they were given. As a matter of fact, a document produced by a drafting body can only be viewed and accepted as legitimate if that drafting entity itself has come into being in a legitimate way (Elster, 1993). A constituent assembly whose members have merely been appointed by the president or any single ruler does not pass this test of legitimacy. Moreover, there should also be a process legitimacy. In other words, if the internal decision-making process is not perceived by all stakeholders as fair and democratic, the resulting document might be rejected as undemocratic and illegitimate. In this line of reasoning, a constitution that is shaped by military force or threat from the military will necessarily lack legitimacy

The point made by Elster (1993 \& 1995) is that by definition, the old regime is part of the problem that the constitutional convention is called to solve. There would be no need for any convention if the old regime were wise and were not flawed. If the old regime acknowledges (by convening a convention) that it is flawed, why should its instructions matter anyway? The lesson to be drawn from this analysis is that 
constitutions made based on the unwise instructions of an old regime are potentially highly problematic compared to those in which the drafters happen to overcome the imposed instructions from the old regime. This particular reasoning has been used by several scholars and writers to make the point about the relatively successful constitutionmaking process in Benin (Loada, Badet \& Fall, 2008: Santiso, 1998; Nzouankeu, 1993; Adamon, 1994). Actually, the more or less consensual nature of the constitution-making process in a given country is a determinant factor in how resilient a constitution will be against undue amendments. In other words, the more consensual a constitution is the harder it will be to amend it for political purposes (Loada, Fall, \& Badet, 2008).

This is the case for the Beninese Constitution that has not been modified since its adoption in 1990. Proof that the Beninese Constitution is considered consensual due to its adoption process was given by the Constitutional Court in 2006 when the National Assembly members voted 71 out of 83 for a one year extension of their mandate, arguing that they would save money for the State by simultaneously having both legislative and communal elections. On July 8, 2006, the Constitutional Court voided the amendment in these terms:

In accordance with the provision of Article 80 of the December 11, 1990: ... Given the fact that the four year tenure which is a constitutional established fact is the result of a national consensus ...the safeguard of the legal security and the national cohesion impose that all amendments take into account the ideals that led to the adoption of December 11, 1990 Constitution, especially the national consensus, a principle of constitutional value... (Loada, Fall, \& Badet, 2008, p. 15).

The importance of consensus during the constitutional adoption process is also shown in another event when in 2005, a year before the end of his presidential mandate, President Kérékou did not clearly express his desire to leave office. Rightly or wrongly, 
many Beninese assumed that they president wanted to modify the constitution to stay in power. Thirty associations and network of associations promoting human rights created a civil society movement that pressure President Kérékou to indicate in July 2005 that he was not interested in overstaying his mandate (Adjovi, 2006). Other examples of public outcry in support of the Beninese constitution can be cited. Because of the consensus reached during the adoption process, the Beninese people feel a sense of ownership toward their constitution that they are prompt to defend. Now, what makes the Beninese constitutional adoption process more consensual and more legitimate when compared to the situation in Burkina Faso and Senegal, which both experienced unilateral constitutional adoption processes?

In December 18, 1989, President Kérékou, by a decree ${ }^{31}$, created a national committee in charge of preparing the national conference. The committee was composed of eight ministers from President Kérékou's government. Because the committee was created by the current regime, many Beninese were suspicious about the good and real intentions of President Kérékou to hold a sincere national conference that would produce real political reforms. The first act of the committee was to issue a press release inviting political associations, professional, religious and social organizations, and any Beninese willing to contribute to the democratization process of the country to send their concerns in a written document to the committee. 487 letters were sent to the committee, some were sent to make suggestions, while others were sent to inform the committee of intent to participate to the national conference. Of these 487 letters, 203 came from individual citizens, 57 were from political associations, 64 from regional development associations,

\footnotetext{
${ }^{31}$ Decree N: 89-434 of December 1989
} 
15 from religious groups, 64 from workers unions, 61 from what was called other associations (Beninese Red Cross, youth associations, political refugees), and 23 from Beninese living outside of the country and from embassies. The committee decided on its own to add 86 delegates representing peasants from the country's 86 districts. Following the publication of the list of participants on February 1, 1990, there was an outcry of the people against the quotas that some viewed as too favorable to the current party in power. The party was given fifteen seats while other political parties were only given two seats each. On February 8, 1990, even though the committee initially said that the list and quotas were definitive, it managed to come up with a new list that only gave 2 seats to the current party like the others political parties. The new list is made up of 488 delegates. The committee led by lawyer Robert Dossou has the merit of inspiring the Beninese to get involved in the constitution-making process by inviting people to submit written statements about their views on the past, present, and future of the country. These documents were used as the first input and basis to start the national debate whose ultimate outcome was the Beninese Constitution (Adamon, 1994).

After the opening speech of President Kérékou on February 19, 1990, the 488 delegates elected a three-member interim committee to conduct the elections for the committee that would lead the national conference. On February 20, thirteen delegates, led by the archbishop Isidore de Souza, were elected to conduct the national conference. On the 21rst of February 1990, President Kérékou paid a quick visit to the conference and suggested he was ready to make some changes in his administration at the ministerial level, but he made it clear that he was never going to resign from the presidency (Adamon, 1995 p. 56). The conference, even with no elected mandate from anybody, 
proclaimed itself sovereign and proceeded to suspend the constitution, and dissolve the National Assembly. It also adopted plans for multiparty elections, and chose Nicephore Soglo, a former World Bank official, as Interim Prime Minister (Robinson, 1994). President Kérékou was allowed to stay in office until the next elections, but as we can see, he was stripped of his most important executive powers. On December 2, 1990 the constitution was approved with $96 \%$ of the vote. A year later, when the first multiparty elections took place, Nicephore Soglo became the first democratically elected Beninese president.

The process I just described is different from the unilateral constitutional adoption process used in Burkina Faso. In Burkina Faso, the idea of creating a constitutional commission to lead the drafting of a new constitution came from the Popular Front's meeting held in Ouagadougou from the $1^{\text {st }}$ to the $4^{\text {th }}$ of March 1990. The Popular Front, is a revolutionary movement led by then Captain Blaise Compaoré, Burkina Faso's sitting president who came to power on October 15,1987 , through a deadly coup d'état that ended the ruling of Captain Thomas Sankara. From the beginning, President Compaoré's revolutionary movement made it clear that the constitutional commission is all but an ad hoc commission created by the Popular Front executive committee and working under its directives (Ye, 1995). The mission of the constitutional commission was to provide a first draft of a constitution that would be submitted to the officials of the Popular Front. However, the commission was open to national political organizations and experts. According to Ye (1995), participation in the commission was controlled by the Popular Front. ${ }^{32} 104$ members of the commission including sixty four from the ruling party of

\footnotetext{
${ }^{32}$ In his 1995 book page 34, Ye writes that "it is worth noting that the Popular Front had identified two political organizations that could be invited to take part to the commission..." This quote I translate from
} 
President Compaoré, took part in the writing of the draft of the constitution. Four delegates belonged to political organizations, thirteen came from workers unions, nongovernmental organizations had two delegates, and four delegates represented religious communities. Seventeen experts (jurists, economists, scholars...) were part of the constitutional commission created by decree on April 20, 1990. ${ }^{33}$ This particular decree specifically mentions that the president and vice-president of the commission are necessarily members of President Compaoré's party. Moreover the decree emphasizes the fact that the commission has to work under the directives put forward by the Popular Front and that it has to work based on the initial input and documents provided by the president's party. On May 12, 1990, President Compaoré gave an opening speech and the commission was set to begin working. On September 27, the commission held its last meeting, and on October 14, 1990, the final draft of the new constitution was handed to President Compaoré.

On December 14, 1990, a national conference was held to discuss the final draft of the constitution. Around 2000 delegates from 30 provinces in the country were invited according to unspecified criteria set up by the party in power to amendment the drafted constitution. Amendments made by the conference mainly addressed revolutionary and anti-imperialist concepts of that were removed from the constitutional document. The final constitutional draft was then ready to be put to a referendum that was held June $2^{\text {nd }}$ 1991. Of the $48.65 \%$ of voters that took part in the referendum, $93 \%$ voted yes. Unhappy with the way, the constitutional adoption process was being conducted, newly created

French proves to what extent the participation in the drafting of the constitution was controlled by the ruling party.

${ }^{33}$ Kiti n: an VII 0279/FP du 20 avril 1990 
political opposition parties got together in a coalition called Coordination of Democratic Forces (CFD) to request from the Compaoré regime a national sovereign conference. They also wanted legislative elections to be held before the presidential election. They wanted Burkinabe from outside the country to be allowed to vote in these elections. On September 30 and October 7, 1991, they organized protest movements in the country's two main cities, Bobo and Ouagadougou. In October 1991, the Compaoré regime and its affiliated party members organized a demonstration against any national sovereign conference on the ground that Article 172 of the newly adopted constitution stated that the Compaore regime would be responsible for leading the transition until a new government could be set. None of the opposition's wishes were fulfilled before the presidential election that was held on December 1, 1991, and won by sitting president Compaoré with only $25.12 \%$ participation. After the presidential election and because of tensions between the opposition parties and the Compaoré regime, the newly elected president suggested the idea of a national forum for reconciliation. In February 1992, President Compaoré gave his opening speech at the National Reconciliation Forum in which 348 people took part. Due to a debate that emerged during the Forum on the issue of transparency, President Compaoré adjourned the forum. Some participants requested that national media be present to witness the event. Others opposed the suggestion on the grounds that it might incite violence.

The process in Senegal was unilateral but different from the one used in Burkina Faso. Senegal is famous or infamous for the frequency of constitutional amendments in the country (Fall, 2011). According to Marina Ottaway cited in Scales-Trent (2011), it is difficult to think of a constitution that has been amended more often than the Senegalese 
Constitution. Actually, while other African countries used military coup-d'états to solve political disputes, the Senegalese use constitutional amendments instead. The first major political crisis in the newly independent Senegal in December 1962 opposed President Senghor and Mamadou Dia, the president of the Council of Ministers. It was solved with the law $62-62$ of December 18, 1962. The law was introduced to temporarily amend the constitution in order to make President Senghor the only chief of the executive power (Fall, 2011, p. 126). In 1963, a new constitution was introduced to definitively change the Senegalese regime from parliamentarian to a presidential. In 1984, due to internal disputes in President Abdou Diouf's Socialist Party, a constitutional amendment was made aimed at Habib Thiam, then president of the National Assembly. The tenure of the National Assembly presidency was reduced from five to one year, and the law was immediately applicable to the sitting president of the National Assembly Habib Thiam who ended up being removed. After he was removed, the law was reinstated in its initial form (Diop, 2009). President Wade and his Senegalese Democratic Party (PDS) used a similar politically motivated amendment of the constitution to remove the now sitting Senegalese President Macky Sall who was then president of the National Assembly. After Mrs. Sall asked Karim Wade, President Wade's son to present an accounting of the money spent for the organization of the Islamic summit he led in 2008, President Wade felt insulted and had Macky Sall removed using a constitutional provision (Scales-Trent, 2011). Actually, the executive branch in my case study countries is very powerful due to their presidential regime type.

This particular type of regime became so unpopular in Senegal that a presidential candidate, namely Abdoulaye Wade then an opposition party leader, made it a campaign 
promise to move the country from a presidential regime toward a parliamentarian regime. Wade won the election on March 19, 2000, over President Abdou Diouf the second president of the independent Republic of Senegal. As much as the Senegalese people were happy about the political change they had just experienced, their expectations were also high when it comes to the new path along which they wanted the newcomer to take the country. The people were in the mood for a real change and the new president was eager to deliver his campaign promise for regime change in Senegal, a change that would happen by wiping the slate clean in order to set up a new style of government (Ngenge, 2010). The newly elected president had two main options for carrying out his promise to the people. The first one was either a major or a minor reform to the 1963 constitution. The second one that which could be seen as a more radical approach was to write a brand new charter from scratch. Because of the political mood at the time, the country wanted a radical change; President Wade was set to deliver a new constitution not only because this option corresponded to the post-election mood, but also because it would have been too hard a battle to win if President Wade had wanted to get the 1963 constitution amended through the National Assembly, where the old regime of the Socialist Party (PS) had a parliamentary majority. According to Article 89 of the Senegalese constitution in use the prerogative to initiate constitutional amendments was split between the executive branch and the parliament. A proposed amendment could become law after a referendum vote or a positive vote in both houses of parliament should the president choose not to use a referendum.

From a procedural perspective, writing a new charter was not the easiest option for the new regime either. In case the new regime chooses to write a new constitution, 
one of the options is to create a constituent assembly that would be made up of the members of the National Assembly as was the case when the 1959 constitution was adopted. This option would still not have been safe for President Wade as the opposition party held the Parliament. The other option left was for the new regime to get the green light from parliament to initiate a process of new constitutional adoption. Either way, President Wade had to deal with the opposition-held parliament. By decree n: 00/372 of 19 May 2000, President Wade initiated a technical commission led by the Senegalese Minister of Justice with the mission to draft a new constitution (Ngenege, 2012). The composition of the commission is as follows: two university law professors (Babacar Guéye and Pape Demba Sy); a lawyer representing President Wade (Madicke Niang); a magistrate representing the government and chosen by the prime minister (Taifour Diop); a notary representing civil society (Papa Ismael Ka). This five-member technical commission was given directives by President Wade as to what the main structure of the constitution should look like. According to Fall (2009), President Wade personalized the Senegalese 2001 constitutional adoption process as he controlled everything from the beginning to the adoption in January 7, 2001. The first draft was submitted to an interministerial council headed by the Prime Minister, the Presidents of the Senate and National Assembly, and all political parties. These key actors have fifteen days to propose amendments to the draft, and based on the suggestions of amendments made, the commission would submit a final draft to President Wade, who alone is empowered by the constitution to call for a referendum. On November 9, 2000, the Constitutional Council gave its favorable opinion to allow the new constitutional adoption process to pursue its course. The campaign of awareness before the adoption of the new constitution 
was very short, and it was made unimportant not only because of the political capital of the newly popular elected president, but also because the major political parties in the country adhered to the new document. Only one major party (the African Independence Party) and three other parties; the Jef Jef Alliance, the MDS (Movement for Democracy and Socialism) Naxx Jarinu and the PIT-Senegal (Party of Independence and Labour) were for the boycott of the constitution (RADDHO, 2001). ${ }^{34}$ On 7, January 2001, the Senegalese Constitution was approved through a referendum with $94 \%$ of voters in favor.

\section{Information and transparency of the process}

Procedure matters. If the internal decision-making process of the body that is chosen to draft the constitution is viewed as undemocratic, the document produced from such process would lack what Elster (1993) calls process legitimacy. In other words, information-sharing about the adoption process makes a difference when it comes to transparency and the quality of the constitutional document produced at the end of the process. However, the choice of open versus closed proceedings has its pros and cons. In a public process of constitutional adoption debate, delegates might be eager to show that they champion common good, making them unlikely to engage in logrolling or any type of compromises (Macey, 1986). In these kinds of situations delegates don't negotiate. Actually, they talk to the media instead of talking to each other (Haysom, 2007; Banks, 2008). The worst thing that can happen is that because of the public settings in which people are watching or listening, the delegates might adopt rigid and inflexible positions

\footnotetext{
${ }^{34}$ RADDHO means; La Rencontre Africaine pour la Défense des Droits de L'Homme (African Meeting for the Defense of Human Rights )
} 
and refuse to consider changing their position during the discussion even when someone else offers a better proposition than their own. The truth of the matter is that flip-flopping is not viewed as a moral virtue even though it can be a valuable behavior in a pluralistic society where compromises are necessary for the government to function. This is the point that James Madison was making when he suggested the following:

Had the members committed themselves publicly at first, they would have afterwards supposed consistency required them to maintain their ground, whereas by secret discussion no man felt himself obligated to retain his opinions any longer than he was satisfied of the propriety and truth and was open to the force of argument (Cited in Elster, 1993, p.181).

The author was quick to add that Madison missed the other part of the argument. He suggests that if the Philadelphia convention were being held today in the same conditions of secrecy as in the $18^{\text {th }}$ century, it would certainly be viewed as undemocratic and nontransparent. Actually, the biggest danger of secrecy is the lack of legitimacy of the entire process and consequently the illegitimacy of the outcomes. A good illustration of the problem caused by the choice of secrecy was made by Cohen (1991) about the lakeside conclave on the amendment of the Canadian Constitution in 1987. Prime Minister Mulroney convened the premiers of the ten Canadian Provinces and decided to keep them isolated from their advisers in order to pressure them to get a deal. This attitude was not well received by the public and later undermined the legitimacy of the discussion's outcomes. As a remedy to the perceived lack of democratic process and transparency, a number of alternatives have been suggested, among which are the use of constituent assembly and public hearings (Fafard \& Reid, 1991).

The key issue at stake here is transparency. What is viewed as fundamental to the concept of transparency in the constitutional adoption literature is mostly about the 
decision-making process during the constitutional drafting time period. Most authors writing about the African experience emphasize adoption of decisions through consensus instead of majoritarian type of decision-making (Bhattarai, 2007; Haysom, 2007; Ghai, 2007; Ebrahim, 2001; Mugwannya, 2001). It is not only about popular participation, it is also about people knowing how the outcomes are reached. However, and according to Yash Ghai the chairman of the 2010 Kenyan Constitutional review commission, consensus is not unanimity. "If $70-80 \%$ were for anything, that was enough...to move to voting... in our case, a two-third majority was accepted as necessary for making decisions" (Ghai, 2007). One of the most important aspects in "successful" constitution making is that the constituent assembly or whatever body is chosen to lead the process should have full control over its internal decision-making process. When the rules are set from outside, the process is necessarily viewed as lacking legitimacy. In the case of the 2010 Kenyan Constitution, internal decisions-making was the constituent assembly's business. The reason, according to Ghai (2007), is that a constitution is not a contract between the people and the rulers. Rather, it is a contract among the people, and government is just a delegate of the people, elected to apply the contract.

To reach a higher degree of transparency, a country such as South Africa chose for a constitutional assembly to lead the constitution-making process. However, having such a drafting body is not enough; there should be openness at every step of the process. Openness can be reached through participatory democracy (Ebrahim, 2001). According to the author, the participatory type of constitution-making process is meant to reassure people and create the trust that is necessary to legitimate the final document of the constitution. The South African constitutional assembly was successful in doing exactly 
that by creating a program of awareness and engaging the public. The program of awareness had three components: community liaison, media liaison, and advertisement. The constitutional assembly initiated interactive face-to-face meetings between members of the assembly and the public to educate about the process and receive input. The assembly established a department of media that used prints, radio, television, and a national advertising campaign. It also initiated an official newsletter called constitutional talks, an eight-page publication that presented materials in an educative manner. The constitutional assembly's meetings were reported to the public through all sources of media. Documents on the process and the first draft of the constitution were translated into eleven different languages and distributed to the public, and a national constitution week was initiated. Because people in rural areas do not always have access to media, constitutional public meetings were held to inform the public and get input from rural communities. What is more important is not so much the input of the rural community, but rather the act of participation and the sense of ownership of the whole process that follows (Haysom, 2007). This sense of ownership contributes to the legitimacy of the process and consequently the legitimacy of the outcomes (Biggs, 2001; Ebrahim, 2001; Haysom, 2007).

As a reminder, the overall goal of chapter IV is to show that constitutional adoption process matters and that the openness and the transparency of such process lead not only to a more substantial document, but also that a democratic constitution-making process helps build trust (among stakeholders) that is necessary for the legitimacy of the constitution. Actually, legitimacy is a key factor that can shield the constitution and protect it against politically motivated amendments. There are two reasons for this claim. 
The first one is that when the constitution is considered legitimate it is usually due to the adoption process that created trust, respect, and ownership of the final document. In such conditions, citizens themselves become a shield against politically motivated amendments to the constitution. Because they consider the constitution as their own, they would feel the duty to defend and protect it. An illustration of this particular reasoning was given above about the Beninese constitution through the civil protest now known as "hands off my constitution." The second reason for my claim that legitimacy constitutes a shield against undue amendments is related to the strength of the institutions created through a legitimate constitutional adoption process. When there is openness, transparency and consensus during the adoption process the resulting document is one with strong institutions, institutions with provisions that guarantee protection of the constitution against politically oriented amendments. Illustration of this particular reasoning will be provided in the next two chapters on the mechanism of constitutional amendment and the independence of the constitutional court.

My specific goal in this section is to examine the constitution-making processes in the three case study countries to see whether the public was well informed about the constitutional adoption process. More importantly, I want to know whether measures of public awareness taken by officials during the constitutional adoption process were sufficient to create the public trust and ownership of the constitution that is necessary to legitimate and defend the outcomes of the process. The brief review of the African constitution-making literature done above, points out some keys elements that can be considered ultimate conditions for public trust and ownership of a constitution in a given country. One of them is the openness of the process through availability of information to 
the public. Another one is consensus decision-making during the whole process. Consensus builds trust and prevents frustrations and rebellion. More importantly, consensus delivers legitimacy, a key element for public ownership and confidence in the fundamental law. The literature review also shows through specific examples (South Africa and Kenya) how availability of information to the public could be measured. My mission in this section is to show how my case study countries fare on these key elements.

It can straightforwardly be argued that in the Beninese case, the public was relatively well informed about the process and also about the substance of the constitutional document. Actually, the Beninese people were involved in the process from the beginning (Creevey, Ngomo, \& Vengroff, 2005). The committee initiated by president Kérékou on December 18, 1989, was quick to ask general public submission of written statements about the new direction of the country. Although the Beninese were skeptical of the intentions of president Kérékou, for he had nominated eight of his ministers without any public consultation, people still made submissions: 487 letters. The initial committee in charge of organizing the national conference reached out to peasants in rural areas and included 86 delegates from this often underrepresented part of the society in political decision-making. The first draft of the constitution (167 Articles) included input from the 487 written submissions. After the first draft was ready, a national committee for the vulgarization of the constitution was instituted on 14 June 1990. Six committees represented the six departments (Atacora, Atlantique, Borgou, Mono, Oueme, and Zou). These committees were in charge of training people who in 
turn would be going to explain the constitution to peasants and other citizens in order to get their opinion before the final draft (Adamon, 1995).

In Burkina Faso, the approach was different. The initial input that was used as the basis for writing the first draft of the constitution was given to the constitutional commission by the Popular Front (the president's party). Nowhere were peasants mentioned as participants in the initial draft. In other words, there was no particular effort from the sitting regime to include the broad population in the initial phase of the constitutional adoption process. There was no national awareness campaign or initiative before 14 December 1990 when a national conference was called to amend the first draft. Based on the very few and non-substantial amendments that were suggested during the conference (Ye, 1995), it can be argued that the draft was not well-known and understood by the people who were supposed to amend it, unless the 2000 delegates convened without clear criteria for their selection methods were mainly supporters of the sitting regime. Moreover, the only campaign with the mission of explaining the constitution to the people was initiated and conducted by President Compaoré's party. Opposition parties newly created with no financial means did not take part in the vulgarization of the constitution which adoption process they denounced from the beginning for being too tightly controlled by the regime in power. In other word, there was no openness or transparency compared to the Beninese process.

The constitutional adoption process that was used in Senegal was particular in genre compared to what is known of Benin and Burkina Faso. The Senegalese used a technical commission to write the first draft of the constitution based on directives received from newly elected President Wade. Individual citizens were not invited to take 
part in the initial process, neither were political parties involved in the first draft. Political parties were only called upon to submit amendments after they were faced with an initial document. Of course there had been some background negotiations before the initial document was produced, but officially no citizens or political parties were involved in the first phase of the process. There was no sign of a particular effort made to associate the public to the process by the new regime. The public was only called upon during the last stage of the process: the referendum. According to the African Assembly for the Defense of Human Rights, RADDHO (2001) the campaign for vulgarization of the Senegalese 2001 Constitution was made unimportant because the country's major political parties adhered to the document. Consequently, there was no major concern about getting the public on board or taking enough time to explain what the constitution was about, and how it came to be. In other words, it all happened as if there were hidden deals among parties and citizens were kept away from a not so transparent process of constitutional adoption in Senegal.

Table 15: Openness of constitution-making process by country

\begin{tabular}{|l|l|l|l|}
\cline { 2 - 4 } \multicolumn{1}{c|}{} & Constitution adoption & Diversity of participants & Transparency \\
\hline Benin & 1990 & Yes & Yes \\
\hline $\begin{array}{l}\text { Burkina } \\
\text { Faso }\end{array}$ & 1991 & No & No \\
\hline Senegal & 2001 & No & No \\
\hline
\end{tabular}

\section{Conclusion}

The initial assumption in this chapter is that the openness and the transparency of constitutional adoption process provide for a stronger and substantially better constitution. The reasoning is that an open and transparent adoption process creates an 
environment that allows a diversity of participants in the constitutional debate. A strong debate in which ideas are freely exchanged and discussed is more likely to deliver better outcomes. More importantly, a constitutional document that is achieved in such conditions is less likely to be rejected by any stakeholders or the people. In other words, a constitutional document that is born from openness and transparency is more likely to receive the seal of legitimacy, a key factor that serves as a shield against any politically motivated amendment. As a reminder, the focus of my dissertation is to research and understand why there are so many constitutional amendments in democratizing Francophone West Africa. I am particularly interested in enumerating the factors that can help protect against undue or politically motivated constitutional amendments. Openness and transparency of the constitutional adoption process is one of them. Actually, the point that I am making in this chapter is that the way a constitution is adopted is itself a major factor in protecting the fundamental document against non-consolidating amendments. A strong document is one arrived at through a minimum consensus, and that consensus becomes a constitutional principle that shields the documents against any vicious revision (Badet, 2009). This is what happened in Benin but did not happen neither in Burkina Faso, nor in Senegal. How do I show that this is the case for Benin, but not for the other countries? How do I prove that this particular factor of openness explains the fact that the Beninese constitution has never been amended since its adoption in contrast with the amendment histories of the Burkinabe and Senegalese constitutions? I make this claim based on three major factors. The first is the sovereignty of the conference that drafted the constitution. The second factor is the shield of constitutional protection offered by the 
consensual sovereign conference and the third one is the strength of the Beninese institutions resulting from the consensual conference.

The old regime that initiates a new constitution always seeks to control the constitution-making process in order to make the outcomes more favorable. However, because the old regime is part of the problem that the new constitution is meant to fix, overcoming the old regime directives or orders is the first thing a constitutional drafting body should do to be successful. This is what the U.S. 1787 constitutional convention did (Elster 1993: 1995). The Beninese National conference conducted itself in a similar fashion. Against the will of President Kérékou who shown up in the conference room on February 21, 1990, to make it clear that he was ready to make some changes at the ministerial level of his administration in order to deal with the crisis in his country, the conference declared itself a sovereign conference and went on to suspend the old constitution and strip Kérékou of his major powers. This was a turning point in the country's history. Once the conference was declared sovereign, it was free to deliberate, and its decisions were imposed upon President Kérékou. This did not happen in the other two countries included in my study. In Burkina Faso and in Senegal the authorities had control over the whole process of constitutional adoption. Studies of national conferences in eleven African countries show that countries were more or less successful in their transition to democracy depending on how the old regimes controlled or not national conferences (Santiso, 1998). The point is that the success of the Beninese experience is attributed mostly to the wise decision to ignore advice or recommendations from the old regime in order to decide freely about the future institutions to be created through the constitution. According to Santiso (1998), African leaders quickly learnt from the 
Beninese example and most national conferences taking place after the one in Benin were tightly controlled by dictators who often ended up staying in power.

The sovereign conference offered a shield against undue amendments to the constitution. As previously stated, the Beninese Constitutional Court, set a precedent in 2006 when the National Assembly voted to overstay its mandate. The Court's argument was based on the national consensus that led the country to democracy. According to the Court, because of the spirit and ideal of the national consensus that created the constitution in the first place, it would be seen as betraying that consensual ideal if the National Assembly could get away with an amendment as vital as overstaying its mandate. By establishing the national conference consensus as a principle of constitutional value, the Court suggests that from now on any amendment to the constitution could only be taken seriously if and only if the amendment fit the spirit and ideal of the national consensus from which the new country of Benin was born. This is a very high standard for constitutional amendments that the Court has set, and my point in using this example is that the Beninese Court wouldn't have had such a solid argument if the national conference has not been held in open and transparent conditions. Moreover, it is not just the Court that believes in the national consensus. The Beninese people also do. The proof was given when, in 2005, President Kérékou, a year before his last presidential term, was suspected of having intentions of overstaying his mandate by amending the constitution. Even though President Kérékou never officially said that he wanted to seek a third term, rumors that this suspicion created provoked an outcry among civil society organizations. Thirty-three associations promoting human rights organized a major campaign whose main message was "hands off my constitution." The president 
was then forced in July 2005 to make a public announcement stating that he had no plan for reelection. The point is that Beninese citizens were empowered by their national conference, and that it is being used as reference to defend the Constitution and oppose any malicious amendment. This is so because the people took ownership of the constitution that they felt bound to protect. Such an opportunity was given neither to the Burkinabe nor to the Senegalese who were not part of the constitutional adoption process until the last step (the referendum). Consequently, they do not feel as strongly as the Beninese about the ownership of the constitution and the duty to protect a product of which they were not midwives in the first place.

The third point to be made about why the constitutional adoption process matters is that the sovereignty and the freedom of Beninese national conference allowed the delegates to provide the country with strong institutions compared to those in Burkina Faso and Senegal. In his 1993 article Elster mentions a Norwegian historian Jens Arup Seip who suggested that people never try to bind themselves when it comes to constitution-making, because politics is about binding others. This way of looking at constitution-making makes sense when one analyses the process used in my three case study countries. In Burkina Faso and Senegal it can be argued that because the government in power controlled the process, institutions were created to fit the sitting power or at least to provide enough room to maneuver. For instance, in Senegal, the president nominates all constitutional council members. In Burkina Faso, the president is empowered by the constitution to nominate six of them plus the president of the Supreme Court who is the president of the Constitutional Chamber. The three others members are nominated by the president of the National Assembly who is usually from the president's 
party. This is not the case in Benin. The main reason is that in Benin, the delegates representing the president and his party were only ten percent of the 488 members of the national conference (Widner, 2005). In Benin, the president only nominates three of the seven members of the Constitutional Court. The rest are nominated by the National Assembly. Furthermore, the president of the nation, is not involved in setting up the interior rules of the Court whose president is elected by its members. In Burkina Faso, the president of the Supreme Court is the president of the constitutional chamber, and he is nominated by the president of the country. Because there are ten members, the view of the president of the chamber prevails in any case where there is a split of five against five. In Burkina Faso, the majority required to impeach the president ( $80 \%$ of the National Assembly members $)^{35}$ is higher than what is needed to amend the country's constitution (75\%). In Benin, it is the other way around. It is harder to amend the constitution (80\% of the National Assembly members) in Benin than to impeach the president $(66 \%) .{ }^{36}$ In Senegal the percentage for impeaching the president or any member of the government is identical to the one needed for a constitutional amendment $(60 \%){ }^{37}$ The Beninese constitutional drafters because they had more leverage in deciding what type of institutions to create and how strong they wanted them to be, offered their citizens constitutional rights to control government's actions. Unlike any constitutional court in the world, the Beninese court is directly accessible to any citizens or individuals living in the country. ${ }^{38}$ For instance, when on April 4, 1996, President Kérékou omitted a phrase of his presidential oath, a citizen reached out to the Court to get the president to retake his

\footnotetext{
${ }^{35}$ Article 139 of Burkina Faso Constitution

${ }^{36}$ Article 137 of Benin Constitution

${ }^{37}$ Article 101 and 103 of the Senegalese 2001 Constitution

${ }^{38}$ Articles 3 and 122 and 39 of the Beninese Constitution. Details on these articles are given in chapter VI.
} 
oath. ${ }^{39}$ The point is that the striking differences between the outcomes of the processes that led to constitutional adoptions in my three case study is explained by the process itself. In countries where the process was controlled, the outcomes happened to be more favorable to the sitting government in contrast to countries where the process was more transparent and open. Moreover, openness and transparency helped the framers in Benin to create stronger institutions by including in the constitutional document provisions known to provide balance and separation of powers, all things recommended by the literature on constitution-making. ${ }^{40}$ For instance, it is not advised that any president be given the right to nominate all constitutional court members because doing so weakens the court, particularly in countries with presidential supremacy (Fall, 2008).

${ }^{39}$ Details on this incident are given in chapter VI.

${ }^{40} \mathrm{I}$ am referring to the literature review done in chapters V and VI 


\section{Chapter V: Mechanism of constitutional amendment Introduction}

In this chapter, I am looking at the mechanism of constitutional amendments used in each country included in my study. My assumptions are that a rigid constitution will lead to fewer undue or non-consolidating changes in the initial constitutional document. In other words, constitutions with strong procedural constraints or numerous veto players for amendments would experience fewer politically motivated amendments. Actually, the stability of constitutional regimes and their performance (the ability to deliver wellbeing to people living under them), are often perceived as consequences of constitutional rigidity (Korenica \& Doli, 2011). In other words, the more rigid a constitution is, the more likely it is to provide regime stability that is needed for a people wellbeing. As such, constitutional rigidity is a counter-balance for politically motivated amendments of constitutional documents. The question then becomes what constitutes a rigid constitution?

To discuss this question of rigidity, I examine three indicators I consider essential: the different steps required for any constitutional amendment; referendums and petitions (table 16 shows the amendment strategy used by each country). The point that I am making is that the more steps are required for any single constitutional amendment, the harder it would be to make changes to a constitution. My reasoning is that the more difficult an amendment process is made, the less likely politicians would try to manipulate it to their advantage. The argument about the referendum is its notion of popular participation (a direct form of democracy) that carries great legitimacy. As such, 
the referendum can be a serious constraint on politicians who intend to use constitutional amendments to their advantage, particularly if a referendum is required by their constitution for any amendment. Referendums are financially and politically costly. Popular petitions can also serve as constraints to slow down any process of constitutional amendment as it is a form of direct democracy that allows citizens to check their public officials.

\section{Rigidity of constitutional amendment process}

A rigid constitution can be defined as a constitution that is difficult to amend (Loada \& Ibriga, 2007, p. 99). A constitution is considered formally rigid to the extent that it can only be amended through political procedures more complex than those used for ordinary legislations (Ferreres-Comella, 2000). Constitutions that used ordinary legislative process for amendments are labeled flexible constitutions (Viscount, 1901). Constitutions can be more or less rigid depending on certain factors and constitutional adoptions techniques mentioned in chapter two. One factor that can qualify a constitution as rigid is the number of political institutions that are required to participate in any amendment process. In federal system such as in the United States of America, there are several institutions that are required to take part in the constitutional amendment process. For the United States Constitution to be amended, it is necessary to obtain the consent of the federal Congress (or a Convention that is called by Congress on the application of the legislatures of two-thirds of the States). Beside the federal Congress's consent, it is also necessary to have the consent of the legislatures (or conventions) of three-fourths of the States. To these requirements, one needs to add the supermajority or qualified majority requirement that relates to the numbers of legislators or congressmen needed to adopt an 
amendment. A supermajority is always greater than the simple majority of fifty percent of a given legislature. Considering all the requirements or veto players (Tsebelis, 2002) needed for any amendment in the federal system, one can safely argue that federal constitutions are per se more difficult to revise than unitary states constitutions (Korenica \& Doli, 2011).

Actually, some of the requirements needed for any constitutional amendment in a federal system are also used in the unitary state system. This is the case for the supermajority requirement that exists in all three cases I consider in my study. In Benin ${ }^{41}$ that supermajority requirement is $4 / 5$ or $80 \%$ of the members of the National Assembly. In Burkina Faso ${ }^{42}$, it is $3 / 4$ or $75 \%$ of the members of the National Assembly, and in Senegal ${ }^{43}$ it is $3 / 5$ or $60 \%$ of the members of the National Assembly. As a reminder, my goal in this chapter is to take a close look at the initial constitutional documents of the three countries included in my work, to see what feature these documents have designed to protect the 'law of the land' from politically motivated modifications. My assumptions are that the trickier an amendment process, the greater chances a constitution is given to avoid non-consolidating amendments. The description of federalism allows me to address some features that are conventionally used to make constitutions rigid. Among those features is the supermajority requirement that is also used in unitary states such as Benin, Burkina Faso or Senegal. Besides the feature of supermajority requirement, constitutional framers in these countries have also thought of the number of steps necessary for an amendment as an additional obstacle or difficulty to the process. I am particularly

\footnotetext{
${ }^{41}$ Article 155 of the 1990 Benin Constitution

${ }^{42}$ Article 164 of the 1991 Burkina Faso Constitution

${ }^{43}$ Article 103, clause 5 of the 2002 Senegalese Constitution
} 
interested in this feature, as more steps mean more obstacles for any amendment success, that is, the greater the number of steps for a single amendment, the more rigid a constitution would be.

In Benin, the amendment process is made of two steps. For each step, there is a peculiar supermajority requirement. In the first step, the amendment project ${ }^{44}$ or proposition needs to be worthy of consideration by the National Assembly. It needs to be taken into consideration ${ }^{45}$. The supermajority as a feature of constitutional amendment is applied in Benin when dealing with a constitutional revision and also for organic laws. It is not applied for ordinary laws that only need a simple majority ${ }^{46}$. The second step that is described in Article 155 states that amendments are approved through referendum. However, a referendum may not be needed if the project or proposition of revision is approved by $4 / 5$ or $80 \%$ of the National Assembly members.

In Burkina Faso as in Benin, the amendment process happens in two similar steps. The first step happens through a vote on the principle of the amendment itself. The National Assembly decides whether to accept to take a look at a draft or proposal or to reject it. At this step absolute majority is required ${ }^{47}$. The second step consists in voting on

\footnotetext{
${ }^{44}$ When a constitutional amendment initiative comes from the president of the country, it is called a draft of revision. When it comes from the National Assembly, it is called a proposal of revision.

${ }^{45}$ The first step of the amendment process resembles the Rule of Four in the US Supreme Court. According to this rule, four of the nine justices must agree to hear a case in order for it to be accepted on appeal. If at least four justices believe a case is worth the Court's attention, a writ of certiorari is issued ordering a lower court to send to the Supreme Court the case files to be placed on the docket (Epstein \& Jack, 1998). In Benin, it is the rule that $3 / 4$ or $75 \%$ of the members of the National Assembly needed to agree to take into consideration any initiative of constitutional amendment.

${ }^{46}$ Article 105 of the December 1990 Benin constitution deals with ordinary laws while Article 154 states the first step of the constitutional amendment process.

${ }^{47}$ Absolute majority is used here in contrast with simple majority (a majority of those voting). In this particular context, it refers to the majority of all electors, not just those who participate in the vote, but also those who do not participate due to their not being there at the time of the vote or just because they opted for abstention.

It is important to mention that Article 163 of the June 1991 Burkina Faso constitution is vague on the issue of the required majority for the first step of the amendment process. It only states that a project or
} 
the modifying text. This vote can be done through a referendum. However, for any reason, the president of the country can choose not to use the referendum path. He can decide to submit any constitutional amendment directly to the National Assembly and that amendment is deemed successfully passed if approved by $3 / 4$ of the members ${ }^{48}$.

The amendment procedure chosen by Senegal, even though it follows a two-step process seems a little different from those used in Benin and Burkina Faso as it is not quite so binding. In the first step, the amendment is adopted in the same way as an ordinary law (by a simple majority). In the next step, an amendment is adopted by the National Assembly by a low majority ${ }^{49}$ of $3 / 5$ or $60 \%$ if the president chooses not to use the referendum. Now that we know what steps are needed in each country for a successful constitutional amendment, the question becomes, what makes one country's system better in preventing non-consolidating amendments than the other? In other words, what is the explanatory power of constitutional rigidity as a protective feature against undue or politically motivated amendment of the constitution?

My initial assumption was that the number of steps designed by constitutional framers in each of the three countries would set them apart when it comes to the ability of each document to defend itself against undue modifications of the original constitutional documents. Obviously, this is not the case when reading Articles 154 \& 155 (Benin), Articles $163 \& 164$ (Burkina Faso), and Article 103 (Senegal). Actually, all three

proposition of amendment should be submitted to the National Assembly after the review by the Chamber of Representatives. That is so, because from the beginning a broad and vague article namely Article 162: "La loi fixe les conditions et la mise en oeuvre de la procedure de revision," states that the law determines the conditions of the amendment process. This article because of its imprecision and vagueness was used in 1997 to create some non-consolidating amendments to the constitution (Garané, 1997). The idea of an absolute majority vote to accept or reject a proposition is not clearly stated in the initial constitution, but it came up in the January 23, 1997 constitutional amendment.

${ }^{48}$ Article 164 of the initial constitution of 1991.

${ }^{49}$ Fall (2011,.p.45) 
countries have the same number of steps required for any constitutional amendment: two steps. The first one consists of the National Assembly's accepting to put any proposed modification on the floor, the second one is the stage of decision on the particular issue. Should I infer from this observation that the number of steps required for a constitutional amendment does not matter as a tool designed to protect against undue amendment? The literature shows that the number of steps does matter (Lutz, 1994; Tsebelis, 2002;

Korenica \& Doli, 2011; Viscount, 1901). In this particular case study though, the number of steps for the amendment process does not help me make any significant comparative argument, as it is the same number for the three countries. What sets the countries apart is the required majority.

The qualified majority for each of the steps for amendment does matter. In Benin, $75 \%$ of the National Assembly is required to consider an amendment. In Burkina Faso that first step requirement is done at the absolute majority; in Senegal it is done at the simple majority. Looking at the number of non-consolidating amendments in each country, the qualified majority is a factor that deserves attention. In previous chapters, I mentioned that there has not been any non-consolidating amendment in Benin since the adoption of its constitution in 1990. There have been fewer non-consolidating amendments in Burkina Faso compared to Senegal. From zero undue amendments in Benin to fewer amendments in Burkina and amendments every seven months or so in Senegal, the observation is that in the country with the highest qualified majority requirement, we see no occurrence of any non-consolidating amendment. In Burkina Faso where absolute majority is the required majority, there are fewer amendments (only six) since the adoption of the constitution in 1991. As we know an absolute majority is a 
higher majority compared to the simple majority that is used in the case of Senegal where there are more amendments than any of the three countries under consideration. The conclusion here is that there is a link between the required majority and the number of constitutional amendments. Where the requirement is higher, there are no or fewer amendments compared to where the requirement is lower as in Senegal (Loada, Fall, \& Badet, 2008). I argue from the observation above that reformists or politicians supporting non-consolidating amendments are discouraged by the extent of the requirement or the difficulty of the process, since a comparative look at the three countries shows that as the required majority for constitutional amendments goes up, the number of nonconsolidating amendments decreases. Does my analysis show that there has been no amendment in Benin because of the country's choice for a higher required majority? The answer to this question might not be as simple as it looks since the required majority is not the only factor that counts when analyzing the reason for non-consolidating amendment occurrence. However, it is safe to say based on constitutional literature (Lutz, 1994; Loada, Badet \& Fall, 2008; Tsebelis, 2002; Viscount, 1901) that the harder a constitutional amendment process is, the better chances the constitution has to be protected against politically motivated amendments.

My analysis shows that there are more obstacles designed by Benin's constitutional framers than those in Burkina Faso or in Senegal. My study also shows that the Burkinabe framers engineered a harder to amendment constitution than the Senegalese framers, the absolute majority required by the Burkinabe framers being more difficult to obtain than the simple majority vote needed in Senegal for a constitutional amendment. In conclusion, there is not much difference among Benin, Burkina Faso and 
Senegal when it comes to the number of steps for constitutional amendment. The differences emerge as a function of the qualified majority designed by each country's framers to protect the constitution against undue amendments. My comparative study of the three countries confirmed what other scholars (Loada, Badet \& Fall., 2008; Fall, 2011) have suggested. As the qualified majority increases, the number of constitutional amendments decreases (80\% qualified majority in Benin with zero amendment; 75\% in Burkina Faso with one amendment and 60\% in Senegal with eleven amendments). Consequently, the Beninese Constitution is made safer against non-consolidating amendments than the other two countries' constitution. However, qualified majority is not the only factor that is known as a safeguard against undue amends. A referendum can also play a similar role depending on how it is handled.

\section{Referendum as a constitutional safeguard}

A referendum is a direct vote that offers an opportunity for an entire electorate to either accept or reject a particular proposal. It is a mechanism designed to produce a popular and unfiltered opinion on a given important issue. I am using the word "unfiltered" to emphasize the difference between a referendum vote and a vote made by representatives of the people through a legislative body, as a referendum vote is direct. In representative democracy, votes made through a National Assembly are indirect votes since legislators are representatives of the people in the name of whom they vote. According to Suksi (1993), democracy is direct only to the extent that citizens themselves initiate issues for discussion and vote on them. ${ }^{50}$. In other words, in representative

\footnotetext{
${ }^{50}$ From this particular understanding of what direct democracy is, a person elected by the people to vote and decide on their behalf is a delegate if he acts strictly according to the instructions of his constituency. A
} 
democracy citizens are not given the opportunity to decide as often as might be expected. To remedy this lack of public direct participation in politics Dicey (1894) suggests referendums as an alternative to other democratic checks on politicians. The author sees referendums as a popular safeguard against encroachments by elected politicians. Arguing for the adoption of referendum in England, Dicey (1890) explains that referendum without being a substitute for a representative form of government strengthens it. For him, elected representatives would pay closer attention to citizens' concerns if the fate of any controversial law ultimately depended on referendums. The idea is that constitutional issues should be given obligatory referendums. Actually, this is what I am arguing in this particular section of my study.

I suggest that initial constitutions in the countries I study can be designed in such way that there are safeguards against undue amendments. One of these safeguards I am referring to is the referendum. The idea is that from the initial constitutional document it can be made absolutely clear what issues must be decided through referendums and only through referendums. Actually, it is the raison d'être of the referendum that it should be a constitutional safeguard (Qvortrup, 2002). As the author explains, however, there is no guarantee that referendums will always provide citizens with the check they expect on parliaments, because the initiative for referendums is often left to politicians. Politicians mainly use referendums to reinforce their legitimacy and empower themselves on given issues (Morel, 2007). The author calls this particular use of the referendum powerreinforcing, because the initiator uses the referendum for a personal purpose. He can also

politician is called a representative to the extent that he is free to decide how he votes on the behalf of his constituency (Institut Africain pour la Démocratie, 1997, p. 18). In the three countries included in my study, National Assembly members are representatives as defined above. 
use it to weaken opponents as did the minority government of President de Gaulle in 1958 to obtain a popular legitimation of his presidency that was going through some tough times. In 2000, the Chirac government requested a referendum on the reduction of the presidential mandate from 7 to 5 years. Although a point can be made that it was somewhat forced upon him (Morel, 2007), the request was used to reassert President Chirac's preeminence over his socialist Prime Minister. By presenting himself as the initiator of the referendum, he showed himself as a leader who was so concerned about democratic values that he allowed the French people to decide on the length of his own mandate. The French government's use of referendums is what Morel (2007) calls plebiscite. The term plebiscite also refers to the ad hoc (unplanned) nature of a referendum that can be a vote of confidence about a government's policies (Suksi, 1993). The timing of such a vote is not dictated by the constitution, but is based on political calculations. According to Lijphart (1984, p.221), politicians will only use referendums when they expect to win. Butler and Ranney (1978) have similar views. They suggest that referendums are used infrequently by governments usually when politicians expect them to help provide a useful ad hoc solution to a pressing issue.

As we can see, there is no consensus in the literature on how effectively a referendum can serve as a "people veto" in a way Dicey (1890) would prefer to see referendums being used. Whenever referendums are used on the initiative of political leaders, they are likely to deviate from their original mission, which is to allow ordinary citizens to check their representatives. For political reasons government officials will allow referendums only when they are sure to come out safe from a referendum vote. In such conditions, referendums can only benefit leaders since they are used as an elite 
strengthening device (Santori, 1989, p.130). Actually, it is widely accepted in the literature that obligatory referendums (those not controlled by governments) and also popular initiatives are less politicized and consequently produce higher democratic quality than plebiscites and other types of governments-initiated referendums (Papadopoulos 199551; Qvortrup 2002: Lijphart 1984; Morel 2007). The argument comes down to the notion of referendum control. Whoever controls a referendum determines how efficiently and effectively that referendum will fulfill its mission of checking elected representatives.

Butler and Ranney (1978) argue that since the mid-1970s, experience has shown that referendums are held primarily at the initiative of elected officials. Only a few referendums were held as obligatory or compulsory referendums mainly for constitutional amendments. Qvortrup (2002) tests this assertion using Gordon Smith's typology of referendums. Smith (1976) divides all referendums into two categories: the controlled and the uncontrolled referendums. Uncontrolled or obligatory referendums are those initiated by opposition parties and by citizens. Referendums initiated by governments and elected officials are considered controlled. Given that the results of a referendum can be either favorable or unfavorable to a government, Smith distinguishes between two sub-categories: the pro-hegemonic and the anti-hegemonic referendums. Pro-hegemonic referendums are those supportive of elected officials. The anti-hegemonic are those referendums that are unfavorable to governments and that can potentially be politically damaging to elected officials who campaigned against them. In contrast to Lijphart (1984) assumptions that most referendums are not only government-controlled,

\footnotetext{
${ }^{51}$ This article was cited in Morel 2007 p.1044
} 
but also pro-hegemonic, Qvortrup (2002) argues that most referendums (104 out of the 128 included in his study) are uncontrolled. The author agrees however, that there is enough support for the assertion that governments submit issues to referendums only when they expect politically favorable outcomes for themselves.

Thus a study of the general concept of referendums shows that they are an important constitutional feature that can be used against undue revisions of constitutions. As a tool of direct democracy, referendums are a supplement, not a substitute to representative democracy. Referendums can be viewed as a people's veto against their representatives' tendency to abuse their mandate. Furthermore, there seems to be a consensus among specialists that referendums strengthen representative democracy and the rule of law when used appropriately. This confirms my initial assumption that referendums as a constitutional feature can be used effectively to prevent nonconsolidating constitutional amendments. How effectively and efficiently can they protect against undue amendments? The answer to this question according to the literature is that everything depends on how referendums are used. In the Westerns world, researchers seem concerned about why politicians use referendum and which type of referendum use is more efficient (Morel, 2007). In the cases I am studying, the big concern is rather why politicians don't often use referendums. Before further analysis of this phenomenon of avoidance of referendums by West African elected officials, let's take a look at the provisions on constitutional referendums in the three countries.

Article 154 of the Republic of Benin's Constitution states that the initiative of constitutional amendment belongs to the President and the members of the National Assembly. However, for any project or proposition of amendment to be taken into 
consideration, it must have the approval of $3 / 4$ of the national members. Article 155 of the same constitution clarifies that an amendment only becomes law when it is finally approved through referendum or when it is voted for by $4 / 5$ of the National Assembly members. In Benin, the concept of referendum is addressed in title XI that deals with constitutional amendments. In Burkina Faso, this matter is addressed in title XV. Article 161 states that constitutional amendment initiative belongs to the President, to the members of the National Assembly and to the people once at least thirty thousands of people in voting age introduce a written and signed petition to the National Assembly. Article 163 clarifies that any amendment project must go through the National Assembly first $^{52}$. Article 164 of the Burkinabe constitution states that a constitutional amendment is deemed adopted through referendum once it obtained the majority of the popular votes. However, an amendment can also be adopted without referendum once it is approved by 3/4 of the National Assembly. In Senegal, Article 103, the single article in title XII that deals with the amendment process, states in its first clause that the initiative of constitutional amendment belongs to the President and the National Assembly members. As in Benin and Burkina Faso the Senegalese constitutional requires that any amendment go through the National Assembly first. In the third clause of Article 103 it is stated than amendments are adopted through referendums. However, as in the other two countries, there is a provision in the Senegalese constitution that helps avoid referendums since it allows the president to directly submit any amendment to the National Assembly if he

\footnotetext{
${ }^{52}$ It is important to mention that this particular constitutional provision informs us that any amendment project, no matter where it comes from, needs to be approved by the National Assembly first. That is what Suksi (1993 p.9) refers to as indirect initiative. In the case of Burkina Faso, any petition submitted to the National Assembly would qualify as an indirect initiative. An initiative is considered indirect to the extent that it must go through a representative body that could deliberate on it or modify it before it is put to a referendum vote. A direct initiative does not go through such a process.
} 
chooses to do so. In such a case the amendment is deemed adopted if approved by $3 / 5$ of its members.

It is worth mentioning that in the three cases included in my study I am first and above all dealing with constitutional referendums. The description of each country's provision on referendum shows that these features are only mentioned in relation to constitutional amendment. Actually, in these countries the only time referendums are used is when new constitutions are being adopted. Otherwise, amendments to constitutions are primarily done through the legislative body, since provisions in initial constitutional documents allow politicians to do so. In Benin it is Article 155 that does the trick; in Burkina Faso, it is Article 164 that allows the president to adopt any amendment to the constitution without using the path of the referendum; and in Senegal it the third clause of Article 103 that allows the president to avoid referendums. Even though the literature shows that a referendum carries a greater advantage of legitimacy compared to legislatives votes (Adams 1980; Morgan 1988), Francophone West Africans leaders prefer to adopt constitutional amendments through national assemblies. Of the six amendments done in Burkina Faso since 1991 and of the many others done in Senegal since 2001, not a single one was done through a referendum. In contrast with the Western world where referendums are used by government officials to their advantage Morel, 2007), in West Africa, government officials are avoiding referendums to their advantage.

One can make the point that referendums are costly; therefore it makes sense for poor and developing countries to avoid them. When looking closely at the phenomenon of referendum avoidance in the countries I study, however, one will certainly realize that there are other hidden reasons behind it. It is noteworthy to understand that in Burkina 
Faso and Senegal the provision allowing presidents to get constitutional amendments approved by parliament instead of by referendum is included in the constitutions as optional. The primary path for adoption of amendments to the constitution is referendum. In other words, adoption through referendums is the regular or normal way and adoption through parliaments is a secondary or exceptional way of getting to the same results of amending constitutions. In a weird move, West African presidents prefer to use the secondary or exceptional path instead of using the normal way (referendum) to amend constitutions. Parliamentarian adoption is now the normal path while referendum becomes secondary or exceptional way of adopting amendments. This is not the initial intention of the framers (Fall, 2011). Actually, the systematic use of a subsidiary way for amendments is a fraud to the constitution as suggested in Kanté's work (Cited in Fall, 2011). In the two countries where there have been some non-consolidating amendments, the party in power always has the required majority in the National Assembly to make any modification to the constitution. When using the legislative path, the government in power does not need to face the popular vote. Due to party discipline ${ }^{53}$ in these countries it is easier for a government whose party is in control of the parliament to use the path of the National Assembly for amendments, particularly when these amendments are contentious and might attract international observers' attention. African leaders might also prefer to avoid referendums as an unsuccessful referendum can be of great political damage to a government.

\footnotetext{
${ }^{53}$ I am using the expression of party discipline to refers to the often unwritten or 'invisible party rules' that make the allegiance to a party obligatory. Elected representatives usually vote in the line of their party. This is particularly true in Francophone Africa where the president is known to be the one running the show even in semi-presidential countries like Burkina Faso and Senegal, Benin having chosen for a presidential system (Fall, Le pouvoir Exécutif dans le Constitutionalisme des Etats d'Afrique, 2008)
} 
The question now is to know how the description of the referendum provision in the constitutions I am studying helps my argument. As a reminder, my intention in this particular section is to show that the avoidance of referendums as a people veto against their representatives' misuse of their mandate facilitates the emergence of nonconsolidating constitutional amendments. Literature has shown that referendums can be good remedy against undue amendments of constitutions. Moreover, referendums are used efficiently when uncontrolled by government officials. However, my analysis of the three African countries reveals that referendums are almost never used. In fact, leaders do not have to use them since there is a constitutional provision that allows politicians to do away from referendums. Whenever referendums are used, it is always through the initiative of politicians. Politicians have a monopoly on the initiative of referendums and they usually don't call for referendums unless they are convinced it will work out to their advantage. Consequently, constitutional referendum votes have happened only once in each of the countries studied and that was during the adoption of new constitutions. Adoption of new constitutions cannot be considered as uncontrolled referendums (Qvortrup, 2002). After all, governments in power during the adoption period usually decide when the referendum takes place. The other issue to be raised is that in Burkina Faso for instance, the military government in place at the time of the new constitution adoption not only initiated the referendum, but also decided who would take part at the drafting stage the government giving directives about what could be included or not in the new constitution (Ye, 1995).

Let's make it clear, my point in discussing the avoidance of referendums is not to claim that the use of constitutional provisions to circumvent referendums is 
unconstitutional. What I am suggesting is that in the context of West African politics where the government in power usually has well beyond the required majority at the National Assembly, and can therefore modify the constitution any time it sees fit, making constitutional amendments through legislatures and only through legislatures facilitates the occurrences of non-consolidating amendments. Had referendums being used and used properly to fulfill their original mission (discussed above), it would have helped considerably in curbing the great number of undue constitutional amendments in Burkina Faso and Senegal. One can argue that the use of referendums would not have made any difference against non-consolidating amendments. In other words, with the same kind of constitutional provision (Article 155 in Benin, Article 164 in Burkina Faso, and Article 103 in Senegal) in the three countries, why has Benin not had any successful amendments since 1990 while Burkina Faso had at least five and Senegal has many more amendments?

My response to this question would be that the possibility of referendums as a constitutional device all by itself is not enough to prevent all types of non-consolidating amendments. Therefore it cannot be the only variable to account for any single amendment. Along with other factors it contributes in preventing non-consolidating amendments. Along with other factors it helps explain the failure to prevent undue amendments. When analyzing the nature of referendums one can understand that if properly used the device can be effective against constitutional frauds. In the countries I study, referendums have not been used enough for me to make any useful comparisons between countries, but based on the studies done by authors (Qvortrup 2002; Dicey 1890; Lijphart 1984; Morel 2007) it appears that referendums are valuable tools when used 
appropriately. The fact that they are not used very often in the countries included in my study does not make this particular section unimportant. It only makes the comparison between countries shorter, since there are more similarities than differences. It does not mean that referendum is not a good explanatory variable when it comes to curbing nonconsolidating amendments in the particular countries chosen. Actually, the avoidance of referendums facilitates the occurrence of non-consolidating amendments. In other words, non-consolidating amendments can be prevented through a regular and proper use of referendums. No study shows that referendums if used in the West African cases would not have helped against undue modifications. In contrast, literature shows that referendums are useful constitutional features designed to give the people a say in public affairs and to prevent elected officials from overusing their public mandate. The same philosophy of giving citizens a say in the conduct of public affairs is behind the introduction of public petition as an important tool in the hands of people. How useful is this other constitutional device? This is a question I will try to answer in the next section.

\section{Public right to petition}

Petition as it exists in the 1991 Burkina Faso constitution ${ }^{54}$ can be defined as an initiative. An initiative is known in the US as a request signed by a number of registered voters to get public officials to consider a particular issue: a constitutional amendment, an ordinance or a statute or any other issue (Suksi, 1993). There are two types of initiatives: direct and indirect initiative. Under a direct initiative, a petition is put to a vote once it

\footnotetext{
${ }^{54}$ Article 161. Also, Burkina Faso is the only country among the three countries included in my study to have a constitutional provision giving citizens the right to constitutional amendment.
} 
satisfies the required number of signatures. An indirect initiative has to be approved by a legislature before it is put to a vote. Initiative or public petition is considered a feature of direct democracy. "Men love power...Give all power to the many, they will oppress the few. Give all power to the few, they will oppress the many. Both therefore ought to have power, that each may defend itself against the other." Alexander Hamilton cited in Cronin (1989, p.7). A major debate about referendums and initiatives is whether it is desirable to give more power to the people in public affairs. In other words, is active participation of citizens in public business through diverse forms of direct democracy desirable? According to Cronin (1989) populists and progressives in America are calling for more direct democracy in order to achieve a more robust and healthier democracy in the US. The assumptions behind these calls are that the cure for the ills of representative democracy is more democracy, and more direct democracy in any forms: referendums, initiatives, and recalls.

For Cronin, Americans are torn between the desire of letting responsible and informed leaders make decisions for them and the idea that ordinary citizens should also be allowed to make decisions, since on important issues, the public can be trusted to do what is right just about as often as elected politicians can be trusted. In a survey with a sample of 1026, participants were asked whether they think that elected officials know more than ordinary citizens about issues and should be allowed to make whatever decisions they think best. Only 8 percent believe that elected officials know more that citizens and that they deserve to make whatever decision they think is best for the country. 68 percent think elected officials would misuse their power if they were not watched and guided by the voters (Cronin, 1989, p. 9). On the question about whether 
people with more knowledge and character should have greater influence over the country's decisions than other people, only 39\% answer yes, with $45 \%$ responding with a negative answer, because according to them every citizen must have an equal right to decide what is best for the country. From the few answers provided here, the tendency seems to be going for more direct democracy.

Actually, proponents of initiative argue that it would promote government responsiveness and accountability, because this particular feature of direct democracy offers the people the right to make laws. Initiatives and referendums are means for citizens to participate in public affairs. They can be used to fix unwanted laws made by elected representatives who are subject to corruption by special interests. The assumption is that it is harder and even impossible to corrupt an entire people of a country than to corrupt a few representatives of those people. One major argument made by proponents of direct democracy through initiative and referendum is that they increase voters' interest on public issues due to the publicity that always arise during these kind of events. Moreover, initiatives are necessary in a political world where officials always try to avoid tough questions for fear of losing their seats.

For proponents of direct democracy, because elected officials are representatives of the people, there should always be a mechanism that allows the people to have a direct say any time an issue is known to be of a great importance to the country. People come first. Governments are instituted to protect and improve the wellbeing of their citizens. This particular argument was known in colonial America as the doctrine of consent. Governments exist because people first consented to be governed. A representative government should not be so important as to deny the right to the people to express itself 
through direct democracy (Cronin, 1989). So goes the argument for the use of initiative referendum and recall. As strong as these arguments can be, there are also some compelling arguments against initiatives.

The first and most basic argument against direct democracy in all forms is that direct democracy isn't practical. A country cannot be governed through referendums, initiatives and recalls. Secondly, ordinary citizens do not have the necessary time to devote to a particular issue in order to have as much knowledge as professional politicians or elected officials. Moreover, initiatives and referendums do not allow the deliberation needed for decision-making on a complicated and serious issue such as a budget or a constitutional amendment that may require specialized knowledge on a very particular issue. Cronin (1989) analyzes both arguments for and against direct democratic practices such as referendums, initiatives and recalls in the American context. He concludes his chapter on ordinary voters' knowledge with a very interesting question. Since critics of direct democracy see ordinary citizens as an uninformed and unworthy mob to be kept out of any serious decision-making process, Cronin asks "How is it that they can choose between good and bad candidates, but cannot choose between good and bad laws?" (Cronin, 1989, p. 87). Similar to Dicey (1890) position on referendum, Cronin seems to come to the conclusion after studying voters' competence in the US and interviewing legislators and political scientists that there is no evil in the use of such direct forms of democracy as initiatives, recalls and referendums. None of these authors advocate for a substitution of direct democracy for a representative form of democracy. Both authors acknowledge the usefulness of direct democracy as well as representative democracy with an emphasis on the fact that both forms of democracy as complementary. 
Actually, it does not seem desirable or even helpful to use any of these forms of government as a substitute for the other. The reasonable solution that comes from the literature review I just did on referendums and initiatives suggests that direct democracy should be given more attention in order not only to keep representation democracy going but, above all, to make it better serve its purpose of delivering wellbeing to the people. How does initiative works in the Francophone West African context, and how does it contribute to my argument about using constitutional features such as the initiative to protect against political revisions of the original constitutional document and how does it help the rule of law in democratizing countries?

Table 16: comparison of constitutional amendment strategy

\begin{tabular}{|l|l|l|l|}
\cline { 2 - 4 } \multicolumn{1}{c|}{} & $\begin{array}{l}\text { Constitutional } \\
\text { rigidity }\end{array}$ & Referendum & Public Petition \\
\hline Benin & Yes & Yes & No \\
\hline Burkina Faso & Yes & Yes & Yes \\
\hline Senegal & Yes & Yes & No \\
\hline
\end{tabular}

To begin, let's point out that initiative does not exist in Benin as a constitutional device allowing citizens to propose laws to the National Assembly, neither does it exist in Senegal. As mentioned above, constitutions in both countries state that only the president and the members of the National Assembly are allowed to submit laws for adoption. These countries' constitutions do not provide for any initiative or recall as known in the US. As a reminder, a recall is a procedural device that offers voting age citizens the right to discharge and replace a public official. An initiative, a close relative of the referendum 
according to Qvortrup (2002, p.58) enables citizens to propose constitutional amendments. As such, it is called a constitutional initiative. When it allows people to propose laws, it is called a direct legislative initiative. It is called an indirect legislative initiative when it only enables citizens to propose laws that will need to be debated or modified by members of parliaments before any adoption. Article 161 of the Burkina Faso constitution provides the people with for a constitutional initiative. Besides the President and the members of the National Assembly, voters in Burkina Faso can submit constitutional amendments to the National Assembly. However, no proposed amendment is voted on unless the National Assembly decides to do so. Initiative as it exists in Burkina Faso is therefore an indirect constitutional initiative according to the terms of Article 163 that states that any project or proposition of amendment is first submitted to the approval of the National Assembly members.

The Benin Constitution does not provide for any initiative or recall. However, it offers a great opportunity to the people of Benin that is worth mentioning. Article 122 provides citizens of Benin with the ability to oversee the constitutionality of the country's laws. Any person citizens or not who live in Benin (Adenauer, 2009; Salami, 2005 p.201; Tama, 2009 p.160) can access the Constitutional Court either directly or through another court in order to challenge the constitutionality of any given law. Such a provision does not exist in the other two countries I am studying. Actually, there are noticeable differences in the three constitutions. Only Burkina Faso has included the device of initiative in its constitution, although it has never been used since the constitution was adopted in 1991. To briefly summarize my findings on initiative in Benin, Burkina Faso and Senegal, let's put it this way: the Beninese Constitution through its Articles 3 and 
122 gives power to its citizens to check on the constitutionality of laws, such an opportunity does not exist in Burkina. It does not exist in Senegal either. Article 161 of the Burkinabe constitution provides for initiative. Citizens through a petition of at least thirty thousand signatures can submit a constitutional amendment to the National Assembly. This opportunity does not exist in the other two countries. Based on the literature in this section of my work initiative is an important constitutional device. Burkina Faso's having included this device in its constitution is a plus for the country.

Like the referendum, the initiative device has shown its virtues. My discussion on this particular issue made the point that initiatives are useful tools for direct democracy (Cronin 1989; Qvortrup 2002; Suksi 1993). This makes it a good concept to consider when studying safeguards to constitutional amendments. Since the literature shows the importance of initiative for a healthy democratic system, I argue that the lack of this tool in any democratizing country can be interpreted as a weakness in the constitutional document when it comes to providing citizens with what they need for a vigorous and strong democratic system. This assertion has some shortcomings when it comes to making a comparative argument such as: there is a reduced number of non-consolidating amendments in Burkina Faso compared to Senegal due to the use of initiative. One cannot make this kind of argument as there is no initiative in Senegal or in Benin and even in Burkina Faso where it exists it has not been used. Consequently, it becomes almost impossible to measure the effectiveness of initiatives in preserving one country's constitution against non-consolidating amendments compared to the other countries. The fact that I am not able to make a comparative argument does not weaken my main argument. It reinforces it! Remember, my initial assumption has been that the occurrence 
of non-consolidating amendments in the countries I am studying is being facilitated in part, by the absence of importance constitutional devices such as initiatives and referendums. The virtues of these features are known from their use in well-respected democracies such as in the US (Cronin, 1989; Qvortrup 2002; Suksi 1993). 
Table 17: Steps for constitutional amendment

\begin{tabular}{|l|l|l|l|l|l|}
\cline { 2 - 6 } \multicolumn{1}{c|}{} & $\begin{array}{l}\text { The initiative of } \\
\text { amendment belong } \\
\text { to: }\end{array}$ & $\begin{array}{l}\text { Two-step } \\
\text { Process of } \\
\text { amendment }\end{array}$ & $\begin{array}{l}\text { Step 1: Required } \\
\text { majority for considering } \\
\text { an amendment }\end{array}$ & $\begin{array}{l}\text { Step 2: Required } \\
\text { majority for adopting } \\
\text { an amendment }\end{array}$ & $\begin{array}{l}\text { Number of Non- } \\
\text { consolidating } \\
\text { amendments }\end{array}$ \\
\hline Benin & $\begin{array}{l}\text { - President } \\
-\quad \begin{array}{l}\text { National } \\
\text { Assembly } \\
\text { members }\end{array}\end{array}$ & Yes & $75 \%$ of MPs & $80 \%$ & 00 \\
\hline Burkina Faso & $\begin{array}{l}\text { President } \\
-\begin{array}{l}\text { Majority of the } \\
\text { National } \\
\text { Assembly } \\
\text { Thirty thousand } \\
\text { voting age } \\
\text { citizens }\end{array}\end{array}$ & Yes & Absolute majority & $75 \%$ & 03 \\
\hline Senegal & $\begin{array}{l}\text { President } \\
\text { National } \\
\text { Assembly }\end{array}$ & Yes & Simple majority & $60 \%$ & 10 \\
\hline
\end{tabular}




\section{Conclusion}

The objective in chapter $\mathrm{V}$ was to show that the procedure of amendment adopted in my case study countries would make a difference when it comes to preventing undue constitutional amendments. The country with stronger constraints on the process is expected to experience fewer non-consolidating amendments compared to the others. I examined three of such constraints: the number of steps for a constitutional amendment; referendums and petitions. For the number of steps required for any constitutional amendment, my comparative analysis shows that there exist two steps in each country. Although all three countries have the same number of steps required for amendments, there are important differences among them when it comes to the qualified majorities for each step. While in Benin 75\% approval of the National Assembly is required at the first step to move any proposal of amendment forward in Burkina Faso only an absolute majority is needed and in Senegal a simple majority does the trick. At the second step $80 \%$ of the National Assembly is required in Benin; $75 \%$ in Burkina Faso and $60 \%$ in Senegal. The interesting observation I made is that the number of amendments decreases as the required majority increases (see table 17 above). My conclusion is that although all three countries (Benin, Burkina Faso and Senegal) have the same number of steps required for any constitutional amendment, the single important factor that explains the difference among the number of their non-consolidating amendments is the required majority. Regarding the referendum, I noticed that all three countries only used referendums once and that single time was during the adoption of their initial constitutions. Since then, politicians are avoiding referendum as a path to constitutional 
amendment. According to Article 164 of the Burkina Faso Constitution and Article 103 of the Senegalese Constitution, referendum is the normal and first path for constitutional amendment. However, because referendums are financially costly and mainly because they can be politically damaging (for reasons mentioned above), they have never been used for constitutional amendments. I argue that the avoidance of referendums by politicians has contributed to their successful experiences of non-consolidating amendments. I make similar claim about the absence of public petition as a provision in the Senegalese Constitution. In Burkina Faso, the provision exists, but it has never been used. Even if it were to be used, there is another provision (Article 163) that allows the National Assembly to block any popular initiative. Consequently, public petition can be considered as a window dressing provision in the Burkinabe Constitution. 


\section{Chapter VI: Independence of the Constitutional Court Introduction}

My general goal in chapter VI is to show, that Constitutional courts can play an important institutional role in protecting a constitution against undue amendments. For a court to efficiently fulfill such a mission, however, it must be given real powers, preferably constitutional powers. Simply put, a Constitutional court needs to be independent. My assumption is that the more independent a court is the more effective and efficient it would be in preventing politically motivated amendments to the constitution. The question is how independent should a constitutional court be? Can a court ever be independent and how do we know a court is independent? I measure the independence of constitutional courts using three indicators: the appointment of constitutional court judges, their term in office and the way they are removed from office. The reasoning behind the choice of these indicators derives mainly from concerns about transparency, and the balance and separation of powers. In this study, for instance, a court is not considered independent when all his members are nominated by a single government official. What is in jeopardy in such a situation is the fundamental democratic principle of the separation and balance of powers. This same principle is also in jeopardy when politicians are given the authority to control judges' salaries or their removal from office. In this chapter, I comparatively examine constitutional powers given to my three case study constitutional courts. I look at the relationships of the courts with the other government branches. I also take a look at the courts' internal rules of decision-making to see whether the court is controlled from outside. For example, a provision in Burkina Faso states that if in deciding a case the court is split five against 
five, the opinion of the court's president prevails. ${ }^{55}$.Such a provision regulating the internal functioning of the court can be a serious obstacle to the court's independence, since the president of the court is nominated by the president of Burkina Faso. I conclude the chapter by acknowledging that a constitutional court can be a strong safeguard against undue constitutional amendments as long as it is given real constitutional powers like those of the Beninese Court. I also hold for true, based on my comparative analysis, that the constitutional courts in Burkina Faso and Senegal are less effective due to the weak constitutional powers given to them by their initial constitutions (see table 18 below for a succinct summary). To this weakness is added the control by the executive power and the lack of courage on the part of the constitutional courts to take on politicians in these countries (C.G.D, 2009).

\section{Selection of Judges to the Court}

Article X of the Universal Declaration of Human Rights states that an independent Judiciary is a fundamental human right. Much of the literature on judicial independence fails to clearly say what constitutes judicial independence even though there is a consensus on how valuable it is (Cross, 2008). According to the author, judicial independence is more a matter of degree. It should not be understood in the sense of a binary determination of dependent or independent. Broadly speaking, independence can be defined as the freedom to act with no constraints. If the judiciary is to be independent, from whom or from what should it be independent? Assuming that the judiciary is one branch of an entire body namely the government, the answer to this question might be

\footnotetext{
${ }^{55}$ Details on this provisions are given later in the text
} 
that the judiciary needs to be independent from the other branches of government: the executive and the legislative.

How can the judiciary be independent from other institutions with which it constitutes one unique body: the government? Put differently, can one think of a judiciary that exists with no executive or legislative branches of the government? Actually, judicial independence does not mean that the judiciary should be completely isolated from the other parts of the government. An absolute independence is certainly unrealistic (Russell, 2001, pp. 11-12). The judiciary is like a referee, a neutral referee with the mission of presiding over the game of governing. Judicial independence is more about the courts' freedom from control by others governmental institutions and from any outside pressure. It is better understood when thought of as a notion of conflict resolution by a neutral third party, a third party that can be trusted to impartially settle controversies (Shapiro, 1981). The rational for judicial independence is to be found in the theory of separation of powers. In the Federalist, Hamilton (cited in Panizza, 2001) argues that "there is no liberty, if the power of judging be not separated from the legislature and the executive powers." Quantitative evidence exists to assert that the separation of power actually reduces governmental corruption (Panizza, 2001).

The typical approach to securing judicial independence is through constitutional provisions, such as life tenure and guarantee for judges' salaries (Cross, 2008; Keith, 2002). Constitutional protections alone, however, are not always enough for judicial independence. For instance, in the former Soviet Union, despite the existence of a constitution, a phenomenon known as "telephone justice" was a recurrent practice of authorities that consisted of calling judges to tell them how they should vote on a 
particular case. In contrast with this example, Russell (2001, p. 22) talks about the United Kingdom where judicial independence is fairly preserved even with no written constitutional protections for judges. As a strong advocate for political insularity ${ }^{56}$ of the judiciary (Fiss, 1993) acknowledged that constitutionalizing judicial independence is an important step toward reaching judicial independence. The author cites Article III, Section 1 of the US Constitution that offers life tenure and protection against diminution of pay as a guarantee of judicial independence. Some researchers argue that once politics is involved in the selection of judges, no matter the level of transparency, judicial independence is compromised (Peretti, 2002). Actually, the judiciary is both a legal institution and a political one. As such, judicial independence cannot be perfect per se.

Article II, section 2, clause 2 of the US Constitution gives the president the power to appoint the US Supreme Court Justices. Presidents usually delegate the initial phase of the selection to their attorney general, their chief of staff or other top advisers and many things happen behind the scenes (Segal, Spaeth, \& Benesh, 2005). Presidents receive recommendations from interest groups or politicians and filter them. Once a name is retained, it is passed to the Federal Bureau of Investigation (FBI) for investigation before the nominee is announced by the president. Because of the crucial role played by the US Supreme Court as a policy-maker, presidents usually pay close attention to the ideology and partisanship of potential nominees. A president is more likely to choose someone whose vision of justice approximates his own, someone who is likely to support his administration's policies (Fiss, 1993). Segal Spaeth and Benesh in their 2005 study found that (87 percent) of nominees have been member of the president's party. President

\footnotetext{
${ }^{56}$ Fiss (1993) uses the term political insularity to refer to the independence of the judiciary from all political institutions and also from public in general.
} 
Reagan is known for his 1990 campaign platform that clearly favored nomination of justices who "were harsh on crime, opposed abortion, and favored school prayer" Segal Spaeth and Benesh (2005, p. 249). The same study argues that about $3 / 5$ of those nominated at the US Supreme Court personally knew the president who appointed them. "The most important appointments a President makes are those to the Supreme Court of the United States" (Richard Nixon cited in Segal Spaeth and Benesh 2005, p. 247). It can be interpreted from this statement that judicial appointments are highly political, since the president has every interest of having a judge that would support his view on the Court, especially when the president is no longer in office, provided that the US Supreme Court Justices are nominated for life. After a president has made his choice of a nominee for the US Supreme Court, the next step is the Senate confirmation. Of the 147 nominees considered in Segal, Spaeth, and Benesh (2005) 120 or 82 percent have been confirmed.

There are significant differences between the US justices' appointment process and the one used in Benin, Burkina Faso, and Senegal countries with a civil law tradition. More importantly, in the US, we are dealing with a unique judicial system whereas my cases study countries use a particular type of institution called Constitutional council or Constitutional court. Constitutional courts are often more political than judicial institutions, but because most of them are empowered to oversee the constitutionality of laws, there are often viewed as having the power of the American Supreme Court, which is not true (Ferejohn, 2002, p. 49). Constitutional courts or constitutional councils are a particular type of institutions separated from the judiciary and with the unique mission of caring only about the constitution. They are courts of first and last resort. As the highest courts in their domain of competence they look like supreme courts, but unlike the US 
Supreme Court which can take on any given issue, constitutional courts are concerned with constitution only. These specialized courts adopted the Kelsenian ${ }^{57}$ model of judicial review (Beyme, 1988). The model differs from the decentralized American judicial review model that allows posteriori decisions. The Kelsenian model of constitutional court is centralized because there is a single court that decides on constitutionality, and it mainly has a priori decision powers. It decides on laws not yet promulgated. In the Kelsenian model, we are dealing with "constitutional review" not judicial review (Volcansek, 2007).

The historical context in which the Kelsenian constitutional court model was born was that of the nineteenth century Europe which was dominated by the doctrine of legislative supremacy which held that the legislature was the only legitimate governmental body representing the people and therefore the legislature was the only supreme expression of the general will. Kelsen's innovation was to create a court that without opposing the idea of parliamentary supremacy still allows control of the product made by the legislature: laws. Unlike in the US where ordinary judges can review and even strike down legislations, in the Kelsenian model, only specialized court can do so. These courts are called ${ }^{58}$ the Constitutional Court in Benin, the Constitutional Chamber in Burkina Faso and the Constitutional Council in Senegal.

\footnotetext{
${ }^{57}$ Hans Kelsen, an Austrian jurist was famous for being a co-drafter of the 1920 Austrian Constitution. As an expert of constitutional law, he is known for having written the six main parts of the constitution detailing the organization and procedures of a constitutional court. Australia then became the first to introduce a specialized constitutional jurisdiction that later served as a model for many Europeans countries.

${ }^{58} \mathrm{I}$ am using the names used in the initial constitution as things have changed over the time. The reason is that my study is mainly interested in knowing whether the initial constitutional designs have contributed or not in protecting the constitution against non-consolidating amendments.
} 
Table 18: summary of Judges nomination process

\begin{tabular}{|c|c|c|c|c|c|c|}
\hline & $\begin{array}{l}\text { Judges' } \\
\text { selection }\end{array}$ & $\begin{array}{l}\text { Nominees' } \\
\text { year of } \\
\text { experience } \\
\end{array}$ & $\begin{array}{l}\text { Number of } \\
\text { Nominees \& } \\
\text { expertise }\end{array}$ & $\begin{array}{l}\text { Selection of } \\
\text { court president }\end{array}$ & Term in office & $\begin{array}{l}\text { Removal } \\
\text { procedures }\end{array}$ \\
\hline Benin & $\begin{array}{l}\text { President \& the } \\
\text { National } \\
\text { Assembly }\end{array}$ & $\begin{array}{l}\text { At least } 15 \\
\text { years. }\end{array}$ & $\begin{array}{l}3 \text { magistrates, } \\
2 \text { legal experts, } \\
2 \text { personalities }\end{array}$ & $\begin{array}{l}\text { Vote among } \\
\text { members }\end{array}$ & $\begin{array}{l}5 \text { years } \\
\text { renewable once }\end{array}$ & $\begin{array}{l}\text { Cannot be } \\
\text { removed }\end{array}$ \\
\hline Burkina Faso & $\begin{array}{l}\text { President \& the } \\
\text { president of the } \\
\text { National } \\
\text { Assembly }\end{array}$ & $\begin{array}{l}\text { Not specified } \\
\text { in the } 1991 \\
\text { constitution }\end{array}$ & $\begin{array}{l}3 \text { magistrates, } \\
6 \text { personalities }\end{array}$ & By the president & $\begin{array}{l}9 \text { years non- } \\
\text { renewable }\end{array}$ & $\begin{array}{l}\text { Cannot Be } \\
\text { Removed* }\end{array}$ \\
\hline Senegal & President & $\begin{array}{l}\text { Not specified } \\
\text { in the } 2001 \\
\text { constitution }\end{array}$ & $\begin{array}{l}\text { Five judges, } \\
\text { Expertise not } \\
\text { specified in the } \\
\text { initial } 2001 \\
\text { constitution }\end{array}$ & By the president & $\begin{array}{l}\text { Six years non- } \\
\text { renewable }\end{array}$ & $\begin{array}{l}\text { Cannot be } \\
\text { removed }\end{array}$ \\
\hline
\end{tabular}

*In 2007, the President of the Constitutional Council was removed through a presidential decree. 
The Benin Constitutional Court is composed of seven members of which, four members are appointed by the bureau of the National Assembly and three by the President of the Republic for five years renewable once ${ }^{59}$. Article 115 of the Beninese constitution states that to be member of the constitutional court one needs not only to show professional competence, but also he or she needs to be of good morality and good integrity. The court is made of: three magistrates with at least fifteen years of experience two of which are appointed by the National Assembly bureau and one by the President of the Republic; two legal experts with at least fifteen years of experience one of which is nominated by the president and the other by the bureau of the National Assembly; two personalities of great professional reputation one of which is appointed by the president and the other by the bureau of the National Assembly. The court is accessible to anybody. One does not need to be a Beninese citizen to access the Constitutional Court. The members of the Constitutional Court cannot be removed while in office unless they have committed an offence and were caught in the act. In this case the President of the Constitutional Court and the President of the Supreme Court should be informed in no later than forty-eight hours. In Benin, the President of the Constitutional Court is elected by his colleagues. This is not the case in Burkina Faso where the President of the Constitutional Chamber is the President of the Supreme Court, who is appointed by the President of the country.

In Burkina Faso, the term used to refer to the special court that oversees the constitution is Constitutional Chamber that is part of the Supreme Court. The Supreme

\footnotetext{
${ }^{59}$ The composition is spelled out in Article 115 of the Benin 1990 Constitution.
} 
Court is composed of four chambers: the constitutional chamber, the judiciary chamber, the administrative chamber, and the court of auditors. The Constitutional Chamber of Burkina Faso is composed of: three magistrates nominated by the President on suggestions from the minister of Justice; three personalities named by the President; three personalities named by the president of the National Assembly. Beside the President of the Supreme Court, ${ }^{60}$ who is also the president of the Constitutional Chamber, the rest of the members are appointed for nine years non-renewable. The members are renewed for a third of them every three years. There are five personalities allowed to access the Constitutional Chamber: the President, the President of the National Assembly, the Prime Minister, and the President of the Chamber of Representatives and 1/5 of the National Assembly members ${ }^{61}$.

In Senegal the court is called Constitutional Council, as in France. It is composed of five members: a president, a vice-president and three associate justices. They have a non-renewable six-year mandate. The Council is renewed every two years. Either the president is renewed or two members of the Councils are renewed. The five members of the Senegalese Constitutional Council are all appointed by the President of the country. The 2001 Constitution states ${ }^{62}$ that conditions for eligibility as a member will be decided through an organic law.

There is a consensus in the literature that judicial independence is a valuable asset for the rule of law and good governance (Cross, 2008). Judicial independence is better understood as a notion of conflict resolution by a neutral third party that can be trusted to

\footnotetext{
${ }^{60}$ Article 152 of the Burkina Faso 1991 Constitution.

${ }^{61}$ Article 157 of the Burkina Faso 1991 Constitution

${ }^{62}$ Article 89 of the 7 January, 2001 Senegalese Constitution.
} 
impartially settle controversies (Shapiro, 1981). Although there is not a single best definition of judicial independence, the literature gives us some clues that are the key elements, or indicators used to determine judicial independence in a given country (Keith, 2002). Among these indicators are the: selection of judges, the constitutional guarantee of their term in office, their salary, and their removal from office. In this particular section I am focusing my attention on the appointment of constitutional judges. My working assumption is that the more independent a constitutional court is the better equipped it is to protect the constitution against politically motivated amendments. Now that I have described how judges are appointed in my case study countries, time has come to answer the two-fold question of whether the selection of judges shows some judicial independence in Benin, Burkina Faso and Senegal and whether that judicial independence contributes in helping the courts protect the constitution against undue amendments. Which country seems better equipped constitutionally speaking?

According to the Francophone Constitutional Courts Association, ACCPUF ${ }^{63}$, the appointment process is one of the most important elements of judicial independence. I am paying a particular attention to the criteria endorsed by this association as the most important signs of judicial independence, because all my case study countries are members of the association whose main goal is to promote the rule of law in the respective member countries. At their 2006 meeting at Bucharest (Romania) $)^{64}$, the

\footnotetext{
${ }^{63}$ ACCPUF means Association des Courts Constitutionnelles ayant en Partage l'Usage du Français. This association of Francophone constitutional courts has more than forty members. Information about the association can be found at http://www.accpuf.org/. I am using the association's concept of judicial independence. Who else than the members of this association knows what independence means for a constitutional court? Moreover, my case study countries are all members of this association which main goal is to contribute to the consolidation of the rule of law in its member countries.

${ }^{64}$ It was May 31 and June 1rst. Information on the meeting can be found at the association website: http://www.accpuf.org/
} 
members enumerated what they believe are the most important indicators of judicial independence: the Judge's selection process, the inability of politicians to remove judges from office, judges' salaries, and the constitutionalization of constitutional courts. When it comes to staffing the court, diversity among government officials who get to select judges is viewed as a way to preserve judicial independence. In other words, it is not recommended that a president be given the authority to appoint all members of a constitutional court, as it happens in Senegal. This is against the spirit of judicial independence as Hans Kelsen, the father of the constitutional court, designed it (Salami, 2005, p. 312).

According to this author, the case of Senegal is made worse when considering the irrevocability element. In Senegal even though the law states that judges are not removable while in service, government officials can circumvent the law using the Superior Council of Magistrates to move magistrates against their will. This happens because the Superior Council of Magistrates, which is the institution in charge of disciplining and checking on judges, is presided over by the President of the country. It makes one wonders how a judicial independence can be effective when the authority that judges need to be protected from is the one to lead the highest institution with the power to oversee judges (Salami 2005, p. 299). Moreover the Justice Minister is the one with the power to designate judges who get to move into higher hierarchical positions and who consequently get better pay. As one can notice this particular remark refers to ordinary judges, but it is worth mentioning as the Senegalese Constitutional Council unlike the one in Benin is hosted inside the judiciary institution. 
The Beninese court is separated from the judiciary. The constitution provides a whole title ${ }^{65}$ for the Constitutional Court. Four of its court members are appointed by the bureau of the National Assembly and three by the president of the country. An interesting aspect that worth noting is that the members selected by the bureau of the National Assembly are not chosen by one person, namely the president of the National Assembly as it happens in Burkina Faso or in France. ${ }^{66}$ In Benin, the decision is made by a group: the bureau of the National Assembly. The jurisprudence of the court gives us a sense of how it works. In a $1998^{67}$ opinion, the Beninese Constitutional Court voided all the nominations made by the National Assembly bureau on the grounds that the presidents of the Assembly committees were not consulted according to Article 18-b of the National Assembly rules of procedures. The Benin constitution is the only one (among my three cases) to state clearly what conditions are required to be a member of the Court. It also requires that the president of the Court be not only chosen by the members of the Court, but that she or he be chosen among the high quality law specialists and the magistrates appointees. Actually, the qualification requirement in the Beninese Constitution supports the idea that the Beninese constitutional framers intended to make this institution a strong one (Fondation Konrad Adenauer, 2009, p. 200). The Senegalese Constitution only mentions that these conditions will be determined later through an organic law. The Burkina Faso Constitution, after indicating that three magistrates are appointed by the president, vaguely adds that three other personalities are names by the president and that

\footnotetext{
${ }^{65}$ Title V

${ }^{66}$ As a reminder, I am using the initial constitutional documents (the Beninese 1990 Constitution, the Burkinabe 1991 Constitution, and the Senegalese 2001 Constitution) as the basis for my analysis, as things have change since these documents were adopted. Even in France, there is now a way parliament members are given control over the nomination process (Ponthoreau \& Hourquebie, 2009, p. 86)

${ }^{67}$ DCC $98-53$ du 29/05/1998
} 
the National Assembly president also gets to nominate three personalities, without saying what is enclosed in the concept of personality.

In the light of this quick comparative look at the three countries I argue that the Beninese Constitutional Court is better equipped to deal with unwanted amendments than the other two courts. Taking into account that the Francophone Constitutional Courts Association advises diversity among the authorities allowed to select the constitutional court members as a factor of judicial independence, I argue that the setting chosen by the Beninese framers ${ }^{68}$ is closer to the ideal of judicial independence. In these three countries as in other Francophone African countries, the executive power is known to dominate the other two branches of the government (Fall, 2008). Giving constitutional powers to the president to appoint all members of the court, as it happens in Senegal, does not seems to favor the kind of judicial independence that is known to be important for the prosperity of the rule of law. Due to the domination of the executive power, the choice made by the Burkinabe framers does not look very promising either when considering the concept of judicial independence and how to secure it. In Burkina Faso the president gets to choose six of the constitutional chamber members plus the president of the court who happens to be the president of the Supreme Court. And we know how important the role of any president of a court is. She or he is generally the one to control the court's procedures and to choose among the members who gets to draft the court opinions (Rotman, 2004, p. 297). Moreover, Article 18 of the 2000 organic law on the Constitutional Council gives exceptional voting power to the president of the Council ${ }^{69}$. When the Burkinabe Council

\footnotetext{
68 This is called Shared Appointment (Volcansek, 2007, p. 376)

${ }^{69}$ Article 18, third clause: «En cas de partage égal de voix, celle du Président est prépondérante ». It is worth mentioning that the Burkinabe Constitutional Council has changed its name to become the constitutional
} 
members are equally divided on an opinion ( 5 versus 5 , since there are 10 members), the opinion of the president prevails. Three members of the court are chosen not by the bureau of the National Assembly as in Benin, but by the President of the National Assembly who usually happens to be member of the sitting president's party, the same party that has the majority in the parliament.

The precision makes sense, because one can argue when it comes to Burkina Faso, that all members of the constitutional council are chosen by one person, namely the president as he and his party chose all the members. Judicial independence seems more compromised in the case of Burkina and Senegal as there is no confirmation process through the Senate as it happens in the US. In Benin, the process is more transparent not only because the National Assembly gets to choose more members (four) than the president, but also as the 1998 case shows, the National Assembly nominees are chosen by the bureau of the Assembly and through a process in which the members of the parliament take part. The constitutional setting chosen by the Beninese framers when it comes to the selection of the constitutional court members mirrors or reflects the ideal of constitutional court. In conclusion, I think the Beninese selection process is more transparent and that this transparency translates into a better quality of its members and more independence for the Court. As a result the Benin court is better equipped to fight against undue amendments as it has been given more constitutional powers than the other courts. 


\section{Tenure of Constitutional Judges}

As with the selection, the debate on the tenure of judges takes place in the context of the desire for judicial independence. The question is how to design judges' terms in office that insulates them and their office enough from external pressures so as to allow them to freely do their business of adjudication. To tackle this equation various countries have various solutions. Common law countries are known for their lifetime or longer tenure time for judges compared to civil law countries. In the United States, Article III judges $^{70}$ enjoy life tenure. Today, there is an ongoing debate about how wise the practice of life tenure for judges is. Is it not too high a price to pay for judicial independence? How efficient is life tenure in securing judicial independence, as this practice of life tenure exists nowhere else in the world besides the US and Russia (Calabresi \& Lindgreen, 2006, p. 819).

Often when debating life tenure in the US people tend to focus on the nine justices of the Supreme Court even though the many other US Courts of appeal judges are also Article III judges. Actually, Article III does not state explicitly that federal judges serve for life. It is only implied in the provision that "The judges, both of the Supreme Court and inferiors Courts, shall hold their Offices during Good Behavior." "Good behavior" is a concept borrowed from English law (Mazza, 2003, p. 132). The author cites the spring 1788 Hamilton federalist argument that ties judges' life tenure to judicial independence. After all, the judiciary is the least dangerous branch of the government as it exercises "no influence over either the sword or the purse." This assumption has since then been attacked by anti-federalist Robert Yates who argued that

\footnotetext{
${ }^{70}$ Article III judges is jargon used to refer to the US federal judges that have traditionally enjoyed life tenure (Mazza, 2003, p. 131)
} 
life tenure put judges above any control and that men put in such conditions will certainly feel "independent of heaven itself" (Mazza, 2003, p. 135). The argument here is that judges do not need such a high degree of insulation to efficiently fulfill their mission (Ferejohn, 2002, p. 59). Independence is a cardinal virtue for the judiciary, but complete insulation is necessarily a bad idea, because there should always be some political control over the judiciary. This is called optimizing rather than maximizing judicial independence (Fiss, 1993, p. 66). There are many arguments against life tenure for judges. One of them is that appointing judges for life does not respect the spirit of representative democracy that requires holding officials accountable to the people. With life tenure judges stay too long on the Court and because of their insulation from the public, they become too detached from reality. Who then are judges accountable to, once appointed for life? Plus, judges as policy makers act like legislators, why should they not be submitted to periodic elections or recalls like other legislators (Senators, representatives, and the president)? Critics of life tenure judgeship also point to mental and physical problems due to age that might negatively impact judges' decisions. Moreover, judges have, in the past, used strategic retirement, only leaving office when the party they support is in power so that the president can get to appoint a judge of similar views to the one who is retiring.

Proponents of life tenure usually defend the practice on the grounds of judicial independence. Life tenure for judges has the invaluable advantage of insulating judges from outside pressures. Article III judges have reached the end and the top of their career and have no concerns about any future political appointment. They do not need to please any political party in an effort to secure reappointment. Life tenure provides stability as 
individual judges usually do not reverse course on decisions they make (Ward Farnsworth cited in Stras and Scott 2006). With shorter term limits for judges, constitutional law would change more rapidly putting at risk public trust in the legal system as a whole. The Supreme Courts records of Rhode Island and New Hampshire, the only two states in the US with life tenure show that they overruled themselves only two times and six times respectively (Stras \& Scott, 2006, p. 1424). Actually, the slow legal change that goes with lifetime tenure is consistent with the doctrine of stare decisis that is characteristic of the common law tradition. Moreover slow legal change carries a powerful message of consistency in the law, which in turn helps build trust in the judiciary, particularly, when the judiciary is consistent in its decisions. Critics of life tenure argue that long term limits can be as effective in providing necessary independence for the judiciary as life tenure does. The problem with this assumption is that without life tenure judges will need to think about their life after office. Judges might be led to cast their votes not necessarily according to the law and to their conscience but rather according to some serious calculations that improve their prospect for future employment once out of office.

Critics of life tenure have various solutions on how to address the issue. Some suggest term limits for federal judges through a statute (Mazza, 2003; Carrington \& Cramton, 2006), while others believe the appropriate way should be through constitutional amendment (Kurland, 1969; Calabresi \& Lindgreen, 2006) who remind us that constitutional amendment is how presidential tenure was resolved with the $22^{\text {nd }}$ Amendment to the US Constitution. Proponents of life tenure such as Stras \& Scott (2006) agree that few scholars came in defense of life tenure even though there is no real 
compelling argument against it. Others believe that life tenure is the greatest mistake the US constitutional framers made (Powe, 1998) and that it is an outdated practice from England. The prevalence of this practice in the US is certainly due to the false American assumptions that life tenure is necessary to preserve judicial independence (Calabresi \& Lindgreen, 2006, p. 774). Without going further in the US debate on life tenure, describing it helps me set the stage by reviewing the major questions related to judges' tenure. Are judges given too much power so as to create what is known in France as $L e$ gouvernement des juges ${ }^{71}$ How much should judges be insulated to efficiently do their job? Does life tenure achieve the goal of judicial independence as its proponents suggest? How can one isolate life tenure and confirm that it is the only strongest factor that secures judicial independence? If life tenure is the greatest factor of judicial independence why is it not so popular around the world?

According to Calabresi \& Lindgreen (2006), even England from where the US founders obtained the practice of life tenure has gotten rid of the practice. There is a mandatory retirement age of 70 years after which a judges is not allowed to serve. Constitutional judges serve nine years non-renewable in France. Judges in Italy, Germany, Portugal and Spain serve fixed terms of between six and twelve years. In Italy and Germany it is 12 years with a 68 years mandatory retirement for the Germans. In Spain, judges serve a twelve-year renewable term. In Portugal it is a six-year term. In Canada there is a retirement age set at seventy-five, while in Australia it is set at seventy. In India, it is sixty-five. In the US, beside the federal government and Rhode Island, all the rest of the states in the country rejected life tenure for their courts of last resorts

\footnotetext{
${ }^{71}$ See (Favoreu, 1988, p. 93)
} 
(Calabresi \& Lindgreen, 2006, p. 820). The authors use these examples to make their case that life tenure for judges is undesirable. They suggest that if the US framers were reconvened today they would probably not go for this practice, because the US Supreme Court is far more powerful than what Alexander Hamilton anticipated when he suggested that the judiciary was the feeblest branch of the government. According to the literature presented above, there are more countries and states without life tenure judgeship than with life tenure. Many common law countries such as Canada, England, South Africa, and Australia have chosen for a mandatory retirement age.

None of my case study West African countries has a life tenure judgeship. Article 115 of the 1990 Beninese Constitution sets the tenure of judges at five years renewable once. Article 153 of the Burkinabe Constitution provides for a single term of nine years for all the members of the Constitutional Chamber, but the president. Every three years a third of the members are renewed. In Senegal, Article 89 of the 2001 initial Constitution provides for a six-year non-renewable membership of the constitutional council. According to a survey done by the Francophone Constitutional Courts Association ${ }^{72}$ among its members, the major aspect pointed out as a sign of independence is the inability of government officials to remove judges from office. Le Principe d'inamovibilité is a French concept used to describe a set of conditions related to judges' terms in office considered to provide independence. This principle includes the principle of no reduction of salary and the inability to remove judges without adequate procedures. The notion of removal here is interpreted to mean that judges cannot be offered promotion that might require them to move from one city to another or from one office to

\footnotetext{
${ }^{72}$ See www.accpu.org bulletin number 7
} 
a different one. In Senegal, constitutional judges have the same type of immunity given to the members of parliament. Life tenure is not mentioned as a major factor of judicial independence. However, renewal of tenure is viewed as a factor against judicial independence as judges could make decisions in the hope of tenure renewal.

My initial assumption in this section is that constitutional courts with unsecure tenure settings would easily be influenced, because judges that fear for their job would tend to vote in favor of the authority holding the power of reappointment or removal. Consequently, judicial independence would be jeopardized and without judicial independence, constitutional judges are powerless when it comes to protecting the constitution against politicians' activism. These particular assumptions are supported by the literature (Farnsworth, 2006; Stras \&Scott, 2006). None of the three countries under my study provides for life tenure however, the principe d'inamovibilité in these countries serves the same purpose of offering judges enough independence while in office. My task in this section is to analyze the three cases (Benin, Burkina Faso and Senegal) in the light of the literature and the practices in advanced democracies such as the US to see whether the settings of their respective constitutions favor judicial independence.

The Francophone Constitutional Courts Association raises the issue of tenure renewal as limiting independence for the judiciary. Benin is the only country of the three where renewal of tenure is offered. Moreover, there is a problem with the renewal notion as all the judges arrive at the court at the same time. The prospect of their leaving at the same time poses the question of waste of experience (Fondation Konrad Adenauer, 2009, p. 203). In five years of tenure judges acquire experience that they could share with new comers if they were to stay on the court. In Burkina Faso this particular issue is addressed 
through a renewal of one third of the council members every three years. This suggests that judges do not come to the courts at the same time. In Senegal either the president of the council or two of the judges are renewed every two years. ${ }^{73}$ Does this means that constitutional courts in Senegal and in Burkina Faso are more independent than the Beninese Court? Actually we should not read too much into the tenure of judgeships in these countries. The conclusion that can safely be drawn from the tenure settings in the three countries is that the design adopted by Senegal and Burkina Faso is closer to what is done in the majority of countries with constitutional courts ${ }^{74}$. The question of what constitutional court is more independent, however, cannot be answered here as the discussion continues through the analysis of other factors of judicial independence such as the removal of judges from the court. In the next section I take a look at the procedures that are used in each of my study countries for removing judges. How do these procedures impact judicial independence?

\section{Procedures for removal}

The justification for studying judges' removal is similar to the one used for judges' appointments. If judges can be removed from office at the pleasure of some politicians, their decisions on the court would necessarily be influenced, particularly in cases where the authority with the power to remove them is involved. Article III, section 1 of the U.S. Constitution states:

"The judicial Power of the United States, shall be vested in one supreme Court, and in such inferior Courts as the Congress may from time to time ordain and establish. The judges, both of the supreme Court and inferior Courts, shall hold their offices during good Behaviour, and shall, at stated

\footnotetext{
${ }^{73}$ Article 89, clause 2 of the initial Constitution. Since the law changes quickly in the countries I am studying, it is important to keep in mind that I am mainly talking about the initial constitutions.

${ }^{74}$ See www.accpuf.org.
} 
times receive for their Services a Compensation, which shall not be diminished during their Continuance in Office."

Even though this article seems clear enough to understand, because Congress is mentioned in the article, some lawyers and lawmakers have construed it to mean that Congress has the power to remove judges for anything which two third of the Senate finds to be "ill behavior" (Brant, 1972, p. 9). According to the author, this was never the intention of the framers who debated the issue and came out with the clause "high crimes and misdemeanors" that is in the Constitution.

The first time impeachment against a judge was used in the U.S. was in 1805 with Justice Samuel Chase. One of the grievances in the 1776 Declaration of Independence against the King of England was that king George "has made Judges dependent on his Will alone, for the tenure of their offices, and the amount and payment of their salaries" (Steven, 1984, p. 218). The reasoning here is that judges beholden to the king were not providing protection against arbitrary behavior by the king and his government. The American Revolutionaries wanted an independent judiciary. Thomas Jefferson is well known and respected for being the author of the 1776 Declaration of Independence. Yet after he became president in 1801, he wanted to replace judges appointed by George Washington and John Adams. Since 25 of the 34 Senators were members of the Republican Party, President Jefferson knew he could use impeachment as a way to remove Federalist judges in order to appoint judges who shared his views. Justice Samuel Chase, even though he violated no law, was impeached by the House of Representatives and placed on trial before the Senate in February 1805. He was acquitted on all counts. What happened is that the American people realized the importance of what was at stake. 
It was not just Justice Chase who was on trial. Actually, it was the independence of the judiciary that was on trial (Steven, 1984, p. 220)

In 1970, there was an attempt to impeach Justice Douglas. In his speech of April 15, 1970, Republican Minority leader Gerald C. Ford stated that: "the only honest answer is that an impeachment offense is whatever a majority of the House of Representatives considered it to be at a given moment of history; conviction results from whatever offense or offenses two-thirds of the other body considers to be sufficiently serious to require removal of the accused from office.” This interpretation is far from the truth according to Brant (1972). Actually, impeachment, as it is known in the US Constitution finds its origins in the fourteenth century England where it was used. The United States constitutional framers readapted the concept of impeachment to prevent abuses made of this concept by kings in England. ${ }^{75}$ On August 27, 1787 at the Philadelphia Convention, John Dickinson of Delaware proposed that to the sentence "The Judges of the Supreme Court and of the inferior courts, shall hold offices during good behavior" there should be added the words "provided that they may be removed by the Executive on the application of the Senate and House of Representatives", Governor Edmond Randolph of Virginia replied by making the point that adding this clause would significantly weakened the independence of the judges. Passion if not restricted by constitutional safeguard, can always work its way from politics into law, since laws are interpretable by politicians. If let to their own sense of self-restraint, the House and Senate (particularly when in the hands of one political party) can twist the concept of "high crime and misdemeanors" into an unlimited power of impeachment (Brant, 1972, p. 23). The American framers by

\footnotetext{
${ }^{75}$ For details in this particular use of impeachment in England, see Brant (1972)
} 
making Congress responsible for judicial discipline certainly did not want to leave judges in precarious conditions of being removed for any misbehavior. In fact, the Philadelphia convention did not approve misbehavior as a constitutional ground for judges' removal. Was it wise to hand the responsibility of judicial discipline to the legislative branch? Who should judge the judges? This is a question that Braithwaite (1971) tackled without any definitive response.

By going through American history to discuss impeachment procedures, I am making the point that judges' removal procedures constitute an important factor for the independence of the judiciary. In the US where the federal system provides for many veto players and checks and balances, it still happens that politicians under passion, try to abuse their powers. The lesson to be drawn from the attempt impeachment of Justice Chase is that constitutions can be well-designed to protect judges against politicians' abuses, but it often takes support from well-intended individuals to save the day. In the case of Justice Chase, members of the Republican Party knowing what was at stake, decided to vote independently of their party to acquit him for the sake of judicial independence. This scenario would be unlikely in any of my case study countries, not only because there are few strong individualities as in the US, but also because of the too strong party discipline that could prevent any individual Senator from acting independently. However, if there is not much to expect from individual politicians when it comes to protecting judicial independence, is there any hope on the institutional side that can help protect judicial independence when it comes to judges' removal? This is the question I am taking on by presenting the constitutional designs of my case study countries that address procedures of judges' removal from their office. 
Article 115 of the Beninese Constitution states that constitutional court judges cannot be removed from office during their tenure. They cannot be subjected to law suits or put under arrest without the authorization of the constitutional Court and the bureau of the Supreme Court sitting in a joint session except, for the cases of flagrant misdemeanors. In such situation, the president of the constitutional court and the president of the Supreme Court should be immediately informed not later than forty-eight hours. The real meaning of this article is that the Beninese Constitutional Court is fully responsible for the discipline of its members. According to the constitutional design chosen by the framers, no politician should be involved in the business of disciplining judges. It is a choice made to guarantee judicial independence for constitutional judges (Fondation Konrad Adenauer, 2009, p. 202). As the Association of the Francophone Constitutional Court suggests, this is a common trend of policy-making in the matter of constitutional judges' discipline in civil law countries ${ }^{76}$ In other words, contrary to the practice in the U.S. where Congress is responsible for judges' discipline, in most civil law countries with constitutional courts, the matter of judges' discipline is in the hands of judges themselves. Actually, in certain countries like Senegal there is no procedure for disciplining judges. Because members of the Senegalese Constitutional Council are subject to a 40 -year ${ }^{77}$ minimum age and a 25 -year professional experience requirements, they are supposed to be wise enough to stay out of troubles. This is supposedly the reason why there is no disciplinary procedure (Salami, 2005). The Beninese and the Senegalese courts seem to be independent from other government branches on the matter of judges' removal. Are there clear cases in the jurisprudence of these courts to attest such

\footnotetext{
${ }^{76}$ See http://www.accpuf.org, bulletin n:7, section II

77 These requirements were not included in the initial constitution of January 2001.
} 
independence? This particular question was used by the Francophone Association of Constitutional Courts that includes all my case study countries. The association asked it member courts to answer the question whether they are really independent from the executive and the legislative branches. The answer needed to be supported by concrete examples of cases to attest to that independence. The association regularly conducts these types of surveys for comparative constitutional analysis purposes. The Beninese Court provided many examples of cases, the Senegalese court gave a few cases, but the Burkinabe court did not provide any answer to the question.

Because the Beninese Constitution ${ }^{78}$ allows citizens to access the constitutional Court either directly or through a procedure called l'exception d'inconstitutionnalité $e^{79}$, Mme Soglo and also the Pan-African women's association WILDAF (Women in Law and Development in Africa) section of Benin, on Jun 24, 2002, called on the Constitutional court ${ }^{80}$ to review the constitutionality of the Beninese family code. In its article 143 , the Beninese family code allowed two forms of marriages: monogamy and polygamy. The second clause of the cited article provides for polygamy for men, but

\footnotetext{
${ }^{78}$ Article 22 states: "tout citoyen peut saisir la Cour constitutionnelle sur la constitutionnalité des lois, soit directement, soit par la procédure de l'exception d'inconstitutionnalité invoquée dans une affaire qui le concerne devant une juridiction. Celle-ci doit sursoir jusqu'à la décision de la Cour constitutionnelle qui doit intervenir dans un délai de trente jours. Article 3 in its second clause states : «Tout loi, tout texte réglementaire et tout acte administratif contraires à ces dispositions sont nuls et non avenus. En conséquence, tout citoyen a le droit de se pourvoir devant la Cour constitutionnelle contre les lois, textes et actes présumés inconstitutionnels.

${ }^{79}$ L'exception d'inconstitutionnalité is a way that can be used to access the constitutional judges when an individual citizen or a corporation raises a prejudicial question of unconstitutionality during a trial. In other words, a citizen can put in doubt the constitutionality of a law by suggesting that a law, as it is, goes against his individual rights. When that happens, the trial needs to be put on hold until a decision is made on the issue of unconstitutionality raised. There are two ways to deal with the issue. The first one is that the judge responsible for the trial responds to the question of unconstitutionality and proceeds to take on the initial issue at trial (this is how it works in the U.S.), or he must refer the question of unconstitutionality to the constitutional Court before he can proceed to decide on the initial problem at trial. The second way is how things happen in countries with constitutional courts, because there, the constitutional court is the only court with the power to decide on constitutional matters.

${ }^{80}$ See paper written by Stéphane Bolle at: http://afrilex.u-bordeaux4.fr/
} 
adopted monogamy for women. The Beninese Constitutional Court struck the law down on the ground that it violates Article 26 of the country's constitution that clearly provides for equality between men and women. The Court also voided the first clause of Article 12 of the same code, on the ground that it does not allow women to keep their family name once married, while men can keep theirs. According to the Court, marriage should not make women lose their identity. This decision made headline in the news and put many National Assembly members on the defensive. Some of them suggested that the Court abused its power and considered the Court's decision a "coup d'état" (Salami, 2005, p. 281). By declaring the two articles void, the Court made suggestions on how the National Assembly could correct the code to make it constitutional. The Court suggested that the National Assembly members could keep polygamy in the code if they wanted to, but they would also need to allow polyandry for women. That way, there would be no discrimination between men and women. These suggestions were viewed as offensive to the National Assembly which opposed the suggestions. Some (Nestor Hossou of the Social Democratic Party) suggested that women were taking control of the country considering that the president of the Beninese Constitutional Court (Mme Ouinsou) was also a woman. On June 14, 2004, accepting the suggestions from the Court, the National Assembly passed the law with 57 votes for, zero votes against and eight abstentions. This case is particularly interesting, as it shows how the Beninese Court was able to use its power to advance women rights. Actually, the Court did not prohibit polygamy. It suggested that the National Assembly add polyandry for the sake of equality between men and women if the members wanted to keep polygamy. The legislators chose not to accept polyandry, as it does not exist in the Beninese culture. Having chosen to reject the 
notion of a woman with multiple husbands, the immediate consequences for them was that they could not keep polygamy. The country ended up with a family code with neither polygamy nor polyandry which is okay with the Court. The Beninese constitutional Court jurisprudence includes plenty of daring cases that challenged and disciplined both the executive and the legislative.

Article 53 of the Beninese Constitution requires that before taking office, the newly elected President of the country take an oath "before God, the souls of our ancestors, the nation and before the Beninese people, the only sovereign..." ${ }^{\prime 1}$ During the Beninese revolution led by President Kérékou in 1972, and due to his Marxist-Leninist views, all religions including vodu (the country's traditional religion) were forbidden. In 1990, Kérékou became Christian (a protestant) and he was well-known for his devotion and zeal for this religion. When taking his presidential oath on April 4, 1996, he omitted the following portion of the Oath dealing with "the souls of our ancestors" a phrase purposely included in the constitution by the framers to remind the Beninese about their attachment to their ancestral culture and religious beliefs. Two citizens immediately sent requests to the Constitutional Court in order to void and restart the presidential oath as the now protestant president might have intentionally decided to omit the portion of the oath that stresses the Beninese traditions. Actually, there is nothing in the Beninese constitution that suggests that the Court has the authority to control or make the president do his oath over. The Court still found a way to void the presidential oath and make President Kérékou take it again on the ground that the presidential oath is indivisible and had to be read entirely. No modification or omission is allowed. President Kérékou took

\footnotetext{
${ }^{81}$ This is my own translation of a portion of Article 53.
} 
the oath a second time and said this: "In Benin, even generals bow down before the Constitution" (Salami, 2005, p. 115). Another decision ${ }^{82}$ about a decree made by a minister on amnesty given to soldiers, was voided by the Court on the ground that Article 98 of the constitution states that amnesty is a domain of the law and a decision about amnesty cannot be made through a ministerial decree. The attitude of the Beninese Court and the extended power that it seems to have given itself, made some scholars talk about la "Republique des juges." ${ }^{83}$ The same notion used by former France president de Gaulle to describe the power of the judiciary in the United States (Salami, 2005)

The fact of the matter is that the Beninese Constitutional Court seems dynamic and very active in fulfilling its role of consolidating democracy. From June 1993 to July 2008, the Court decided more than 1700 cases, of which 1200 dealt with constitutionality. 602 cases were about human rights and public liberty (Tama, 2009, p. 161). This activism of the Beninese Court is in part due to the key constitutional power given to citizens to access the Court (Rotman, 2004, p. 294). The author points out that Article 121 of the Constitution allows the Court to act on its own motions ${ }^{84}$ and that the Benin's Court marks a radical departure from the French model and also from the German model that allows citizens to call on the Court to review laws. The German model institutes a filter, because petitioners have to prove that they have exhausted all other legal remedies before the Court can take a look at their case. In Benin, petitioners do not need any particular

\footnotetext{
${ }^{82}$ Décision CC96-064 du 26 septembre 1996: l'arrêté n³56/MDN/DC/SP-C du 30 juillet 1996.

${ }^{83}$ Stéphane Bolle at: http://afrilex.u-bordeaux4.fr/ . For a deeper understanding of the notion of République des juges or Gouvernement des juges see a book written in 1921 by the French scholar Edward Lambert entitled: le gouvernement des juges et la lute contre la legislation sociale aux Etats Unis. The book denounces the empowering of judges in the U.S. to set aside legislation as unwise (Tushnet, 2008, p. 1227). It might also be constructive to see Landfreid (1987, p.7)

${ }^{84}$ This jurisdiction is called l'auto-saisne.
} 
motif to request a constitutional review, a situation that allows the Court to be as activist as it is.

The activism of the Beninese Court went so far as to get its own president out of the Court. In 1998, at the end of her mandate Justice Pognon, the sitting president of the Beninese Constitutional Court was nominated by the bureau of the National Assembly for reappointment as a high-level jurist. A citizen in the name of Y. Kotchikpa called on the Court to review the constitutionality of this particular nomination which he believed was unconstitutional because Justice Pognon was initially nominated and served on the Court as a Magistrate. The constitution created three categories of members to sit on the Court: magistrates, high-level jurists and, personalities with great reputation for their professionalism. Since Justice Pognon was initially nominated as a magistrate, she cannot be reappointed as a high level jurist. On May 29, $1998,{ }^{85}$ the Court decided that citizen Y. Kotchikpa was right. Consequently, Justice Pognon, the sitting president of the Beninese Constitutional Court was not reappointed. She was ousted (Salami, 2005, pp. 137-138).

Compared to the Burkinabe and the Senegalese courts, the Beninese Court has a richer jurisprudence. On the particular issue of the judges' discipline or their removal, I already mentioned that the Senegalese Constitution designed no specific procedures, since as Constitutional Council members the judges are deemed wise. In Burkina Faso, the 1991 Constitution did not design specific procedures for the Constitutional Chamber members since the now Constitutional Council was part of the judiciary before the organic law of 2000. Judges were being disciplined by the Conseil Superieur de la Magistrature, an institution headed by the President of the country and his Justice

85 DCC 98-052 du 29 mai 1998 
Minister who is the vice-president. In 2000 an organic law ${ }^{86}$ was passed to change the status of the Constitutional Chamber, which became independent for the rest of the judiciary and now has a new name: Constitutional Council. From 1991 to 2008, the Constitutional council of Burkina Faso has examined around 490 cases with 426 cases in which the court's role was only to give opinions (see appendix 2). Twenty-four cases were on the control of constitutionality, and forty were on electoral issues (C.G.D, 2009, p. 135). These numbers show that the Burkinabe Constitutional Council functions more as a council than as a court due to its high number of opinions compared to cases where the Court actually made decisions. ${ }^{87}$ Moreover, when the Burkinabe Court was asked by its peers in the Francophone Constitutional Courts Association (ACCPUF) to provide examples of cases that can show the independence of the court either from the legislature or from the executive, the court replied that nothing shows that the Burkinabe court is not independent. The court did not or could not provide a single example to attest its independence vis-à-vis the legislature or the executive.$^{88}$ Furthermore, on September 5, 2007, a presidential decree was used to remove the president of the Burkinabe Constitutional Council from office. ${ }^{89}$

\footnotetext{
${ }^{86}$ Loi organique N: 011-2000/AN portant organisation, Attribution et Fonctionnement du Conseil Constitutionnelle et Procédures Applicables devant lui.

${ }^{87} \mathrm{I}$ am trying to make the point that the concept of opinion does not mean exactly the same in English and in French when it comes to the legal jargon. In English, the Court's opinion is not different from the Court's decision. In French, the word avis means opinion, it does not necessarily mean decisions. It only means that the Court was consulted about an issue, and it gave its opinion. The term "decision" is used by legal experts only when referring to the control of constitutionality of laws. It is also used when the court deals with electoral disputes (C.G.D, 2009, p. 135).

${ }^{88} \mathrm{http}: / /$ www.accpuf.org , bulletin n:7, November 2006, section II, p.161

${ }^{89}$ The initial constitution does not provide for the irrevocability of the Constitutional Chamber's members. It only sates in Article 160 that an organic law would regulate how the chamber functions. An important thing to be mindful of is that the president of the Constitutional Chamber is the president of the Supreme Court. There seems to be a gray zone left by the constitutional framers on the statute of this particular member of the Constitutional Council. Is he or she fully treated as a Constitutional Chamber's member or is he or she treated as a regular magistrate? If the council's president is a full member of this particular institution, it seems unconstitutional to remove him through a presidential decree
} 
In its study of the Burkinabe constitutional court's opinions and decisions, the most comprehensive recent study of this type, the Center for Democratic Governance, mentioned how difficult it was to access information about the court. This is due in part to the undeveloped nature of archives, but more importantly it is due to what the authors call the cult of secrecy ${ }^{90}$ in the Burkinabe judiciary, which makes any study on the system particularly difficult. But still, with the information gathered on the constitutional court cases from 1960 to 2008 , it is difficult for any researcher to point to particularly strong cases decided by the court in which the court challenged the legislature or the executive, the way the Beninese Court has done in numerous occasions. In contrast, it is easy to find cases in which the Burkinabe court has shown some lack of independence. In April 5, 2007, the Burkinabe Prime Minister ${ }^{91}$ called on the Constitutional Council to give its opinion on the contract of loan signed between Burkina Faso and the Islamic Bank of Development (IBD). The contract was signed in Ouagadougou on January 15, 2007. The first clause of Article 22 of the loan contract states that the contract is set to be executed under the Islamic Sharia law..$^{92}$ On April 20 2007, the Council argued that according to Article 31 of the Burkinabe Constitution, ${ }^{93}$ Article 22 of the contract is unconstitutional. In other words, Burkina Faso is a secular state, and accepting a contract that requires officials to use a loan according to Islamic sharia law might compromise this principle of secularity. On July, 05 2007, the Prime Minister contacted the Constitutional Council again for its opinion ${ }^{94}$ about the same contract with the Islamic Bank of Development. On

\footnotetext{
${ }^{90}$ (C.G.D, 2009, p. 3)

${ }^{91}$ Lettre n:2007-133/PM/CAB/ du 05 Avril 2007

92 «Le présent accord est soumis, pour son exécution et son interprétation, aux principes de la charia islamique » (C.G.D, 2009, p. 117)

${ }^{93}$ Article 31 states: «le Burkina Faso est un Etat démocratique, unitaire et laïc. Le Faso est la forme républicaine de l'Etat ».

${ }^{94}$ Lettre n:2007-381/PM/CAB/ du 05 Juillet 2007
} 
July, 20, 2007, the court reversed course. It argued that Article 22 of the contract earlier declared unconstitutional was now constitutional, even though Article 22 has not been modified (C.G.D, 2009, p. 117). According to the second clause of Article 159 of the Burkinabe Constitution, opinions or decisions of the constitutional council are not subject to appeal, since the Council is a court of last resort. Why did the Prime Minister submit to the Constitutional Council the same contract twice? On April 20, 2007, the Burkinabe Court made clear that Article 22 of the loan contract with the Islamic bank was unconstitutional. Under the Burkinabe Constitution, the Prime Minister did not have any authority to ask the Council for a second opinion, the opinions and decisions of the court being final, there is no appeal. If a Prime Minister has the power to make a constitutional council reverse its opinion, how independent such constitutional council actually is? Other examples that raise serious doubts about the Burkinabe Constitutional Council independence exist.

When asked by the Francophone Constitutional Court Association (ACCPUF), whether the Senegalese Constitutional Council thinks it is independent, the response was yes. Examples were given to substantiate that independence. In his March 28, 2001, decision, ${ }^{95}$ the Constitutional Council was asked by opposition parties - Parti Socialiste (PS), L'Alliance pour les Forces du Progres (AFP) and l'Union pour le Renouveau Democratique (URD) - to declare unconstitutional the fact that President Wade's name and picture were printed on a voting ballot in non-presidential elections in which President Wade did not take part as an individual. The Council agreed with the opposition parties and voided the voting ballot as unconstitutional. On August 13, 2003,

${ }^{95}$ Décision n²/E/2001, 3/E/ 2001, et 4/E/2001 en date du 28 mars 2001. 
thirteen opposition members of the Senegalese National Assembly called on the Council to invalidate an organic law that raised the number of the members of the Council of the Republic from 90 to 100 . The opposition parties argued that the party in power was creating financial charges without appropriate financial means. On August $29,2003,{ }^{96}$ the Senegalese Constitutional Council agreed with the opposition parties and declared the amendment to the organic law void. Other examples of the Senegalese Constitutional Council cases exist to show that at times the Council has challenged elected officials. However, as the former vice-president of the Court Babacar Kanté has pointed out, ${ }^{97}$ the Senegalese high court on constitutional matters is well known for its endless declarations of incompetence. In the fifteen years ${ }^{98}$ of its existence, the Senegalese Constitutional Council has only issued a little over hundred opinions and decisions (an average of seven opinions or decisions per year). Among these hundred opinions, about twenty cannot even be called decisions since they are just declarations of incompetence. ${ }^{99}$ Out of the hundred decisions or opinions of the Council, about half were issued on electoral matters. Thirty decisions or opinions were issued on the constitutionality of organic laws. ${ }^{100}$ Fifteen were issued on the constitutionality of ordinary laws. Two decisions were issued on international commitments. Four decisions were issued by means of l'exception

\footnotetext{
${ }^{96}$ Affaire n: 2C/2003 du 29 aout 2003

${ }^{97}$ (Fall, 2008, p.15). I am referring to the attitude of a Court that has the tendency to declare itself incompetent in deciding issues. This has happened so many times that the Senegalese Constitutional Council is often mocked for its constant declarations of incompetency.

${ }^{98}$ The Senegalese constitutional Council was created by the constitutional law 92-22 of May 1992.

99 (Fall, les Decisions et Avis du Conseil Constitutionnel du Senegal, 2008, p. 26)

${ }^{100}$ With the adoption of the January 22, 2001 Senegalese Constitution, important changes were made. Article 78 of the Constitution does no longer require anymore a check of the constitutionality of organics laws before their promulgation as required earlier by the March 7, 1963 Constitution.
} 
d'inconstitutionnalité ${ }^{101}$ Three decisions were issued on the constitutionality of constitutional laws, and three on the consultative opinions.

The problem is that judges in Burkina Faso and Senegal are not as audacious as their colleagues in Benin. They often chose for a literal interpretation of the constitution (C.G.D, 2009, p. 3). This can be explained by the scope of power given to these two courts compared to the Beninese Court. The Constitutional Council in Burkina and Senegal do not have auto-saisine (original jurisdiction) power. Any opinions or decisions on their part have to come from elected officials such as the Prime Minister, the President of the National Assembly, the President of the Chamber of Representatives, or the president of the country. Moreover, individual citizens are not given authority to call on the courts in these two countries as it happens in Benin. In other words, these courts were initially and maybe purposely weakened by the framers of their constitutions who did not provide them with enough power to guarantee their independence. In a brief conclusion, I will argue that when it comes to the removal of judges the Beninese Constitution provides for more protection than the other two constitutions. Consequently, the jurisprudence of the Beninese Court is not only richer, but it is also more dynamic in challenging the other two branches of the government for the sake of the rule of law and the consolidation of democracy.

\section{Conclusion}

This chapter intended to show that constitutional courts can be reliable institutional safeguard against politically motivated amendments if there are not used by

${ }^{101}$ This concept has been defined on page 189 
politicians just as window dressing institutions with no real power. In my study, I show that for a constitutional court to fulfill a mission of protection against undue amendments it must be given real constitutional powers that make it independent enough to freely conduct its business of control of the constitutionality of laws made by the executive and legislative branches of the government. I used three indicators to identify judicial independence. These three indicators are: the selection of judges, their term in office and their removal from office. My comparative analysis of Benin, Burkina Faso, and Senegal led me to conclude in regard to the selection procedures used in these countries that the Beninese process shows more transparency mainly because of the diversity of the authorities with constitutional power to select judges to the court. In Benin, not only is the legislative branch given more judges to select (four) compared to the executive branch (three), but the Beninese constitution instead of giving power to one person such as the president of the National Assembly to nominate judges, made it a shared responsibility among members of parliament. In other words more people are given authority to examine the selection process, which necessarily add to the idea of transparency in contrast to the Senegalese process that allows the president alone to select all five members of the constitutional Council. Moreover, the initial Senegalese Constitution does not give a clear idea of the qualifications of the members that the president is allowed to choose. This looks like too much discretion given to the executive branch already known for its overreaching behavior. In Senegal, almost all constitutional amendments come from presidential initiative 14 amendments out of 15 from 2001 to 2009 (Fall, 2011). The executive branch is too powerful (Fall, 2008). In Senegal, the parliament's agenda gives priority to the executive according to Article 84 of the 
Constitution (Thomas \& Sissokho, 2005). Based on this article proposal of amendments coming from parliamentarian can be postponed forever while executive drafts are examined. Article 82 is also another burden ${ }^{102}$ for the parliamentarians that show the supremacy of the executive (Thomas \& Sissokho, 2005, p. 106). In Burkina Faso, although there seems to be a diversity of authorities selecting judges to the Constitutional Chamber, the matter of fact is that because of the very powerful nature of the executive (the president's party is usually dominant in the parliament), the selection process ends up being done by officials from the same political party, which dilutes the diversity that is being sought for the sake of transparency. Moreover, in Burkina, other members of parliament have no business in the selection process. Only the president of the National Assembly is given constitutional power to select judges.

On the tenure of constitutional judges, my study shows that the Beninese Court because it allows a renewal of a five-year term for its judges does not fare well on this particular issue. The reasoning is that when judges hold renewable terms in office they tend to be lenient toward the authority with the power to renew their mandate. Another issues with the Beninese Court is that judges who get to the Court at the same time might be leaving altogether, which seems to be a waste of experience for the country. Such an issue finds a solution in the Senegalese and Burkinabe settings where a third of the courts members are renewed at certain intervals. Moreover, these two countries have a fixed term for constitutional judges. They only serve once, but unlike the Beninese Court whose members' salaries are set through a constitutional provision, the Senegalese and

\footnotetext{
${ }^{102}$ Article 82 of the Senegalese 2001 Constitution states that amendments from parliaments are disregarded once it is established that taking them into consideration would create financial public charges that are not provided for.
} 
Burkinabe council members have no constitutional guarantee of their salaries. This issue is addressed through a lower level of law (organic law). On this particular section of judges' tenure I conclude that the settings in Burkina Faso and Senegal look better that the ones in Benin not only because of the renewable term in office, but also because of the potential loss of experience that might occur if all Constitutional Court judges in Benin left at the same time.

Judges cannot be removed while in office unless they are accused of serious wrong doing. In such cases their removal is done with the consent of the Constitutional Court. They are not subject to law suits or arrests unless allowed by the Constitutional Court. This is how things are set through Article 115 of the Beninese Constitution. In Senegal and Burkina Faso the removal of judges was not clearly addressed in the initial constitutions as these institutions were part of the judiciary as a whole. The issue was addressed later through organic law on the Constitutional Council. In Senegal, constitutional judges have immunity similar to parliamentarians, however, there is no particular provision on how to treat a constitutional judge accused of wrong doing. The reason is that judges are deemed wise enough to avoid trouble. In Burkina Faso, before the year 2000, judges were being disciplined by the Superior Council of the Magistrates, which was led by the president and his Justice Minister. In other words, judges were being disciplined by an institution led by politicians. This does not augur well for transparency. Based on provisions from the initial constitutions, I conclude that the Beninese Constitution offers more protection and guarantees for its judges compared to the other countries' constitutions. From the analysis of the three indicators used in my discussions of this chapter including the comparative study of the three constitutional 
courts jurisprudence presented above, I conclude that the Constitutional Court in Benin with a dynamic and more aggressive judicial demeanor is more effective and efficient in protecting the constitution against politically motivated amendments compared to the other courts in Burkina and Senegal. 


\section{Chapter VII: The implications of non-consolidating amendments in Francophone Africa}

\section{Introduction}

The 1990s' waves of democratization brought great hope for positive political change in Africa. Many African countries experienced transition periods marked by the adoption of new constitutions. Two decades after the waves of democratization, there is "a new reverse wave" (Huntington, 1997), a retreat, and a negative trend of democratic practices (Diamond \& Plattner, 2010). This dissertation has shown that one of the most vivid signs of the retreat of democracy in Africa is the phenomenon of non-consolidating constitutional amendments. Non-consolidating amendments are not intended to consolidate neither democracy nor the rule of law. Instead, they are designed to reinforce and perpetuate the reign of incumbent power holders.

In this chapter, I conclude with a review of my work. After summarizing the main findings, I argue, based on the general context of governance in democratizing countries described above, that the findings are generalizable beyond the three cases used in my study. I conclude the chapter by mentioning some limitations of the dissertation.

\section{Summary of findings}

In the introduction of my work, I set out to answer a two-fold question: why are there so many constitutional amendments in newly democratizing Francophone West African countries and what facilitates this phenomenon? Before I answered the question, I explained that I am not just interested in the reasons for non-consolidating amendments' 
occurrence in democratizing countries. I am specifically interested in analyzing one particular type of amendment; the amendments that are not intended to advance democracy or the rule of law, but are rather, solely designed to help one individual or a group of individuals hold on to power by manipulating the constitution and electoral laws in their favor. These are the kind of laws that I refer to as non-consolidating amendments.

In chapter 3, I showed how to identify them using five indicators. The first one is the general context of governance. This indicator is important as it consists of describing the state of democracy in a given country. Once the state of governance is known it can be contrasted with the fundamental principles that any country claiming to be a constitutional democracy should obey. These principles (that I enumerated in chapter 3) require free and fair elections held in a timely fashion, a commitment to constitutionalism by all parties in the democratic game, the separation and balance of powers, and the renouncement to the use of informal rules such as clientelism in the conduct of government business. Any country where these basic principles are not respected is a potential victim of non-consolidating constitutional amendments, and democratizing countries, due to their fragile political context are, in general, vulnerable to nonconsolidating amendments. The other indicators of non-consolidating amendments are as follows: the specific context in which the amendment is made; the motivation for the amendment, the constitutional democratic principle (the principle in violation) that the amendment can be tested against, and the non-consolidating aspect of the amendment. After I identified six constitutional amendments in Burkina Faso and fifteen in Senegal, I evaluated them following the process I just described and I found three (50\%) nonconsolidating amendments in Burkina Faso and 10 (67\%) in Senegal. 
The importance of these findings is that I am able to shed light on a phenomenon neglected or not well-known in the democratic consolidation literature. My work shows that non-consolidating aspects of constitutional amendments are not always obvious to outsides observers of politics in a given country. Scholars such as Huntington (1991) emphasized the electoral process for the consolidation of democracy in democratizing countries. While this is obviously an important part of constitutional democracy, I showed that free, fair and timely held elections do not suffice to produce democratic consolidation in countries with fragile and weak democratic culture. As a matter of fact, the debate about democratic consolidation often misses the sophisticated nonconsolidating practices that prevent democratizing countries from reaching the level of consolidated democracies.

One of these practices is the uneven playing field (the incumbent power holder control of state resources, the media, and the legal system). By engaging in this type of non-consolidating behavior between elections, an incumbent power holder does not need to resort to electoral fraud to win elections (Levitsky \& Way, 2010). Although $81 \%$ of Africans would like to see incumbents removed, as Diamond (2010) suggests, incumbents in Africa are almost always sure to be reelected to continue their single partylike governance against democratic consolidation. I argued that although alternation in power is not a recipe for democratic consolidation in countries long ruled by authoritarian regimes, change can stimulate a new beginning of practice of the rule of law. The tremendous advantages of incumbent power holders, the executive hegemony, and the politics of clientelism prevent such democratic consolidation from happening. Actually, non-consolidating constitutional amendments constitute a legal manifestation of the 
practice of the uneven playing field, as the incumbent power holders who control the law often use it to advance their personal political agenda. Why does this phenomenon exist in the first place, and why is it prevalent in democratizing countries?

I have designed three possible explanations as a response to this question: the openness of the constitution-making process, the mechanism of constitutional amendment, and the independence of the constitutional courts. The openness of the constitution-making process is a path dependency argument in which I argued that the constitution-making process determines the quality of the constitutional document that comes out of it. I hypothesized that an open, transparent, and inclusive constitutional adoption process would lead to fewer non-consolidating amendments, as a consensual process has the potential of producing a constitutional document that would be owned, accepted, and defended by the parties involved.

As a matter of fact, my findings confirm this view. Comparing Benin, Burkina Faso and Senegal, I find that the more consensual and transparent the constitutionmaking process is, the less politically motivated amendments a country experiences. Benin has experienced no constitutional amendment since 1990, while Burkina Faso has experienced six amendments with a constitution-making process a little more transparent than the Senegalese. Senegal experienced fifteen amendments since 2001. In Burkina Faso, the process, although it was not as transparent as the one in Benin, was relatively more transparent than the Senegalese as the opposition was selectively ${ }^{103}$ implicated in

\footnotetext{
${ }^{103}$ I am using the word selectively to emphasize the fact that the political parties that took part in the Burkinabe constitution-making process did so based on invitations from the ruling party. In other words, it was not every organization that was welcome (Ye, 1995, p. 34).
} 
the constitution-making process. In Senegal, five experts drafted the constitution and the document was later submitted to the opposition for comments.

I have shown in chapter 4, that one of the major reasons the Beninese constitution has not experienced any amendment since its adoption in 1990, had to do with the transparency and consensus experienced in the constitution-making process (Badet, 2009). In my work, I showed as Elster (1993) argues, that a constitution-making process controlled by a sitting regime is more likely to produce less positive results compared to one done independently as the old regime is often part of the problem that the new constitution is seeking to fix. This was the particular merit of the Beninese national sovereign conference, i.e., it ignored advice from President Kérékou in order to freely create strong democratic institutions.

Moreover, the constitution-adoption process itself, because of its perceived consensus by the Beninese people, has been raised to the level of constitutional principle by the Constitutional Court in its 2006 decision against the overstaying of MPs' mandate. The court set a precedent by suggesting that any constitutional amendment should respect the consensual spirit of the 1990 sovereign conference. This offered a strong shield against future undue amendments to the Beninese Constitution. Such a shield exists neither in Burkina Faso, nor in Senegal where citizens did not feel strong ownership of their respective constitutions. Examples cited in chapter 3 show individual Beninese citizens who offered money, cars, computers, and other personal services to prevent their constitution from being modified. In 1997, the Burkinabe National Assembly successfully amended Article 37 of the constitution to allow an open-ended presidency for President Compaoré without any similar public outcry, although a vast majority of the 
Burkinabe people (according to Afro-barometer ${ }^{104}$ ) opposed the amendment of Article 37. In Senegal, President Wade, more than any of his predecessors, manipulated the constitution for personal political gains without major hurdles until 2012.

Compared to my other two variables, I argue that the openness of the constitutionmaking process has a stronger explanatory power. As a reminder, I suggested that the way a constitution is made (its openness, inclusiveness, and transparency) determines the value and the success of the document that comes out of it. The idea is that the strength of the democratic institutions such as the National Assembly, the presidency, the judiciary and the rules that regulate their internal functioning, depend on the success of the new constitution. The freer the constitution-making body is, the more likely it will be to create strong institutions that are able to protect the constitution.

In Benin, the national conference was able to engineer a constitutional amendment process that has a higher majority requirement than the Burkinabe and the Senegalese due to the will of the original drafters to make the fundamental document secured from easy and trivial amendments. In Benin, the final process for a constitutional amendment requires $80 \%$ approval of MPs. But before that final step, there is another requirement of $75 \%$ MPs approval to examine ${ }^{105}$ for any draft or proposal of amendment. These requirements are lower in the other two countries and I have shown, in chapter V how they have made a difference when it comes to protecting the constitution against politically motivated amendments.

\footnotetext{
104 Afrobarometer Rond 5 conducted From 2011-2012 (http://www.afrobarometer.org)

105 The difference between the final approval and the simple reception of a draft or proposal has been explained in chapter V, p.139. The difference between a draft and a proposal has also been clarified in the same chapter.
} 
In chapter VI, I showed that the Beninese Constitutional Court have been given more constitutional powers than its peer institutions in Burkina and Senegal. For instance, the institution was created as a full and independent institution separated from the rest of the judiciary, which was not the case in Burkina Faso and Senegal. The salaries of the Beninese Justices were set by a constitutional provision that put them on the same rank as government ministers. I explained how important such a provision is for the independence of the Beninese Constitutional Court vis-à-vis the executive. I also used several court cases challenging the executive power in Benin to show the independence of the court compared to the courts in Burkina and Senegal.

The mechanism of constitutional amendment (which is my second independent variable) and the independence of the constitutional court (my third variable), are created by constitutional provisions. The strength of these institutions, therefore, depends on the strength of the constitution, which in turn, derives its power from the process that brings it to life. If the internal decision-making of the constitutional drafting is viewed as undemocratic, the resulting document would necessarily lose democratic legitimacy, a key element for the legitimacy of all institutions deriving their power from the constitution. This can be better explained using an example: when in 2006, the constitutional court voided the first successful constitutional amendment in Benin, it did so based on the national consensus that created the 1990 constitution. In other words, the court was referring to the consensual Beninese constitution-making process that it presented as a principle of constitutional value ${ }^{106}$ Although, the court was the institution that ultimately stopped the non-consolidating amendment of 2006, it was helped by the

\footnotetext{
${ }^{106}$ See arguments presented in the court's decision in chapter 3.
} 
national constitution-making context. Even with a high majority requirement that was supposed to prevent any unnecessary or politically motivated amendment, the Beninese National Assembly gathered enough support to amend the constitution for MPs to overstay their initial mandate. This, however, does not suggest that the rigidity of the amendment process is inefficient in protecting against undue amendments. Constitutional rigidity does positively affect the occurrence of non-consolidating amendments as it significantly reduces the amendment rate.

I used the mechanism of constitutional amendment as my second research question to make sense of the phenomenon of non-consolidation constitutional amendment. I argued that a rigid constitution would lead to fewer undue constitutional changes. Rigid constitutions are defined in opposition to flexible constitutions that use ordinary legislative process. ${ }^{107}$ The degree of rigidity depends on the strategy of amendment used (Lutz, 1994). In other words, constitutions with strong procedural constraints would experience fewer politically motivated amendments. My findings support this view. I showed in Chapter 5 that a requirement for a high majority for constitutional amendment correlates with a low number of non-consolidating constitutional amendments. In Benin, I observed that the qualified majority for any constitutional amendment is $80 \%$ approval from the National Assembly members. The country has experienced no constitutional amendment since the adoption of its constitution in 1990. In Burkina Faso, the required majority for a constitutional amendment is $75 \%$. Six amendments of which three are non-consolidating were experienced in that country. Sixty percent is the qualified majority in Senegal, the

${ }^{107}$ New Zealand is an example of countries with flexible constitutional amendment process 
country with the youngest constitution (2001) among my case study countries, and yet a country with the highest number of amendments (fifteen in 2012). What makes these findings interesting is that all my three study countries have similar amendment processes and the same number of steps for any amendment (two steps), with the only major difference being the required majority. In other words, making the constitutional amendment process harder does matter in preventing undue amendments.

The third research question I used for the analysis of non-consolidating amendments in West Africa, is the independence of constitutional courts. My working hypothesis was that the more independent a constitutional court is, the better equipped and the more efficiently it can prevent politically motivated constitutional amendments. I defined the independence of constitutional courts using three indicators: the process of judges' selection, their term in office and the way they are removed from office. My comparative analysis of Benin, Burkina Faso and Senegal led me to conclude that because of its initial constitutional powers such as its original jurisdiction, its freedom to choose the chief justice, and the right for ordinary citizens to call upon the court, the Beninese Constitutional Court is not only more dynamic, but it is also more independent than its counterparts in Burkina Faso and Senegal. While in Senegal, the president is given power to nominate all constitutional council members, in Burkina Faso the president shares that responsibility with the parliament. However, because the parliament in that country is always led by the ruling party (since 1992, see appendixes 3-7), all the constitutional council members end up being nominated by the same ruling party. In Benin, the nomination process is shared by the president and the parliament. Unlike in Burkina Faso where the president shares the nomination power of judges with the 
president of the National Assembly, in Benin, the process is made more deliberative as the president of the National Assembly is not the only individual MP to nominate judges. While in Benin, the salary of constitutional court judges is set through a constitutional provision, in Senegal and Burkina Faso the issue is addressed through an organic law. Similar patterns exist when it comes to the protection of judges and their removal from office. In Benin where the constitutional court is an entire institution separated from the rest of the judiciary, judges have constitutional protection against any law suits or any illegal removal from office, which is not the case in the other two countries where the initial constitutional councils were part of the judiciary. Examples of the dynamism and activism ${ }^{108}$ of the Beninese court given in chapter 6 and the court docket confirm that the court is a big and serious player in the institutional landscape of the country.

I showed in chapter 6, that the Burkinabe and the Senegalese constitutional councils used judicial techniques to avoid giving opinions on tough cases involving the government or the president, due to their lack of independence. The techniques consist of the court declaring itself incompetent to decide certain cases. For example, in 2003, the Senegalese opposition reached out to the constitutional council for a decision on the creation of the CRAES. The argument was that the ruling party waited for the opposition MPs to leave the National Assembly then fraudulently passed a law on the creation of this important institution in their absence. The Senegalese Constitutional Council responded that it was incompetent to decide the case. This is what Fall (2011) calls the lack of audacity from the Senegalese Constitutional Council whose members don't

\footnotetext{
${ }^{108}$ It is the court decision that ended polygamy in the country. It is also the court that prevented the 2006 non-consolidating amendment that would have allowed MPs to overstay their mandate
} 
practice what is known in France as le devoir d'ingratitude (the duty of betrayal). The expression is used to refer to individual judges who decide against their nominating authority in order to show their independence. In Burkina Faso and Senegal, when the court does not declare itself incompetent, it usually decides in favor of the ruling party. This was the case when President Compaoré and President Wade were challenged regarding their right for reelection after completing their second terms. Both presidents were declared eligible by their respective constitutional councils and were allowed to run for a third mandate in Burkina Faso and Senegal. Actually, the Burkinabe and Senegalese councils are less active than the Beninese court due, in part, to their lack of original jurisdiction.

My analysis supports the claim that the more independent a court is, the better it can fight against undue constitutional amendments. Actually, because the Beninese court is more independent than the other courts in my case study, it was able to protect the constitution against politically motivated amendments. Constitutional justices in Benin showed some degree of audacity and independence by behaving as protectors of the constitution, which is needed in democratizing countries with fragile and weak democratic culture (Fall, 2011). In my work, I argued that due to the hegemony of presidential and semi-presidential regimes in my study countries, an activist constitutional court would be welcome in order to protect basic constitutional principles such as the balances and separation of powers, free and fair elections, the respect for constitutional mandates by government officials, etc. My findings show that this is a reality only in Benin where the court dares to challenge Congress and the executive power. 
In conclusion, the findings support my three claims that an open constitutionmaking process provides a shield against politically motivated amendments; that a difficult amendment process leads to fewer non-consolidating amendments and that a vibrant and independent constitutional court can efficiently protect a country against amendments aimed at individual political gains. None of these three factors taken alone, however, can prevent non-consolidating constitutional amendments. The openness (transparency and inclusiveness) can provide an opportunity for a better constitutional document endowed with the necessary legitimacy. It can create an opportunity for stronger democratic institutions; for the ultimate goal of preventing politically motivated amendments, however, this is not enough. My study has shown that in the case of Benin where the process was viewed as fair and legitimate, there still was a successful nonconsolidating amendment that actually passed the test of the high requirement majority for amendment (80\%). It was only stopped thanks to the Beninese Constitutional Court.

This not only suggests that rigidity of the amendment process as a factor in fighting against undue amendments has some limitations, but it also suggests that the amendment process could be made more difficult by using a combination of techniques such as the intervening legislature (double vote), ${ }^{109}$ the legislative complexity (use of referendums) or other devices ${ }^{110}$ mentioned in Lutz (1994) and that I have discussed earlier in my literature review section. The effect of a constitution that is made too easy to amend is the incentive given to politicians to use the fundamental law for their personal political agenda. Examples were given in chapter 3, where I explained that the

\footnotetext{
${ }^{109}$ Article 168 of the 1978 Spanish Constitution is a good illustration of what I am referring to.

${ }^{110}$ Article 290 of the 1992 Ghanaian Constitution is another illustration of the types of difficulties that can be used to slow or prevent unnecessary amendments.
} 
Senegalese leaders used their constitution not only to remove their opponents from power, but also for retaliation. Making a constitution hard to amend, however, is not necessarily a good thing (Lutz, 1994). It only seems to be the best thing to do in the particular context of weak democratic culture that prevails in democratizing countries. I argue that in such context, the negative effects outweigh the benefit of having an easy to amend constitution, mainly because an easy to amend constitution creates a permanent situation of non-consolidating constitutional democracy. Politicians can use the constitution to discriminate against their opponents. I have cited in the introduction the case of Allassane Dramane Ouattara who was prevented from taking part in the 2000 Ivoirian presidential election due to a constitutional amendment (Article 35). Later, there was a rebellion in the country that cost lives of many Ivoirians. One negative impact of easy constitutional amendments in a country is the environment of uncertainty that it helps create due to the fact that the rules of the democratic games are often modified and skewed toward the ruling party. A ruling party can use the law to starve the opposition by punishing businessmen who support their opponents. An easy amendment process is a receipt for any type of constitutional abuses from political leaders who are more concerned about the consolidation of their grip on power than the consolidation of democracy in their country.

The findings make the point that my three independent variables (openness of constitution-making, rigidity of amendment process, and the independence of the constitutional court) have a negative effect on the consolidation of democracy in Senegal and Burkina Faso, but not in Benin. As a reminder, my general theory is that in countries where all the three variables are positive, there should not be any non-consolidating 
constitutional amendment. In other words, if the constitution-making process is inclusive, transparent and consensual and if the constitution is difficult to amend, and if the constitutional court is independent with activist judges willing to defend the constitution, then there should not be any non-consolidating constitutional amendments. My finding showed that this happened in Benin only. In Burkina Faso and Senegal where the conditions mentioned above were not fulfilled, basic democratic principles such as the balance and separation of powers, the respect for constitutional mandates, the commitment to judicial independence, and the commitment to abide by democratic rules instead of informal rules of clientelism etc. were frequently violated. Consequently, Burkina Faso and Senegal experienced high level of non-consolidating constitutional amendments (three and ten, respectively), whereas Benin experienced none.

\section{Generalization of findings}

In this dissertation I did a qualitative study using data from three Francophone West African countries. The findings support the claims that non-consolidating constitutional amendments are mainly done for the conservation of power. Moreover, I made the point that the occurrence of non-consolidating constitutional amendments slow down or prevent democratizing countries from moving toward the consolidation of constitutional democracy. I demonstrated that non-consolidating constitutional amendments as a political disease can be cured, since we now know why the phenomenon exists and what can be done to stop it. More importantly, we know that nonconsolidating amendment as a political phenomenon happens in countries with specific characteristics of governance. In other words, it does not happen only in Benin, Burkina Faso, and Senegal. We know from chapter 3, that non-consolidating amendments 
constitute a common political disease for all countries that share certain characteristics of poor governance such as the practices of informal rules of clientelism, the prevalence of an uneven playing field in the practice of the democratic game, the creation of a political environment with an hegemonic executive power and a dominant ruling party that has no respect for the constitutional right of the opposition or the civil society. Nonconsolidating amendments flourish in the type of regimes with immeasurable incumbency advantages. The difference between countries that meet the above criteria and those considered consolidated democracies is that the former show signs of instability.

While my work is based on research done in three countries, it can safely be generalized to all countries with similar characteristics. In other word, any country showing signs of the political instability mentioned above are potential candidates for non-consolidating constitutional amendments. Politicians are often obsessed with power and any country where the rules of the democratic game are not well set or respected can easily contract this political disease called non-consolidating constitutional amendments. I argue that the three solutions against the phenomenon that are part of my findings can also be applied to any country that experiences non-consolidating amendments. I am referring to my claims that an open constitution-making process provides a shield against politically motivated amendments; and that a difficult amendment process lead to fewer non-consolidating amendments and that a vibrant and independent constitutional court can efficiently protect a country against amendments aimed at individual political gains.

\section{Extending the Dissertation}


My findings have shown that there is no single factor that can account for the occurrence of non-consolidating constitutional amendments in democratizing countries. I have explained how two factors were combined in the Beninese 2006 Constitutional Court decision that prevented the first successful politically motivated amendment in the country. In my explanation of how the court voided the amendment for the overstaying of MPs' mandate, I mentioned the role of civil society organizations. I showed that the Beninese civil society created a movement called Hands off my Constitution to fight against any undue amendment (Adjovi, 2006; Banégas, 1995). This suggests that civil society is a stakeholder when it comes to the conduct of public affairs in a given country. It can be an important variable to consider when studying factors that can help prevent the phenomenon of non-consolidating constitutional amendments. In democratic regimes, civil society organizations can play the role of watchdog due to their ability to constrain politicians in matters of policy change. My work could consequently be extended to include civil society as an entire variable that could be studied in order to see the degree of influence this component has on the fight against unwise amendments.

In the introduction to this dissertation, I mentioned the important influence of France on its formers colonies (Reynjens, 1991; Clark, 1997). I also suggested that the multilateral partners such as the IMF and the World Bank can influence politics in developing countries. Aid has been used by developed countries (bilateral and multilateral partners) to influence governments around the world (Collier, 2007; Leather \& Foster, 2004; Eide \& Kracht, 2005; Drèze \& Sen, 1989; Barrett \& Maxwell, 2005). The point is that the international community can exercise greatly influence countries heavily reliant on foreign aid (Akiba, 2004; Akindele, 2003). Therefore, the influence of 
the international community is an important factor that can be used as a variable, as a strong opposition of the international community to a particular constitutional amendment can deter political leaders from moving forward with it, either because of the reputation cost they might face, or simply because they heavily rely on foreign aid. Future research can investigate these two factors using the analysis developed in this dissertation, for better results on how to fight against non-consolidating constitutional amendments for the advancement of democracy and the rule of law in democratizing countries.

\section{Conclusion}

This dissertation has investigated the phenomenon of non-consolidating constitutional amendments in Francophone West Africa. I demonstrated that the phenomenon constitutes a retreat of democratic consolidation in democratizing countries due to the negatives effects it has on the rule of law. The comparative study of three countries allowed me to show that an important factor for the consolidation of democracy in a given country has to do with the initial process of constitution-making, because that process lays down the foundation for a country future democratic life. Such a process has to be viewed and accepted by all stakeholders as legitimate. This is a difficult task for many countries as the drafting of new constitutions often happens under less than ideal or difficult political, economic or social conditions (Elster, 1993). I showed that the initial process, when done properly (if it is inclusive and transparent) can provide a country with strong institutions such as a strong (independent) constitutional court and a strong parliament well-designed to preserve the democratic principles of separation of powers. This is important because the mechanism of constitutional amendment and the 
constitutional court as institutions are all created through constitutional provisions. Institutions created by the constitutions and that derive their just powers from the fundamental law cannot be strong or legitimate if the constitution that creates them is viewed as weak or illegitimate. This, led me to argue that the openness of constitutional amendment as a factor has a broad explanatory power that includes my other two variables. A combination of the three factors discussed in this dissertation is, however, necessary for a successful fight against corrupt amendments. I argue that it is not a bad idea to have activist constitutional judges in democratizing countries, because they can efficiently fight against politically motivated changes to the fundamental law. Besides constitutional powers, constitutional court judges need some audacity to protect basic democratic principles in country where democratic practices are not well-embodied in the daily life of politicians who are often inclined to use informal rules to skew the democratic game in their favor. 


\section{Appendices}

Appendix 1: Votes on constitutional amendments in Burkina Faso

\begin{tabular}{|l|l|l|l|l|l|l|}
\hline Amendments & Voters & Yes & No & Abstention & Absents & Total \\
\hline $\begin{array}{l}\text { 002/97/ADP } \\
\text { du 27 janvier } \\
1997\end{array}$ & 106 & 87 & 14 & 05 & 01 & 107 \\
\hline $\begin{array}{l}\text { 003- } \\
\begin{array}{l}2000 / A N ~ d u \\
11 \text { avril 2000 }\end{array}\end{array}$ & 97 & 97 & 00 & 00 & 14 & 111 \\
\hline $\begin{array}{l}\text { 001- } \\
\begin{array}{l}2002 / A N \\
\text { du 22 } \\
\text { janvier 2002 }\end{array}\end{array}$ & 108 & 108 & 00 & 00 & 03 & 111 \\
\hline $\begin{array}{l}015- \\
2009 / A N ~ d u \\
30 \text { avril 2009 }\end{array}$ & 103 & 96 & 06 & 01 & 08 & 111 \\
\hline $\begin{array}{l}\text { 023- } \\
\begin{array}{l}2012 / A N ~ d u \\
18 \text { mai 2012 }\end{array}\end{array}$ & 107 & 104 & 01 & 02 & 04 & 111 \\
\hline $\begin{array}{l}\text { 033- } \\
2012 / A N ~ d u \\
11 \text { juin 2012 }\end{array}$ & 94 & 88 & 06 & 00 & 17 & 111 \\
\hline
\end{tabular}

Source: Registre des délibérations de l'Assemblée Nationale

Appendix 2: Burkina Faso Constitutional Council opinions and decisions from 19912008

\begin{tabular}{|l|l|l|}
\hline \multicolumn{2}{|l|}{ Opinions } & 426 \\
\hline \multirow{2}{*}{ Decisions } & Control of constitutionality & 24 \\
\cline { 2 - 3 } & Electoral decisions & 40 \\
\hline
\end{tabular}

Adapted from Centre pour la Gouvernance Démocratique, CGD (2009, p. 135)

Appendix 3 : First Legislature of Burkina Faso (1992-1997)

\begin{tabular}{|l|l|}
\hline Party & Seats \\
\hline ODP/MT & 78 \\
\hline CNPP/PSD & 12 \\
\hline RDA & 06 \\
\hline ADF & 04 \\
\hline
\end{tabular}




\begin{tabular}{|l|l|}
\hline PAI & 02 \\
\hline MDP & 01 \\
\hline MDS & 01 \\
\hline PSB & 01 \\
\hline RSI & 01 \\
\hline UDS & 01 \\
\hline
\end{tabular}

Appendix 4: Second Legislature of Burkina Faso (1997-2002)

\begin{tabular}{|l|l|}
\hline Party & Seats \\
\hline CDP & 102 \\
\hline PDP & 05 \\
\hline UDF/RDA & 02 \\
\hline ADF/RDA & 01 \\
\hline CDF & 01 \\
\hline
\end{tabular}

Appendix 5: Third Legislature of Burkina Faso (2002-2007)

\begin{tabular}{|l|l|}
\hline Party & Seats \\
\hline CDP & 57 \\
\hline ADF/RDA & 13 \\
\hline PDP/PS & 10 \\
\hline UNDD & 06 \\
\hline UPR & 06 \\
\hline PAI & 05 \\
\hline UNIR/MS & 03 \\
\hline PCP & 03 \\
\hline PDS & 02 \\
\hline PAREN & 01 \\
\hline CNDP & 01 \\
\hline CPS & 01 \\
\hline CDS & 01 \\
\hline CDF & 01 \\
\hline UPD & 01 \\
\hline FDS & 01 \\
\hline RDEB & 01 \\
\hline RDF & 01 \\
\hline
\end{tabular}

Appendix 6: Fourth Legislature of Burkina Faso (2007-2012)

\begin{tabular}{|l|l|}
\hline Party & Seats \\
\hline CDP & 73 \\
\hline ADF/RDA & 14 \\
\hline PAI & 01 \\
\hline UPR & 05 \\
\hline UNIR/MS & 05 \\
\hline
\end{tabular}




\begin{tabular}{|l|l|}
\hline FASO METBA & 01 \\
\hline PDS & 02 \\
\hline RPC & 01 \\
\hline RDS & 01 \\
\hline UDPS & 01 \\
\hline FFS & 01 \\
\hline CFDB & 03 \\
\hline RDB & 02 \\
\hline PARENT & 01 \\
\hline
\end{tabular}

Appendix 7: Fifth Legislature of Burkina Faso

\begin{tabular}{|l|l|}
\hline Party & Seats \\
\hline CDP & 70 \\
\hline UPC & 19 \\
\hline ADF/RDA & 18 \\
\hline UPR & 05 \\
\hline UNIR/MS & 04 \\
\hline CFD-B & 03 \\
\hline PDS Metba & 02 \\
\hline CNPB & 01 \\
\hline Le Faso autrement & 01 \\
\hline RDS & 01 \\
\hline RDB & 01 \\
\hline ODT & 01 \\
\hline UNDD & 01 \\
\hline
\end{tabular}

Appendix 8: First legislature of Senegal (2001-2005)

\begin{tabular}{|l|l|}
\hline Party & Seats \\
\hline Coalition Sopi & 89 \\
\hline AFP & 11 \\
\hline PS & 10 \\
\hline URD & 3 \\
\hline AJ-PADS & 2 \\
\hline PIT & 1 \\
\hline PLS & 1 \\
\hline PPC & 1 \\
\hline APJ/JJ & 1 \\
\hline RND & 1 \\
\hline
\end{tabular}


Appendix 9: Second Legislature of Senegal (2007-2012)

\begin{tabular}{|l|l|l|l|}
\hline Party & Total Seats & Plurality & proportional \\
\hline Coalition Sopi 2007 & 131 & 90 & 41 \\
\hline $\begin{array}{l}\text { Coalition Takku } \\
\text { Défaraat }\end{array}$ & 3 & 0 & 3 \\
\hline $\begin{array}{l}\text { Coalition And } \\
\text { Defar }\end{array}$ & 3 & 0 & 3 \\
\hline Coalition Waar Wi & 3 & 0 & 3 \\
\hline RP & 2 & 0 & 2 \\
\hline $\begin{array}{l}\text { Parti socialiste } \\
\text { authentique }\end{array}$ & 1 & 0 & 1 \\
\hline CRC & 1 & 0 & 1 \\
\hline UNP & 1 & 0 & 1 \\
\hline Alliance Jëf Jël & 1 & 0 & 1 \\
\hline RES & 1 & 0 & 1 \\
\hline MRDS & 1 & 0 & 1 \\
\hline FSD-BJ & 1 & 0 & 1 \\
\hline PSD - Jant bi & 1 & 0 & 1 \\
\hline S : Pall| & & & \\
\hline
\end{tabular}

Source : Parline : http://www.ipu.org/parline-f/reports/arc/1277_07.htm 


\section{References}

Abutudu, M. (2009). A Critical Assessment of the Constitutionalism Landscape in West Africa. The Western Journal of Black Studies, 33(2), 132-139.

Adamon, A. D. (1994). le Renouveau democratique au Benin: La confernce nationale des foces vives et la periode de transition. Paris: L'Harmattan.

Adamon, A. D. (1995). Le Renouveau democratique au Benin: les elections de la periode de transition. Paris: l'Harmattan.

Adams, W. P. (1980). The first American constitutions. Chapel Hill: University of North Carolina Press.

Adjovi, V. E. (2003). Liberté de presse et affairisme médiatique au Bénin. Politique Africaine, 157-172.

Adjovi, V. E. (2006). Mobilisation citoyenne et demonopolisation du travail politique au Benin. Perspective Afrique, 187-223.

Akiba, O. (2004). Constitutionalism and Society in Africa. Burlington: Ashgate Publishing Company.

Akindele, R. A. (2003). Civil Society, Good Governance and the Challenge of Regional Security in West Africa. Lagos: African Strategic and Peace Research Group.

Anckar, D., \& Karvonen, L. (2002). Constitutional Amendment Methods in the Democracies of the World. Nordic Political Science Congress. Aalborg: URL: Http://www.socsci.auc.dk/institut2/nopsa/arbejdsgruppe24/anckarkarvonen.pdf.

Arthur, G. (2004). Predatory versus Developmental Rule in Africa. Democratization, 11(3), 88-110. 
Badet, G. (2009, 12 12). Gilles Badet blog:www.La-constitution-en-afrique.Org. Retrieved from La Constitution en Afrique: http://www.la-constitution-enafrique.org/article-la-constitution-a-19-ans-41028114.html

Barkan, J. D. (2010). Legislatures on the Rise. In L. Diamond, \& M. F. Plattner, Democratization in Africa: Progress and Rereat (pp. 33-46). Baltimore: The Johns Hopkins University Press.

Batler, D., \& Ranney, A. (1978). 'Summing Up' in David Butler and Austin Ranney. In D. B. Ranney, Referendums: A comparative Study of Practice and Theory (p. P. 221). Washington DC: American Enterprise Institute.

Bayart, J.-F. (1989). L'Etat en Afrique, La politique du ventre. Paris: Fayard.

Beetham, D. (1994). Conditions for Democratic Consolidation. Review of African Political Economy, 157-172.

Benégas, R. (1995). Mobilisation sociale et opposition sous Kérékou. Politique Africaine, $25-42$.

Beyme, K. V. (1988). The Genesis of Consitutional Review in Parliamentary System. In C. Landfried, Constitutional Review and Legislation: an International Comparison (pp. 21-38). Baden- Baden: Nomos Verlangsgesellschaft.

Bhattarai, H. P., \& Subedi, J. (2007). Democratic Constitution Making: Experience from Nepal, Kenya, South Africa and Sri Lanka. Kathmandu: Nepal South Asia Center.

Biggs, F. (2001). Participation in Constitution-making. In G. Hyden, \& D. Venter, Constitution-Making and Democratisation in Africa (pp. 177-182). Pretoria: MC Printer. 
Bolle, S. (2005). Des Constiutitions" made in" Afrique. VIe Congres Francais de droit Constitutionel, Montpellier 9,10, et 11 Juin 2005 (pp. 1-24). Montpellier: Afrique. Retrieved April 02, 2012, from http://www.droitconstitutionnel.org/congresmtp/textes7/BOLLE.pdf

Bonime-Blanc, A. (1987). Spain's transition to democracy: the politics of constitutionmaking. Boulder: Westview Press.

Braithwaite, W. T. (1971). Who Judges the Judges? A Study of Procedures for Removal and Retirement . Chicago: American Bar Foundation.

Brant, I. (1972). Impeachment: Trials and Errors. New York: Alfred . A. Knopf. Bratton, M. (1999). Second Election in Africa. In L. Diamond, \& M. F. Plattner, Democratization in Africa (pp. 18-33). Baltimore: The Johns Hopkins University Press.

Bratton, M. (2010). Formal Versus Informal Institutions in Africa. In L. Diamond, \& M. F. Plattner, Democratization in Africa: Progress and Retreat (pp. 103-117). Baltimore: The Johns Hopkins University Press.

Bruce, V., \& Csanadi, M. (1993). Uncertainty in transition: Postcommunism in Hungary. . East European Politics and Societies, 240-276.

Buchanan, J. M., \& Tullock, G. (1962). The calculus of consent: Logical foundations of constitutional democracy. Ann Arbor: University of Michigan Press.

Buchanan, J., \& Tulloch, G. (1965). The Calculus of Consent: Logical Foundations of Constitutional Democracy. University of Michigan Press.

C.G.D. (2008). L'Alternance et les regles du jeu démocratique au Burkina. Ouagadougou: Centre pour la Gouvernance Démocratique. 
C.G.D. (2009). Avis et Décisions Commentés de la Justice Constitutionnelle Burkinabe de 1960 à nos Jours. Ouagadougou: Centre pour la Gouvernance Démocratique.

C.G.D. (2009, June). Le projet de révision de la constitution de juin 1991: une manoeuvre delosive? Ouagadougou: Centre pour la Gouvernance Démocratique.

Cabanis, A., \& Martin, L. M. (2005). Un Espace d'isomorphisme constitutionel. Paris: Dalloz.

Cabanis, A., \& Martin, M. L. (2010). Le Constitutionalisme de la Troisième Vague en Afrique Francophone. Bruxelles: Academia Bruylant.

Calabresi, S. G., \& Lindgreen, J. (2006). Term Limits for the Supreme Court: Life Tenure Reconsidered. Harvard Journal Of Law and Policy, 769-877.

Carothers, T. (1999). Think again: Civil society. Foreign Policy, 18-29.

Carrington, P. D., \& Cramton, R. C. (2005). The Supreme Court Renewal Act: A Return to Basic Principles. In P. D. Carrington, \& R. C. Cramton, Reforming the Court: Term limits for Supreme Court Justices (pp. 467-471). Durham: Carolina Academic Press.

Cheramy, B. (1976). Une Revision Constitutionnelle au Sénégal. Ethiopiques, 13-21.

Clark, J. F. (1997). Introduction. In J. F. Clark, \& D. E. Gardinier, Political Reform in Francophone Africa (p. 1). Colorado: Westview Press.

Cohen, A. (1990). A Deal Undone: The Making and Breaking of the Meech Lake Accord. Vancouver: Douglas \& McIntyre.

Conac, G. (1993). L'Afrique en transition vers le pluralisme politique. Paris: Economica. 
Congleton, R. D., \& Rasch, B. E. (2006). Amendment Procedures and Constitutional Stability. In R. D. Congleton, \& B. Swedenborg, Constitutional Design and Public Policy (pp. 319-342). Cambridge: The MiT Press.

Converse, P., Dahl, R., Fishlow, A., Gibbs, J. L., Inkeles, A., Schmitter, P. C., . . Thomaas, M. E. (1992). Democratization in African. Washington D.C.: National Academy Press.

Creevey, L., Ngomo, P., \& Vengroff, R. (2005, june 3). Party Politics and Different Paths to Democratic Transitions: A Comparison of Benin and Senegal. Retrieved from Sage: http://ppq.sagepub.com/

Cronin, T. E. (1989). Direct Democracy: The Politics of Initiative, Referendum, and Recall. Massachusetts: Harvard University Press.

Cross, F. (2008). Judicial independence. In R. D. Keith E. Whittington, The Oxford handbook of law and politics (pp. 558-575). New York: Oxford University Press.

Dahl, R. A. (1997). Development and Culture. In L. Diamond, M. F. Plattner, Y.-h. Chu, \& H.-m. Tien, Consolidaing the Third Waves Democracies (pp. 35-39). Baltimore: The Johns Hopkins University Press.

Diamond, L. (1999). Developing Democracy: Toward Consolidation. Baltimore: The Johns Hopkins University Press.

Diamond, L. (2010). The Rule of Law versus the Big Man. In L. Diamond, \& M. F. Plattner, Democratization in Africa: Progress and Retreat (pp. 47-58). Baltimore: The Johns Hopkins University Press.

Diamond, L., \& Plattner, M. F. (2010). Democratization in Africa: Progress and Retreat. Baltimore: The Johns Hopkins University Press. 
Diamond, L., Plattner, M. F., Chu, Y.-h., \& Tien, H.-m. (1997). Consolidating the Third Waves Democracies. Baltimore: The Johns Hopkins University Press.

Dicey, A. (1890). Ought Referendum to be Introduced Into England. Comtemporary Review, 502.

Diop, M. S. (2009). http://afrikibouge.com/droit/science-politique/888-article-dusenegalais-medoune-samba-diop. Retrieved from http://afrikibouge.com/component/jomcomment/trackback/888/com_content

Dossa, A. (2005, December 30). Financement de la Cena : Alcrer propose un guichet d'emprunt obligataire. Fraternité, p. N: 1503.

Ebeku, K. S. (2006). The Succession of Faure Gnassingbé to the Togolese Presidency: an international law perspective. Uppsala: The Nordic Africa Institute.

Ebrahim, H. (2001). The public Participation Process in South Africa. In H. Goran, \& V. Denis, Constitution-Making and Democratisation in Africa (pp. 153-161). Pretoria: MC Printer.

Ekeh, P. P. (2004). The Impact of Constitutionalism Thought in Africa. Constitutionalism and Society in Africa, 25-41.

Elster, J. (1993). Constitution-Making in Eastern Europe: Rebuilding the Boat in the Open Sea. Public Administration, 169-217.

Elster, J. (1995, November). Forces and Mechanisms in the Constitutions-Making Process. Duke Law Journal, 45(2), 364-396.

Elster, J. (2000). Ulysses Unbound: Studies in Rationality, Precommitment, and Constraints. Cambridge: Cambridge University Press.

Epstein, L., \& Jack, K. (1998). Choices Justices Make. Washington DC: CQ Press. 
Epstein, L., \& Knight, J. (2003). Constitutional borrowing and nonborrowing. Oxford University Press and New York University School of Law, 196-223.

Fafard, P., \& Reid, R. D. (1991). Constituent assemblies: a comparative survey. Kingston/ Ontario/ Canada: Institute of Intergovernment Relations.

Fall, I. M. (2007). Textes Constitutionnels du Sénégal de 1959 à 2007. Dakar: Credilla.

Fall, I. M. (2008). Le pouvoir Exécutif dans le Constitutionalisme des Etats d'Afrique. Paris: L'Harmattan.

Fall, I. M. (2008). les Decisions et Avis du Conseil Constitutionnel du Senegal. Dakar: Credila.

Fall, I. M. (2009). Evolution Constitutionnelle du Sénégal: de la veille de l'Indépendance aux élections de 2007. Dakar: Credilla.

Fall, I. M. (2011). Les révisons constitutionelles au Sénégal: Révisions consolidantes et révisions déconsolidantes de la démocratie sénégalaise. Dakar: Credilla.

Fall, I. M. (2012). Une démocratie "ancienne" en mal de réforme: Rapport sur l'état de la démocratie et de la participation au Sénégal. Dakar: Open Society Foundation.

Fall, I. M., Hounkpe, M., Jinadu, A., \& Pascal, K. (2011). Election management bodies in West Africa : a comparative study of the contribution of electoral commissions to the strenthening of democracy. Johannesburg: Open Society Foundations.

Farnsworth, W. (2006). The Case for Life Tenure. In R. C. Cramton, \& P. D. Carrington, Reforming the Court: Term Limits for Supreme Court Justices (pp. 251-270). Durham: Carolina Academic Press. 
Favoreu, L. (1988). The Constitutional Council and the Parliament in France. In C. Landfried, Constitutional Review and Legislation: an International Comparison (pp. 81-108). Baden-Baden: Nomos Verlagsgesllschaft.

Fayemi, k. (2001). Building a Regional Network for Constitutional-making: Prospects and Challenges in West Africa. In S. Jegede, A. Ale, \& E. Akinsola, State Reconstruction in West Africa (pp. 245-271). Lagos: Committee for the Defense of Human Rights.

Fayemi, K. (2003). Constitutionalism in Transition in Africa: Balance Sheet and Prognosis. In K. Fayemi, Deepening the Culture of Constitutionalism: Regional Constitutional Development in Africa (pp. 21-52). Lagos: Center for Democracy and Development.

Ferejohn, J. E. (1997). The politics of Imperfection: The Amendment of Constitutions. Law and Social Inquiry, 501-531.

Ferejohn, J. E. (2002). Constitutional Review in the Global Context. New York University Journal of Legislation and Public Policy, 40-59.

Ferreres-Comella, V. (2000). A Defense of Constitutional Rigidity. Colloquium on Constitutional Theory (pp. 1-24). New York : http://www.giuri.unige.it/intro/dipist/digita/filo/testi/analisi_2000/ferreres.pdf. Retrieved 12 04, 2012, from http://www.giuri.unige.it/intro/dipist/digita/filo/testi/analisi_2000/ferreres.pdf

Fiss, O. M. (1993). THe Limits Of Judicial Independence. University of Miami InterAmerican Law Review, 25(58), 57-76. 
Fomunyoh, C. (2001). Democratization in Fits and Starts. Journal of Democracy, 123, $37-50$.

Fondation Konrad Adenauer. (2009). Commentaire de la Constitution Beninoise du 11 Decembre 1990: Esprit, Lettre, interprétation et pratiques de la Constitution par le Benin et ses Institutions. Cotonou: COPEF.

Friedman, B. (2002). The History of Contermajoritarian difficulty, part II: Reconstruction's Political court. Georgetown Law Journal, 1-65.

Fuller, L. (1969). The Morality of Law; revised edition. New Haven: Yale University Press.

Garané, A. (1997, Octobre). L'acte II du processus démocratique au Burkina Faso: portée juridique et politique de la loi du 14 février 1997 portant révision de la Constitution. Revue burkinabè de droit(33), 33-59.

Ghai, Y. (2007). People take lead: Participatory Process of constitution Making in Kenya. In H. P. Bhattarai, \& J. Subeki, Democratic Constitution making: Experiences from Nepal, Kenya, South Africa and Sri Lanka (pp. 119-131). Kathmandu: Nepal South Asian Center.

Giovannoni, F. (2003). Amendments Rules in Constitutions. Public Choice, 115(1/2), 3761.

Goldstein, R. (1996). Patterns of Missing Data. Stata Technical Bulletin, 32, 12-13.

Good, K. (2003). Democracy and the Control of Elite. In H. Melber, Limits to Liberalization in Southern Africa (pp. 1-23). Cape Town: HSRC Press.

Gooding, R. E. (1996). The Theory of Institutional Design. Cambridge: Cambridge University Press. 
Grofman, B. (1986). Electoral Laws and their Political Consequences. New York: Agathon.

Guarnieri, C., \& Pederzoli, P. (2002). The Power of Judges: A Comparative Study of Courts and Democracy. Oxford: Oxford University Press.

Gyimah-Boadi, E. (1999). The Rebirth Of Africa Liberalism. In L. Diamond, \& M. F. Plattner, Democratization in Africa (pp. 34-47). Baltimore: The Johns Hopkins University Press.

Hammons, W. C. (1999). Was James Madison Wrong? Rethinking the American preference for short, framework-oriented constitutions. American Political Science Review, 837-849.

Hanna, L. (2011). Making Constitutions in Deeply divided societies. Cambridge: Cambidge University Press.

Hanssen, F. A. (1999). The effects of judicial instruction on uncertainty and the rate of litigation: The election versus appointment of states judges. Journal of Lagal Studies, 2005-232.

Haysom, N. (2007). Negotiating a Sustainable Political Settlement: Lessons from the South Africa transition. In B. H. P, \& S. Jhalak, Democratic Constitutions Making: Experiences from Nepal, Kenya, South Africa and Sri Lanka (pp. 105118). Kathmandu: Nepal South Asia Center.

Hesseling, G. (1996). La reception du droit constitutionnel en Afrique trente ans après: quoi de neuf? in Zoethout, C. M., Pietermaat-Kros, M. E., \& Akkermans, P. W. (1996). Constitutionalism in Africa: A quest for autochtonous principles.

Rotterdam: Sanders Institute. 
Hesseling, G. (2010). Le Sénat au Sénégal, une attraction secondaire ? Afrilex, 1-27.

Hirschl, R. (2004). Toward Juristocracy: The Origins and Consequenses of new Constitutionalism. Cambridge: Havard University Press.

Holmes, S., \& Sunstein, C. R. (1995). The politics of constitutional revision inEastern Europe. In L. Sanford, Responding to imperfection: The theory and practice of constitutional amendments (pp. 275-306). Princeton: Princeton University Press.

Huntington, S. P. (1991). The Third Wave: democratization in the late twentieth century. Norman: University of Oklahoma Press.

Huntington, S. P. (1997). Democracy for the Long Haul. In D. Larry, M. F. Plattner, Y.h. Chu, \& H.-m. Tien, Consolidating the Third Wave Democracies (pp. 3-13). Baltimore: The Johns Hopkins University Press.

Hyden, G. (2006). African Politics in Comparative Perspective. New York: Cambridge University press.

IDEA, I. (1998). La Democracie au Burkina Faso. Stockholm: IDEA.

Institut africain pour la démocratie. (1997). L'opposition dans les parlements africains: actes du Séminaire parlementaire régional sur "Rôle, droits et responsabilités de l'opposition dans les parlements africains". Ouagadougou: Démocraties africaines.

International IDEA. (1998). La Démocratie au Burkina Faso. Stockholm: Bröderna Carlssons Boktryckeri AB.

International IDEA. (2007). Partis politiques en Afrique de l'Ouest: le défis de la démocratisation dans les Etats fragiles . Stockholm: International IDEA. 
Joireman, S. F. (2001, December). Inherited Legal Systems and the Effective Rule of Law: Africa and the Colonial Legacy. Journal of Modern African Studies, 39(4), $571-596$.

Jones, A. K. (2008). Ethnic Parties Success in Latin America: A study of Campaing and Elections in Ecuador. Retrieved from ProQuest Dissertations and Theses, UMI $\mathrm{N}: 3340257$.

Kanté, B. (1989). « le Sénégal un exemple de continuité politique et d'instabilité. Constitutionnelle », . Revue juridique politique et economique du Maroc, 145160.

Kanté, B. (1996). Le Constitutionalisme à l'épreuve de la transition démocratique en Afrique. In Z. M. Carla, E. P.-K. Marlies, \& W. A. Piet, Constitutionalism in Africa: A Quest for Autochthonous Principles (pp. 17-32). Dêventer: Gouda Quint.

Karl, T. L. (1986). Imposing Consent: Electoralism and Democratization in El Salvador. In P. W. Drake, \& E. Silva, Election and Democratizationin Latin America: 19971985 (pp. 9-36). San Diego: University of California San Diego.

Keith, L. C. (2002). Judicial Independence and human rights protection around the world. Judicature, 85(4), 195-200.

Kobach, K. (1993). The Referendum: Direct Democracy in Switzerland. Dartmouth: Aldershot.

Kokoroko, D. (2009, 11 11). Les élections disputées : réussites et échecs. Pouvoirs, 115125. Retrieved from www.revue-pouvoirs.fr: http://www.revue-pouvoirs.fr/Leselections-disputees-reussites.html 
Korenica, F., \& Doli, D. (2011). Constitutional Rigidity in Kosovo: Significance, Outcomes, And Rationale. International Law Review: Online Companion, 2(6), 129.

Kurland, P. B. (1969). The Constitution and the Tenure of Federal Judges: Some Notes from History. The University of Chicago Law Review, 665-698.

Landfried, C. (1988). Constitutional Review and Legislation. Baden: Nomos Verlagsgesellschaft.

Lane, J.-E. (1996). Constitutions and Political Theory. Manchester: Manchester University Press.

Larkins, C. M. (1996). Judicial Independence and Democratization: a theory and Conceptual analysis. American Journal of Comparative Law(44), 605-626.

Lawoti, M. (2007). Constitution as Sources of Exclusion: An Overview of the 1990 Constitution. In H. P. Bhattarai, \& J. Subedi, Democratic Constitution Making: Experiences from Nepal, South Africa and Sri Lanka (pp. 11-50). Kathmandu: Nepal South Asian Center.

LeVan, A. C. (2011). Power Sharing and Inclusive Politics in Africa's Uncertain Democracies. Governance, 31-53.

Levitsky, S., \& Way, L. A. (2010). Why Democracy Needs a Level Playing Field. Journal of Democracy, 57-68.

Lida, K. (1998). Stategic Acrors or Passive Reactors? The Political Economy of U.S. Japanese Monetary Relations. In R. M. Siverson, Strategic Politicians, Institutions and Foreign Policy (pp. 97-109). Ann Arbor: The University of Michigan Press. 
Lijphart, A. (1984). Democracies. Paterns of Majoritarian and Consensus Government in Twenty-One Countries. New Haven: Yale University Press.

Lijphart, A. (1999). Patterns of Democracy: Government Forms and Performance in Thirty-Six Countries. New Haven: Yale University Press.

Linz, J. J., \& Stepan, A. (1997). Toward Consolidated Democracies. In L. Diamond, M. F. Plattner, Y.-h. Chu, \& H.-m. Tien, Consolidating the Third Waves Democracies (pp. 14-33). Baltimore: The Johns Hopkins University Press.

Loada. (2003, Janvier 24). La limitation du nombres de mandats presidentiels en Afrique Francophone. Bordeau, Aquitaine, France.

Loada, A. (1999, décembre n 76 ). Réflexions sur la société civile en Afrique : Le Burkina de l'après-Zongo. Politique africaine , pp. 136-150.

Loada, A. (2003, Janvier 24). La limitation du nombres de mandats presidentiels en Afrique Francophone. 139(03). Bordeau, Aquitaine, France: Revue électronique Afrilex . Retrieved from http://afrilex.ubordeaux4.fr/sites/afrilex/IMG/pdf/3doc8loada.pdf

Loada, A. (2010). Constitutional Challenges and Lessons from Côte d'Ivoire, Guinea and Niger . In G. Gbesan, Democratic Recession in West Africa: Challenges to revivalism (pp. 45-62). Dakar: Amalion Publishing.

Loada, A., \& Ibriga, L. M. (2007). Droit constitutionel et institutions politiques. Ouagadougou: Imprimerie Presses Africaines.

Loada, A., Fall, I. M., \& Badet, G. (2008). Constitutionalism and Constitutional Amendments in West Africa: Case study of Benin, Burkina Faso and Senegal. Ouagadougou: Open Society in West Africa. 
Lorenz, A. (2005). How to measure Constitutional Rigidity. Journal of Theoretical Politics, 339-361.

Lutz, D. S. (1980). Popular consent and popular Control: Whig political Theory in the Early State Constitutions. Baton Rouge: Louisiana State University Press.

Lutz, D. S. (1988). The Origins of American Constitutionalism. Baton Rouge: Louisiana State University Press.

Lutz, D. S. (1994). Toward A Theory of Constitutional Amendment. The American Political Science Association, 88(2), 355-370.

Lutz, D. S. (2000). Thinking about Constitutionalism at the Start of the Twenty-First Century. Publius, 30(4), 115-135.

Macey, J. R. (1986). Promoting Public-regarding Legislation through Statory Interpretation: an Interest-group model. Columbia Law Review, 223-68.

Maltz, G. (2007, January). The Case for Presidential Term Limits. Journal of Democracy, $18(1), 128-142$.

Mattes, R., \& Thiel, H. (1999). Consolidation and Public Opinion in South Africa. In L. Diamond, \& M. F. Plattner, Democratization in Africa (pp. 123-139). Baltimore: The Johns Hopkins University Press.

May, J. C. (1997). Constitutional Amendments and Revision Revisited. New Developments in State Constitutional Law, 17(1), 153-179.

Mazza, M. J. (2003). A New Look at an Old Debate: Life Tenure and the Article III Judge. Gonzaga Law Review, 131-162.

Merryman, J. H. (1985). The Civil Law Tradition: An Introduction to the legal System of Western Europe and Latin America. Standford: Standford University Press. 
Merryman, J. H., \& Perez-Perdomo, R. (2007). The Civil Law Tradition: An introduction to the legal System of Europe and Latin America. Stanford: Stanford University Press.

Monga, C. (1999). Eight Problems with African Politics. In L. Diamond, \& M. F. Plattner, Democratization in Africa (pp. 48-62). Baltimore: The Johns Hopkins University Press.

Morel, L. (2007). The Rise of "Politically Obligatory" Referendums: The 2005 French Referendum in Comparative Perspective. West European Politics, 1041-1067.

Morgan, E. S. (1988). inventing the people: The Rise of Popular Sovereignty in England and America. New York: Norton.

Mueller, D. C. (1999). On Amending Constitutions. Constitutional Political Economy, 385-396.

Ndoye, D. (2001). La Constitution Senegalaise du 7 Janvier 2001 Commentee et ses Pactes internationaux annexes: les perspectives politiques, juridiques et sociales. Dakar: Editions Juridiques Africaines.

Ngenege, T. (2012, May 22). http://www.constitutionnet.org/country/constitutionalhistory-senegal. Retrieved from constitutionnet: http://www.constitutionnet.org/country/constitutional-history-senegal

Ngenge, T. (2010, september 5). http://www.constitutionnet.org/vl/item/lhistoireconstitutionnel-de-la-republique-du-senegal. Retrieved from constitutionnet: http://www.constitutionnet.org/vl/item/lhistoire-constitutionnel-de-la-republiquedu-senegal 
Nzouankeu, J. M. (1993). The role of the National Conference in the Transition to Democracy in Africa: the Cases of Benin and Mali. African Studies Association, 44-50.

O'Donnell, G. (1994). Illusions About Consolidation. In L. Diamond, M. F. Plattner, Y.h. Chu, \& H.-m. Tien, Consolidating the Third Waves Democracies (pp. 41-57). Baltimore: The Johns Hopkins Univeristy Press.

Ojwang, J. (1990). Constitutionalism in Classical Terms and in African Statehood. Losetho Law Journal, 57-74.

Okoth-Ogendo, H. (1993). Constitutions without Constitutionalism: Reflections on an African Paradox. In D. K. Greenberg, Constitutionalism and Democracy, Transitions in the Contemporary Wolrd. Toronto: Oxford.

Ottaway, M. (1995). Democratization in Collapsed States. In W. I. Zartman, Collapsed States: The Desintegration and Restauration of Legitimaate Authority (p. 246). Colorado: Boulder: Lynne Rienner.

Ouedraogo, S. M. (2011). La lutte contre la fraude à la constitution en Afrique Noire francophone. Bordeaux: Ecole doctorale de droit (Bordeaux).

Owona, J. (1985). L'Essor du Constitutionalisme, rédhibitoire en Afrique Noire: Etude de quelques Constitutions Janus. (P.-F. Gonidec, Ed.) Mélanges, 234-243.

Paine, T. (1956). The Rights Of Man. Oxford: Oxford University Press.

Panizza, U. (2001). Electorale rules, Political system, and institutional quality. Economics and Politics, 13, 311-342.

Peretti, T. J. (2002). Does Judicial Independence exists? In S. A. Friedman, Judicial independence at the Cross Roads (pp. 103-133). Tousand Oaks: Sage. 
Ponthoreau, M.-C., \& Hourquebie, F. (2009). The French Conseil Constitutionel: An Evolving Form of Constitutional Justice. In A. Harding, \& P. Leyland, Constitutional Courts: A Comparative study (pp. 81-101). London: Wildy ,Simmonds \& Hill Publishing.

Posner, D. N., \& Young, D. J. (2007). The Institutionalization of Political Power in Africa. Journal of Democracy, 18(3), 126-140.

Powe, L. A. (1998). Old People and Good Behavior. In W. N. Jr, \& S. Levinson, Constitutional Stupidities, Constitutional Tragedies (pp. 77-80). New York: New York University Press.

Prempeh, H. k. (2010). Presidents Untamed. In L. D. Plattner, Democratization in Africa: Progress and Retreat (pp. 18-32). Baltimore: The Johns Hopkins University Press.

Przeworski, A., Alvarez, M., Cheibub, J. A., \& Limongi, F. (1997). What Makes Democracies Endure. In L. Diamond, M. F. Plattner, \& a. H.-m. Yun-han Chu, Consolidating the Third Wave Democracies (pp. 295-311). Baltimore: The Johns Hopkins University Press.

Qvortrup, M. (2002). Comparative Study of Referendums : Government by the People. Manchester, New York: Manchester University Press.

RADDHO. (2001). Rapport sur L'observation du Referendum du 7 Janvier 2001. Dakar: Sicap Amitie II.

Rae, D. W. (1967). The Political Consequences of Electoral Laws. New Haven: Yale University Press. 
Reynjens, f. (1991). The Winds of Change. Political and Constitutional Evolution in Francophone Africa (1990-1991). Journal of African Law, 35(1/2), 44-55.

Riker, W. H. (1982). Liberalism against populism. Prospect Heights, Il: Waveland Press.

Robert, j. H., \& Rosberg, C. G. (1984, July). Personal Rule: Theory and Practice in Africa. Comparatives Politics, 16(4), 421-442.

Roberts, A. (2006). What kind of democracy is emerging in eastern Europe? Post-Soviet Affairs(21), 37-64.

Roberts, A. (2009). The politics of constitutional amendments in postcommunist Europe. Constitutional Political Economy, 99-117.

Robinson, P. T. (1994). The National Conference Phenomenon in Francophone Africa . Comparative Studies in Society and History, 575-610.

Rotman, A. (2004). Benin's Constitutional Court : An Institutional Model for Guaranteeing Human Rights. Harvard Human rights Journal , 281-314.

Russell, P. H. (2001). Toward a General Theory of Judicial Independence. In P. H. O'Brien, Judicial Independence in the Age of Democracy (pp. 1-24). Charlottesville: University Press of Virginia.

Salami, A. I. (2005). La protection de l'état de droit par les cours constitutionnelles africaines : analyse comparative des cas béninois, ivoirien, sénégalais et togolais. Thèse pour obtenir le grade de docteur en droit public, université François Rabelais de Tours, so. Lille: Atelier National de Reproduction des Theses.

Santiso, C. (1998). Case Study: National Conferences in Francophone Africa. In P. H. Reilly, Democracy and Deep-Rooted Conflict: Options for Negotiators (pp. 262272). Stockholm: International IDEA. 
Santiso, C., \& Loada, A. (2003). Explaining the Unexpected: Electoral Reform and Democratic Governance in Burkina Faso. The Journal of Modern African Studies, 395-419.

Santori, G. (1989). Comparative constitutional Engineering. London: Macmillan.

Sartori, G. (1976). Parties and Party system: A framework for Analysis. Cambridge : Cambridge University Press.

Scales-Trent, J. (2011). Presidential Authority and the 2001 Constitution of Senegal. North Carolina Central Law Review, 81-97.

Seely, J. C. (2009). The Legacies of Transition Government in Africa: the Case of Benini and Togo. New York: Palgrave Macmillan.

Segal, J. A., Spaeth, H. J., \& Benesh, S. C. (2005). The Supreme Court in the American Legal System. New York: Cambridge University Press.

Shapiro, M. (1981). Courts: A Comparative and Political analysis. Chicago: The University of Chicago Press.

Sklar, R. L., Onwudiwe, E., \& Kew, D. (2006, July). Nigeria: Completing Obasanjo's Legacy. Journal of Democracy, 17(3), 100-115.

Smith, G. (1976). 'The Functional Properties of The Referendums'. European Journal of Political Research, 6.

Staffan, I. L. (1969, January). The Surprising Significance of African Elections. Journal of Democracy, 17(1), 139-151.

Staffan, I. L. (2009). Democratization by Election: A New Mode of Transition. Baltimore: The John Hopkings University Press. 
Steven, J. P. (1984). Reflections on the Removal of Sitting Judges. Stetson Law Review, 13(2), 215-220.

Stras, D. R., \& Scott, R. W. (2006). Retaining Life Tenure: The case for a "Golden Parachute". Washington University Law Quaeterly, 1397-1467.

Sturn, L. A. (1970). Thirty Years of State Constitution-Making 1938-1968. New York: National Municipal League.

Suksi, M. (1993). Bringing In the People: A comparison of Constitutional Forms and Practices of the Referendum. Dordrecht: Martinus Nijhoff Publishers.

Suksi, M. (1995). Making a constitution: the outline of an argument. Abo: Åbo Akademis kopieringscentral.

Tama, J. N. (2009, Avril-Juin). La Constitution Beninoise du 11 Decembre 1990 a l'epreuve du Temps: sa revision, une opportunite politique ou juridique. Revue Juridique et Politique des Etats Francophones, 63(2), 149-176.

Thiam, A. (2007). «Une Constitution, ça se révise ! ». Relativisme constitutionnel et État de droit au Sénégal . Politique Africaine, 145-153.

Thomas, M. A., \& Sissokho, O. (2005). The Role of the National Assembly in Senegal. The Journal of Modern African Studies, 97-117.

Tushnet, M. (2008). Comparative Constitutional Law. In R. D. Keith E. Whittington, The Oxford Hanbook of Law and Politics (pp. 1225-1257). New York: Oxford University Press.

Vile, J. R. (1992). The Constitutional amendment process in American political Thought. New York: Praeger Publisher. 
Viscount, J. B. (1901). Flexible and Rigid Constitutions. In V. James Bryce, Studies in History and Jurisprudence, vol. 1 [1901]. New York: Oxford University Press.

Volcansek, M. L. (2007). Appointing Judges the European Way. The Fordham urban law journal, 34(1), 360-386.

Walle, N. V. (2003). Presidentialism and Clientelism in Africa's Emerging Party System. Journal of Modern African Studies, 297-321.

Walle, N. V. (2009). Democratization en Afrique: un bilan critique. In M. Gazibo, \& C. Thiriot, La Politique en Afrique: Etats des débats et pistes de recherches (pp. 135-163). Paris: Karthala.

Wantchekon, L. (2003). Clientelism and Voting Behavior: Evidence from a Field Experiment in Benin. World Politics, 399-422.

Widner, J. (2005, August 06/11/2011). Constitution Writing and Conflict Resolution. Retrieved from Constitution Writing \& Conflict Resolution: Data \& Summaries first posted 2005 and accessed at [URL above] on [date accessed: http://www.princeton.edu/ pcwcr/about/copyright.html

William and Mary Law Review. (2008). Constitutional drafting in Post-conflict states symposium (Vol. 49). (A. W. Scott, Ed.) Williamsburgh, VA: Western Publishing Company.

Yameogo, H. (1990). Un supplement d'ame pour une société consensuelle. Koudougou: BBDA.

Ye, B. A. (1995). Burkina Faso, les fondements politiques de la IVe Republique. Ouagadougou: Press Universitaire de Ouagadougou.

Zakaria, F. (1997). The Rise of Illiberal Democracy. Foreign Affairs, 22-43. 
Zarka, J.-C. (1996). Les systemes électoraux. Paris: Ellipses.

Zoethout, C. M., Pietermaat-Kros, M. E., \& Akkermans, P. W. (1996). Constitutionalism in Africa: A quest for autochtonous principles. Rotterdam: Sanders Institute. 